\begin{tabular}{|c|c|c|}
\hline $\begin{array}{ll}\text { sta } & 15 \\
\text { JU1 } 02 & 1999\end{array}$ & ENGINEERING DATA TRANSMITTAL & $\begin{array}{r}\text { Pago } 1 \text { of } \frac{1}{1} \\
\text { 1. EDT } 6263311\end{array}$ \\
\hline
\end{tabular}

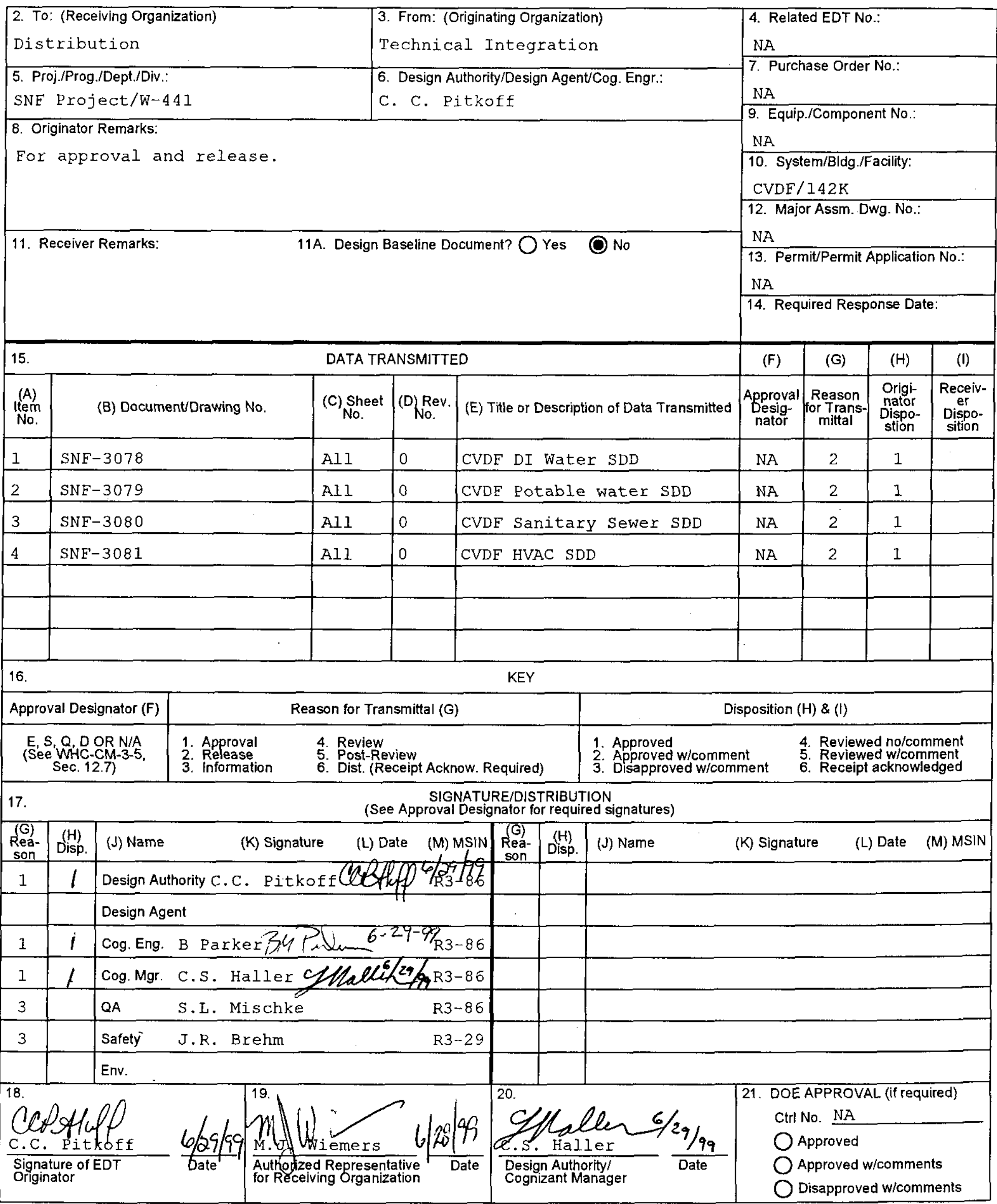




\section{Cold Vacuum Drying Facility HVAC System Design Description}

\section{C. Pitkoff}

DE\&S Hanford,

Richland, WA 99352

U.S. Department of Energy Contract DE-AC06-96RL13200.

EDT/ECN: 6263 (1) OMB \&(3994) UC: 510

Org Code: $2 \mathrm{~F} 800$

CACN: 105568

COA: A000

B\&R Code: 39EW70400

Total Pages: 101 (JLBG/30/99)

Key Words: SNF, CVD, W-441, design description, HVAC, air, process exhaust, general supply, general exhaust, reference air, local exhaust

Abstract: This document describes the Cold Vacuum Drying Facility (CVDF) heating, ventilation, and air conditioning system (HVAC). The CVDF HVAC system consists of the Administrative building HVAC system, the process bay recirculation HVAC system, the process bay local HVAC and process vent system, the process general supply/exhaust HVAC system, and the Reference air system. These HVAC sub-systems support the CVDF process and provide secondary confinement of contamination and the required filtration of exhaust.

TRADEMARK DISCLAIMER. Reference herein to any specific commercial product, process, or service by trade name, trademark, manufacturer, or otherwise, does not necessarily constitute or imply its endorsement, recommendation, or favoring by the United States Government or any agency thereof or its contractors or subcontractors.

Printed in the United States of America. To obtain copies of this document, contact: Document Control Services, P.0. Box 950, Mailstop H6-08, Richland WA 99352. Phone (509)

372-2420: Fax (509) 376-4989.
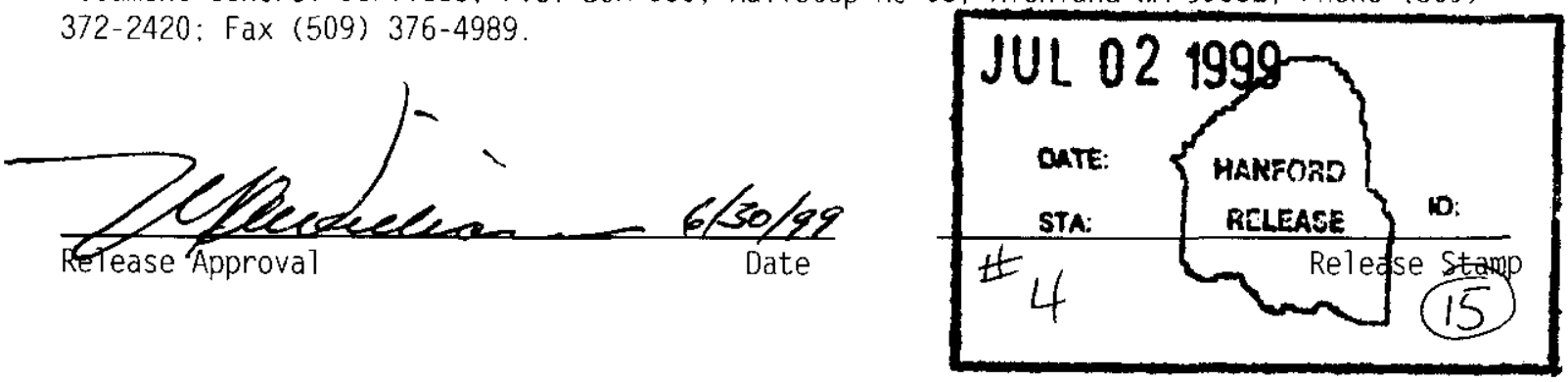
SNF-3081 Rev. 0

COLD VACUUM DRYING FACILITY

HEATING, VENTILATION, AND AIR CONDITIONING SYSTEM DESIGN DESCRIPTION

SYSTEMS 30-1 THROUGH 30-5 


\section{TABLE OF CONTENTS}

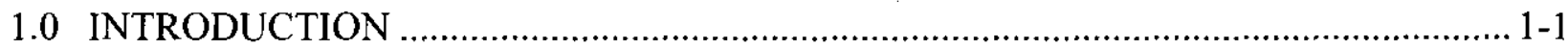

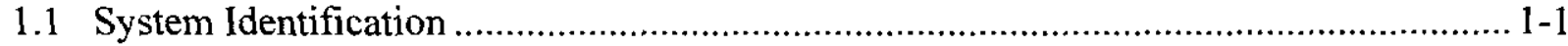

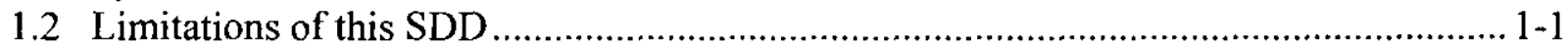

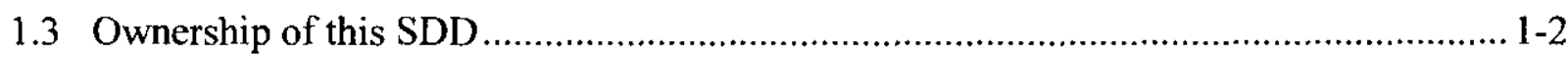

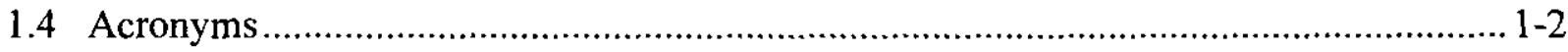

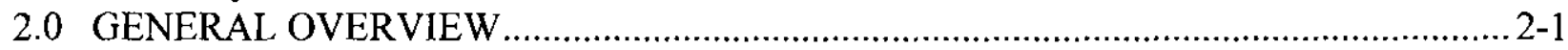

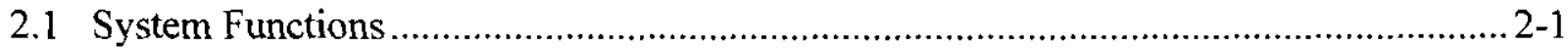

2.1.1 Administration Building HVAC System .......................................................2-1

2.1.2 Process Bay Recirculation HVAC System .....................................................2-2

2.1.3 Process Bay Local Exhaust HVAC and Process Vent System ................................ 2-2

2.1.5 Reference Air System ................................................................................. 2-4

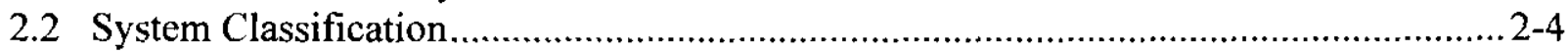

2.2.1 Administration Building HVAC System ......................................................... 2-4

2.2.2 Process Bay Recirculation HVAC System ………............................................... 2-4

2.2.3 Process Bay Local Exhaust HVAC and Process Vent System............................... 2-5

2.2.4 Process General Supply/Exhaust HVAC System .................................................. 2-5

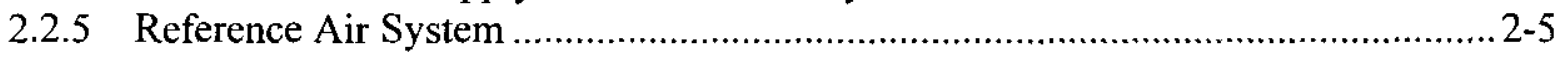

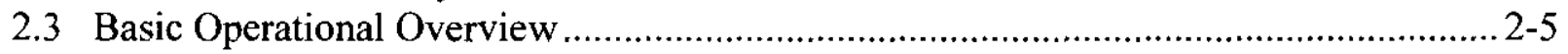

2.3.1 Administration Building HVAC System ...................................................... 2-11

2.3.2 Process Bay Recirculation HVAC System .....................................................2-11

2.3.3 Process Bay Local Exhaust HVAC and Process Vent System ............................ 2-11

2.3.4 Process General Supply/Exhaust HVAC System …………................................22-11

2.3.5 Reference Air System .............................................................................. 2-11

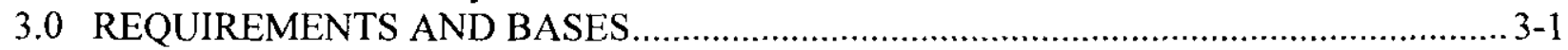

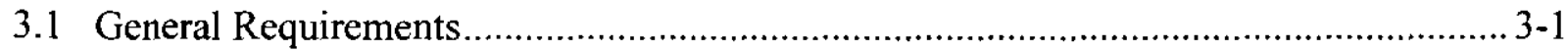

3.1.1 System Functional Requirements ................................................................. 3-1

3.1.2 Subsystem and Major Components ……………........................................... 3-16

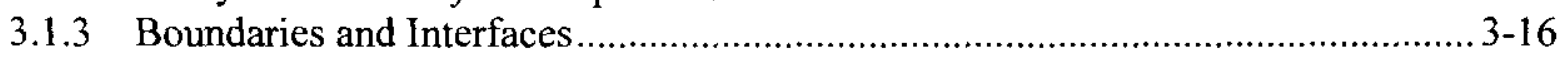

3.1.4 Codes, Standards, and Regulations ............................................................. 3-17

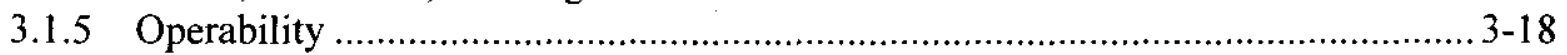

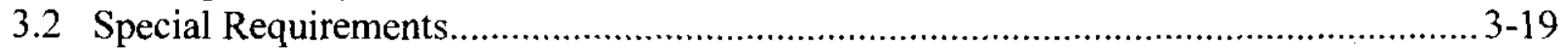

3.2.1 Radiation and Other Hazards .................................................................... 3-19

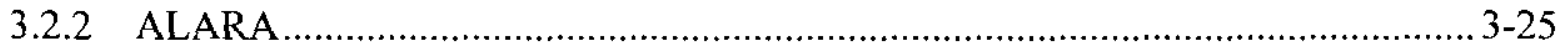

3.2.3 Nuclear Criticality Safety .......................................................................... 3-27

3.2.4 Industrial Hazards ....................................................................................... 3-27

3.2.5 Operating Environment and Natural Phenomena ……......................................... 3-27

3.2.6 Human Interface Requirements ................................................................... 3-27

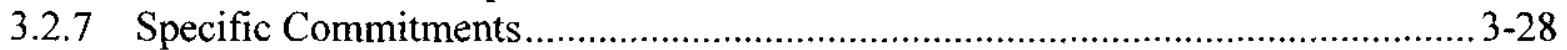

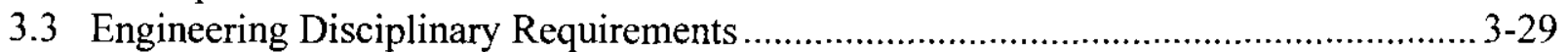

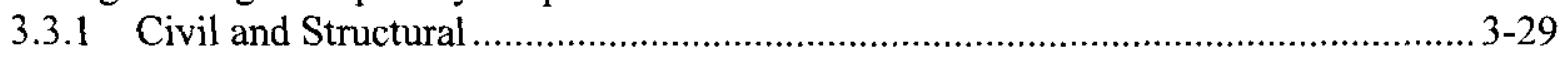

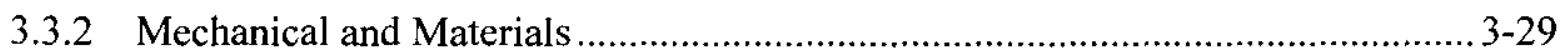

3.3.3 Chemical and Process ............................................................................... 3-34

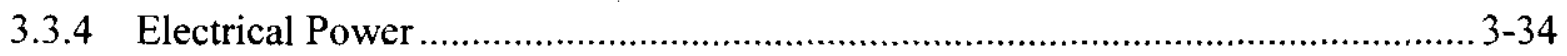

3.3.5 Instrumentation and Control ........................................................................... 3-34 
3.3.6 Computer Hardware and Software ............................................................... 3-35

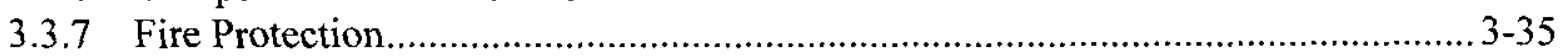

3.4 Testing And Maintenance Requirements....................................................... 3-37

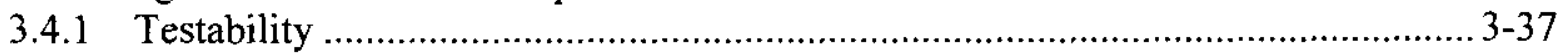

3.4.2 Technical Safety Requirement-Required Surveillances ................................. 3-38

3.4.3 Non-Technical Safety Requirement Inspections and Testing ............................ 3-38

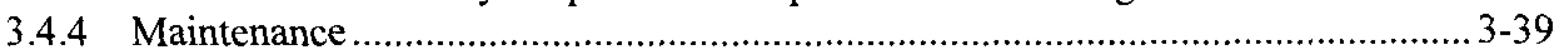

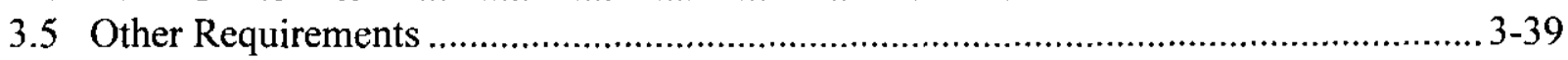

3.5.1 Security and Special Nuclear Material Protection ...........................................3-39

3.5.2 Special Installation Requirements.......................................................... 3-39

3.5.3 Reliability, Availability, and Preferred Failure Modes..................................... 3-39

3.5.4 Quality Assurance ................................................................................... 3-40

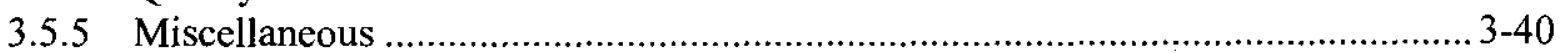

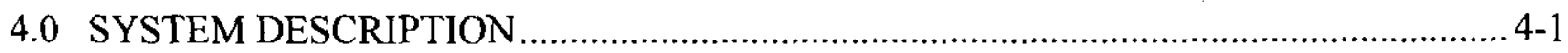

4.1 Configuration ................................................................................................. 4

4.1.1 Description of System, Subsystems, and Major Components ............................ 4-1

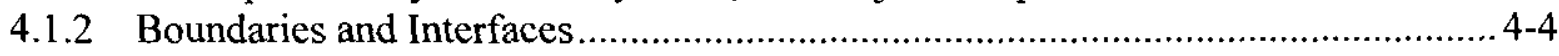

4.1.3 Physical Location and Layout.................................................................... 4-11

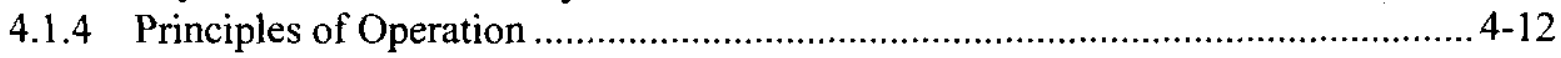

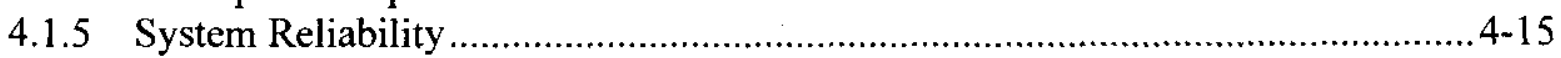

4.1.6 System Control Features ........................................................................ 4-16

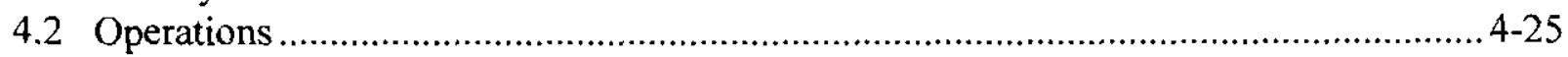

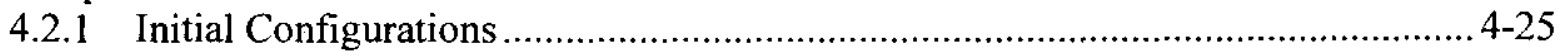

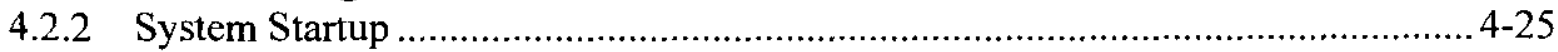

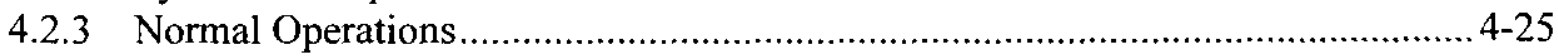

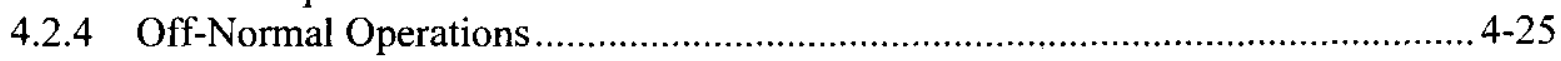

4.2.5 System Shutdown .............................................................................. 4-25

4.2.6 Safety Management Programs and Administrative Controls............................... 4-25

4.3 Testing And Maintenance ........................................................................... 4-25

4.3.2 Technical Safety Requirement-Required Surveillances ................................... 4-25

4.3.3 Non-Technical Safety Requirement Inspections and Testing ............................ 4-25

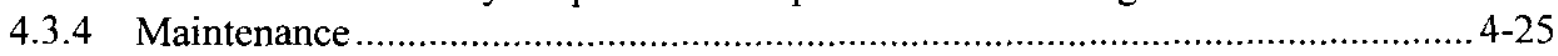

APPENDIX A. Source Documents........................................................................... A

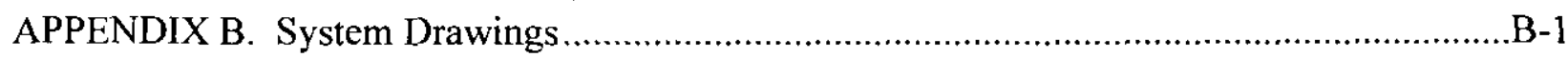

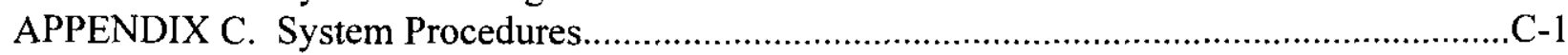

APPENDIX D. Miscellaneous Information.................................................................. D-1 


\section{LIST OF FIGURES}

Figure 1-1. HVAC General Arrangement ......................................................................... 1-3

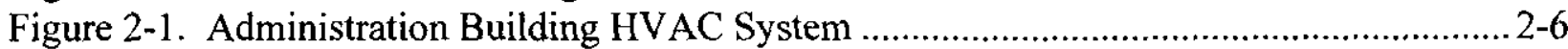

Figure 2-2. CVD Facility Process Bay Recirculation HVAC System .................................... 2-7

Figure 2-3. CVD Facility Process Bay Local Exhaust HVAC and Process Vent System......... 2-8

Figure 2-4. CVD Facility Process General Supply/Exhaust HVAC System............................2-9

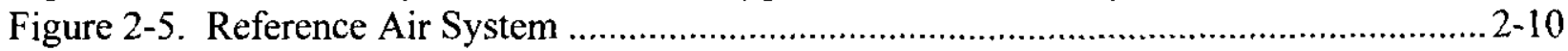

Figure 4-1. Administration Building - HVAC System ................................................... 4-2

Figure 4-2. Process Bay Recirculation - HVAC System ................................................... 4-3

Figure 4-3. Process Bay Local Exhaust HVAC and Process Vent System ............................. 4-5

Figure 4-4. Process General Supply Exhaust - HVAC System ............................................ 4-6

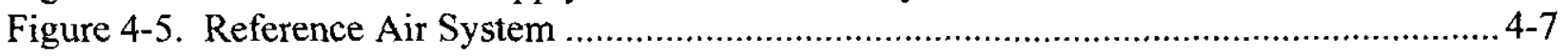

\section{LIST OF TABLES}

Table 3-1. Codes, Standards, and Source Documents that Apply to Cold Vacuum Drying

Facility Piped System .................................................................................. 3-34

Table 4-1. Pressure Transmitter/Indicator Parameters and Setpoints ................................... 4-22

Table 4-2. Temperature Transmitter Parameters and Setpoints.......................................... 4-23

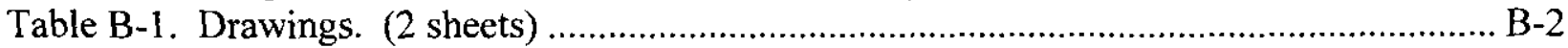

Table B-2. Specification List. ....................................................................................... B-3 


\subsection{INTRODUCTION}

\subsection{System Identification}

This system design description (SDD) addresses the HVAC system for the CVDF. The CVDF HVAC system consists of five subsystems:

- Administration building HVAC system

- $\quad$ Process bay recirculation HVAC system

- $\quad$ Process bay local exhaust HVAC and process vent system

- Process general supply/exhaust system

- Reference air system

The HVAC and reference air systems interface with the following systems: the fire protection control system, Monitoring and Control System (MCS), electrical power distribution system (including standby power), compressed air system, Chilled Water (CHW) system, drainage system, and other cold vacuum drying (CVD) control systems not addressed in this SDD.

See Figure 1.1, HVAC General Arrangement, for the general arrangement of the HVAC system.

\subsection{Limitations of this SDD}

This SDD, when used in conjunction with the other elements of the definitive design package, provides a complete picture of the HVAC system for the CVD Facility. Elements of SDD include functions, requirements, and descriptions. Other documents comprising the definitive design include:

- $\quad$ Project design requirements (HNF-SD-SNF-DRD-002),

- $\quad$ Fire Hazard Analysis (HNF-SD-SNF-FHA-003),

- Master Equipment List (SNF- 4148),

- Data and calculation matrix tracking list (SNF-3001),

- Construction Specification for Project W-441, Section 15400, Plumbing/Piping.

This SDD revision was prepared to support the CVDF FSAR submittal to the DOE. The FSAR is a higher-level document than this SDD. HVAC requirements that change due to DOE review will be incorporated into this SDD in later revisions. In addition, specific HVAC operating characteristics (determined from system testing) and specific operating procedures (when written) will be incorporated and referenced in this SDD in later revisions. 


\subsection{Ownership of this SDD}

The CVD Design Authority assigned to the HVAC system is responsible for the accuracy and technical content of this SDD. Any questions on the system or content of this document shall be resolved through the design authority.

\subsection{Acronyms}

ALARA as low as reasonably achievable

ANSI

ASME

CFR

CVD

CVDF

DBA

DPIT

HEPA

HVAC

IA

MCO

MCS

PCV

PES

psig

PWC

SAR

scfm

SNF

SRV

SSC

TBD
American National Standards Institute

American Society of Mechanical Engineers

Code of Federal Regulations

Cold Vacuum Drying

Cold Vacuum Drying Facility

Design Basis Accident

Differential Pressure Instruments

High-Efficiency Particulate Air (filter)

Heating, Ventilation, and Air Conditioning

Instrument Air (system)

Multi-Canister Overpack

Monitoring and Control System

Pressure Control Valve

Process Equipment Skid

pounds per square inch gauge

Process Water Conditioning (system)

Safety Analysis Report

cubic feet (at standard temperature and pressure) per minute

Spent Nuclear Fuel

Safety Relief Valve

Structure, System, and Component

To Be Determined 
Figure 1-1. HVAC General Arrangement

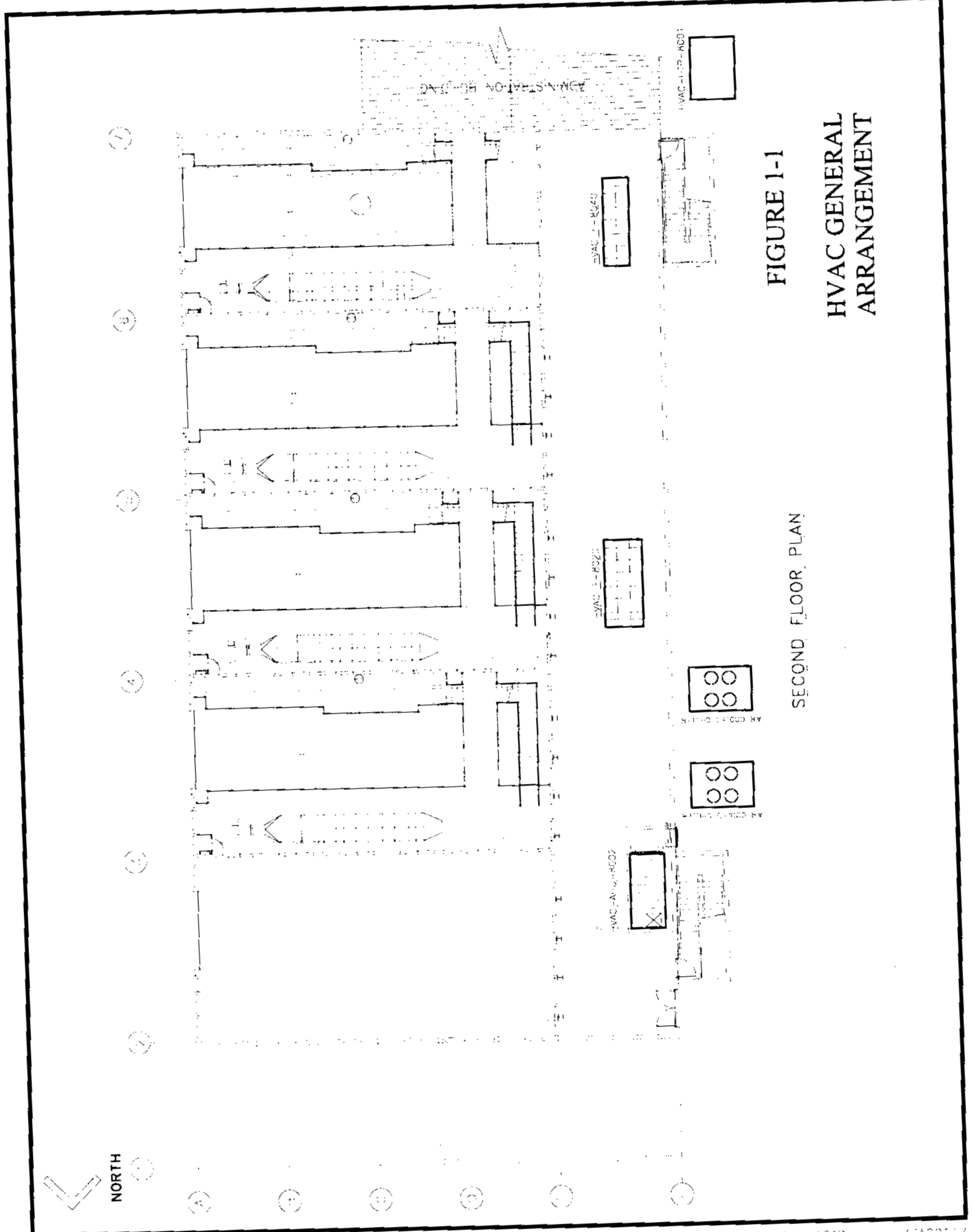

BEST AVAILABLE COPY 
SNF-3081 Rev. 0

\subsection{GENERAL OVERVIEW}

\subsection{System Functions}

The CVDF design includes the following five HVAC systems:

- Administration Building HVAC System

- $\quad$ Process Bay Recirculation HVAC System

- Process Bay Local Exhaust HVAC and Process Vent System

- Process General Supply/Exhaust HVAC System

- Reference Air System

Two HVAC systems, the process bay local exhaust HVAC and process vent system and process general supply/exhaust HVAC system, provide airborne radioactive material confinement within the radiologically controlled areas of the CVDF and provide HEPA-filtered discharge via the CVDF stack. Each process bay also has an independent process bay recirculation HVAC system that provides outside air supply and HEPA-filtered recirculation for heating and air-conditioning. The humidity is monitored in all HEPA-filtered ventilation systems, and a humidity sensor alarms in the control room on high humidity. The CVDF administrative building has an independent supply and exhaust HVAC system that operates at a positive pressure to preclude inleakage from outside or adjacent areas.

All exhaust systems function during normal operation. Monitoring of the differential pressure, between a reference air system and building locations, facilitates maintaining confinement in the facility except when the telescoping door to a process bay is opened. The HVAC systems utilize isolation dampers to stop the flow of air to maintain confinement within the facility and preclude cross-contamination between areas during upset conditions.

The CVDF has been designated as a hazard category 2 nuclear facility.

The safety functions listed in this section are consistent with the safety functions listed in Chapter 4 of the CVDF Final Safety Analysis Report (FSAR). The safety functions are incorporated into the design of the system by defining related functional requirements in Section 3.1 .6

\subsubsection{Administration Building HVAC System}

2.1.1.1 General Function. The administration building HVAC system functions to provide HVAC to the administrative and control room areas of the facility, maintaining working areas within the administration building at a comfortable temperature. The system also keeps the 
administration building at a positive pressure relative to the CVDF transfer corridor to prevent possible contamination ingress into the administrative building.

2.1.1.2 Safety Function. There are no safety functions listed in Chapter $4 \mathrm{HNF}-3553$, Rev. 0 (FSAR) for the administration building HVAC system.

\subsubsection{Process Bay Recirculation HVAC System}

2.1.2.1 General Function. The process bay recirculation HVAC system provides conditioned air to the process bays to meet the air quality and comfort conditions set forth in the design requirements. The air is filtered and heated/cooled upon recirculation. Make-up air is prefiltered and supplied to maintain air quality in the process cells.

2.1.2.2 Safety Function. The process bay recirculation HVAC system supply isolation dampers at each process bay must fail closed upon facility loss of power to enable the process bay local exhaust HVAC and process vent system operating on standby power to maintain differential pressure in the process bays. This is applicable for the gaseous release, MCO internal hydrogen explosion, MCO external hydrogen explosion, and MCO overpressurization accidents.

\subsubsection{Process Bay Local Exhaust HVAC and Process Vent System}

2.1.3.1 General Functions. The role of the process bay local exhaust HVAC and process vent system is to provide protection to onsite personnel by removing any contamination discharged by the process vents or through the MCO connections on the hood and filtering it prior to release to the environment. The following process areas in each of the four bays are exhausted by the local exhaust system:

- Transfer cask top hood

- $\quad$ Process vests on

$\begin{array}{ll}- & \text { Vacuum pump exhaust } \\ - & \text { Vacuum Purge system (VPS) condenser tank } \\ - & \text { Process Water Conditioning (PWC) tank vent } \\ - & \text { Tempered Water (TW) system tank vent } \\ -\quad & \text { Safety-Class Helium (SCHe) system vent }\end{array}$

2.1.3.2 Safety Functions. The process bay local HVAC and process vent system performs the following safety functions to prevent or mitigate safety significant consequences from the bounding accident scenarios.

- Provides confinement of radioactive material released within the process bay during processing operations. The system's operation mitigates the radioactive release from the CVDF after the gaseous release, MCO external hydrogen explosion, MCO internal hydrogen explosion, and MCO overpressurization accidents by directing the flow from the process bays through ductwork to the HEPA filters, prior to discharge from the facility. The hood isolation dampers fail closed and are provided with a instrument air 
reservoir for operation on standby power. The local exhaust system fans can restart with standby power and can maintain a process bay differential pressure when the process general supply/exhaust HVAC system is not operable (e.g., facility loss of electrical power).

- Maintains local exhaust flow sufficient to dilute potentially hydrogen-rich process gas discharges into the local exhaust duct to preclude flammable mixtures from being generated. Its operation prevents an external hydrogen explosion accident by diluting hydrogen gas from the process vent lines and directing the flow from the process bays through ductwork to HEPA filters prior to discharge from the facility for external and internal hydrogen explosion, thermal runaway, and MCO overpressurization accidents. The $30 \mathrm{lb} / \mathrm{in}^{2}$ gauge vent line discharge as a result of the MCO overpressurization accident is also adequately diluted by the local exhaust flow. The hood isolation dampers fail closed on loss of power. The local exhaust system can restart with standby power and can reestablish local exhaust flow within 1 minute, sufficient to dilute potentially hydrogen-rich process gas discharges into an exhaust duct and maintain a process bay differential pressure when the process general supply/exhaust HVAC system is not operable (i.e., facility loss of electrical power). The local exhaust provides a process hood low-flow alarm to the control room to preclude cask venting with inadequate dilution flow. The local exhaust also provides the cask venting connection with a flow-restricting orifice, along with a shut-off valve interlocked to a local exhaust low-flow switch for each bay.

\subsubsection{Process General Supply/Exhaust HVAC System}

2.1.4.1 General Function. The process general supply/exhaust HVAC system provides conditioned air to the CVDF process bays and transfer corridor areas. The system controls exhaust airflow to maintain a minimum negative pressure differential in the process bays and the PWC tank room.

2.1.4.2 Safety Functions. The process general supply/exhaust HVAC system performs the following safety functions to mitigate safety-significant consequences from the bounding accident scenarios. Only the exhaust portion of the system is credited with mitigation (HEPA filtration) and maintenance of differential pressure to accomplish confinement.

- The process general exhaust system provides confinement of radioactive material within the process bays and process water tank room during processing operations if a release from primary confinement occurs. Its operation mitigates the radioactive release from the CVDF after the gaseous release, liquid release, MCO external hydrogen explosion, MCO internal hydrogen explosion, and MCO overpressurization accidents (identified in the FSAR Table B4-8) by maintaining a negative pressure in the process bays and process water tank room during facility operations, as indicated in Table B4-8, and by HEPA filtering the building air prior to discharge from the facility.

- The process general exhaust isolation dampers at each process bay must fail closed upon facility loss of power to provide confinement and prevent cross contamination. This 
functional requirement is applicable for the gaseous release, MCO external hydrogen explosion, MCO internal hydrogen explosion, and MCO overpressurization accidents.

\subsubsection{Reference Air System}

2.1.5.1 General Functions. The role of the reference air system is to provide atmospheric pressure air to each of 13 differential pressure transmitters located in different rooms of the CVDF.

2.1.5.2 Safety Functions. The reference air system performs the following safety functions to mitigate safety-significant consequences from the bounding accident scenarios.

- The process bay and process water tank room differential pressure alarms provide a safety-significant function for mitigation of the consequence of gaseous release, liquid release, MCO external hydrogen explosion, $\mathrm{MCO}$ internal hydrogen explosion, and $\mathrm{MCO}$ overpressurization accidents. The alarm notifies personnel of the loss-of-confinement function, and personnel initiate appropriate action to preclude releases during the abnormal confinement condition. This requirement to demonstrate HVAC confinement function related to location and DBA is summarized in the FSAR Table B4-8.

- The system must provide a reliable reference air signal to the process bay and process water tank room differential pressure indicators with low differential pressure alarms so they can perform their safety-significant function.

\subsection{System Classification}

\subsubsection{Administration Building HVAC System}

The administration building HVAC system is classified as general service, Performance Category 1 per DOE Order 1020.

\subsubsection{Process Bay Recirculation HVAC System}

The process bay recirculation HVAC system is classified as general service. The only portions of the process bay recirculation HVAC system that performs a safety-significant function are the fail-closed inlet isolation dampers. The general service portion must meet the requirements of Performance Category 1, while the safety significant portion must meet the requirements of Performance Category 2. 


\subsubsection{Process Bay Local Exhaust HVAC and Process Vent System}

The Process Bay Local Exhaust HVAC and Process Vent System is classified as safetysignificant due to its role in preventing or mitigating safety-significant consequences from bounding accident scenarios described in Section 2.1.3.2 These components meet the criteria of Performance Category 2.

\subsubsection{Process General Supply/Exhaust HVAC System}

The supply portion of the general supply/exhaust HVAC system is classified as general service. The exhaust portion of the system, from isolation dampers to filter housing, are classified as safety-significant due to its mitigation (HEPA filtration) and maintenance of differential pressure to accomplish confinement. The general service portion must meet the requirements of Performance Category 1, while the safety significant portion must meet the requirements of Performance Category 2.

\subsubsection{Reference Air System}

Differential pressure indication for HVAC control is considered general service and is provided in conjunction with the reference air system and monitored by the automatic temperature control system. Safety-significant DPITs with low differential pressure alarms to the control room are also provided. The reference air header is also safety-significant to provide a reliable reference air signal to the differential pressure alarms. The alarm will initiate operator action if process or HVAC changes must be initiated based on confinement status. The general service portion must meet the requirements of Performance Category 1, while the safety significant portion must meet the requirements of Performance Category 2.

\subsection{Basic Operational Overview}

The following sections provide a basic operational overview of each individual system within the CVDF HVAC system. Figures 2-1 through Figure 2-5 provide general overviews of each system. 


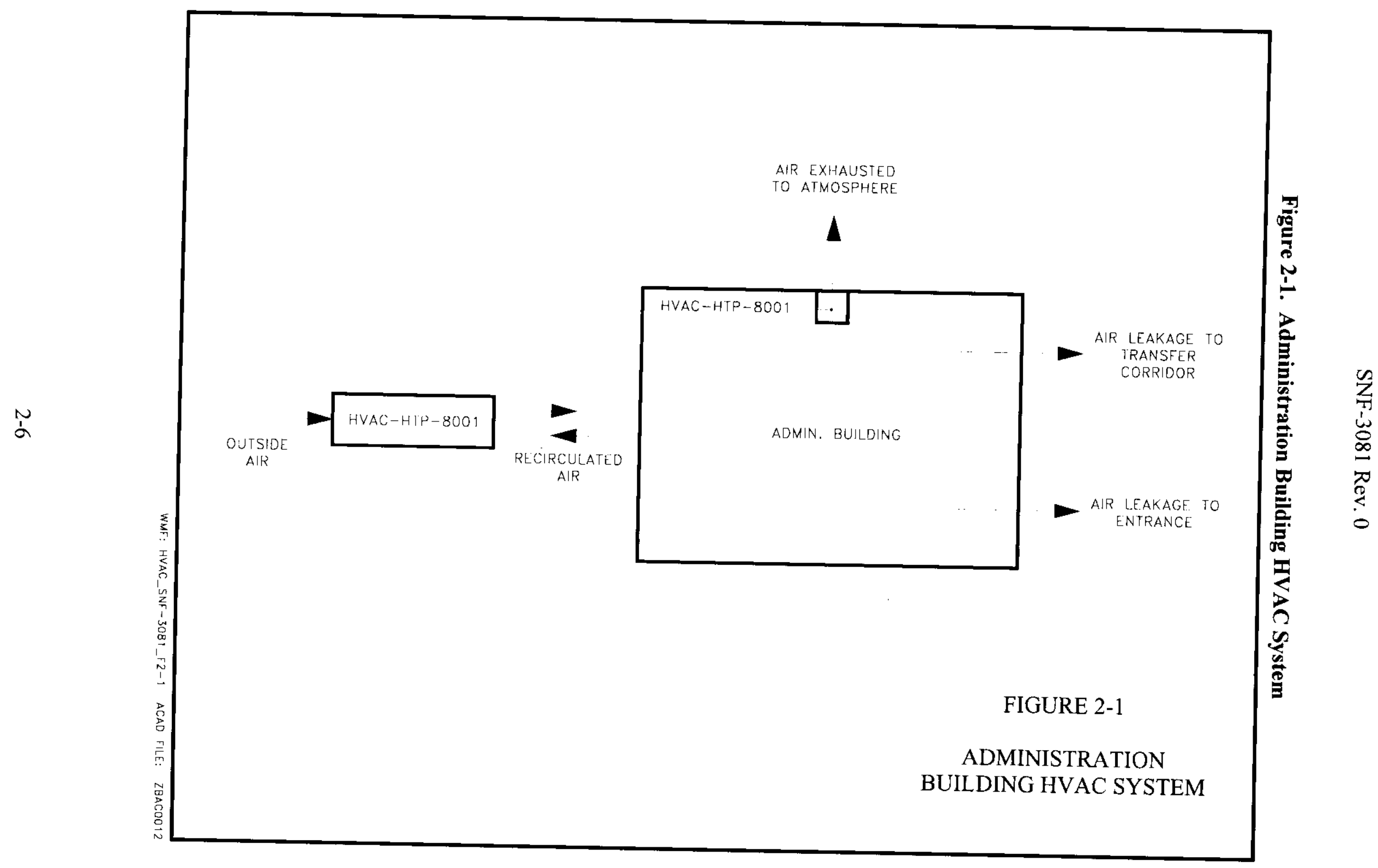


SNF-3081 Rev. 0

Figure 2-2. CVD Facility Process Bay Recirculation HVAC System

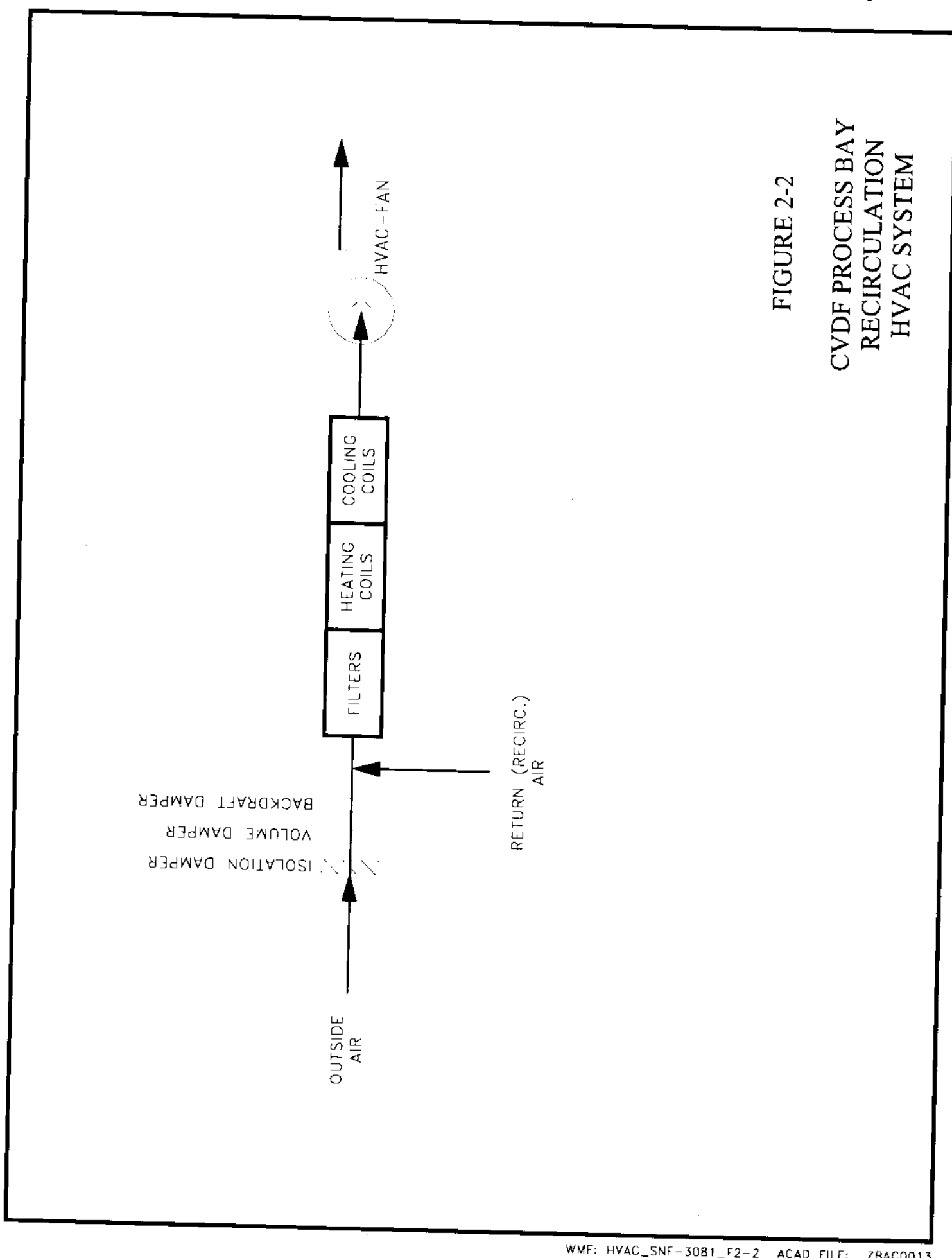

WMF: HVAC_SNF-3081_F2-2 ACAD FILE: ZBACO013 
Figure 2-3. CVD Facility Process Bay Local Exhaust HVAC and Process Vent System

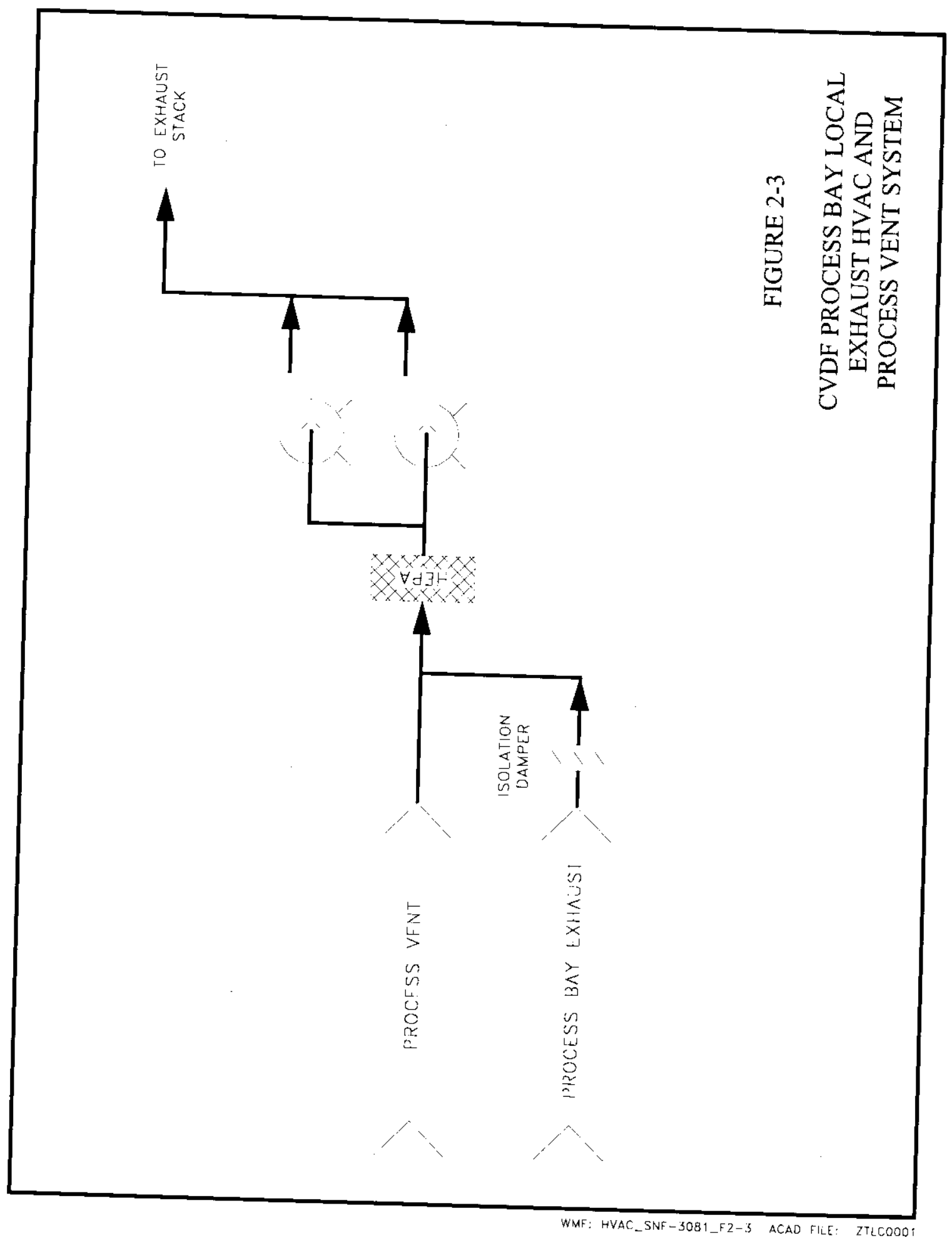




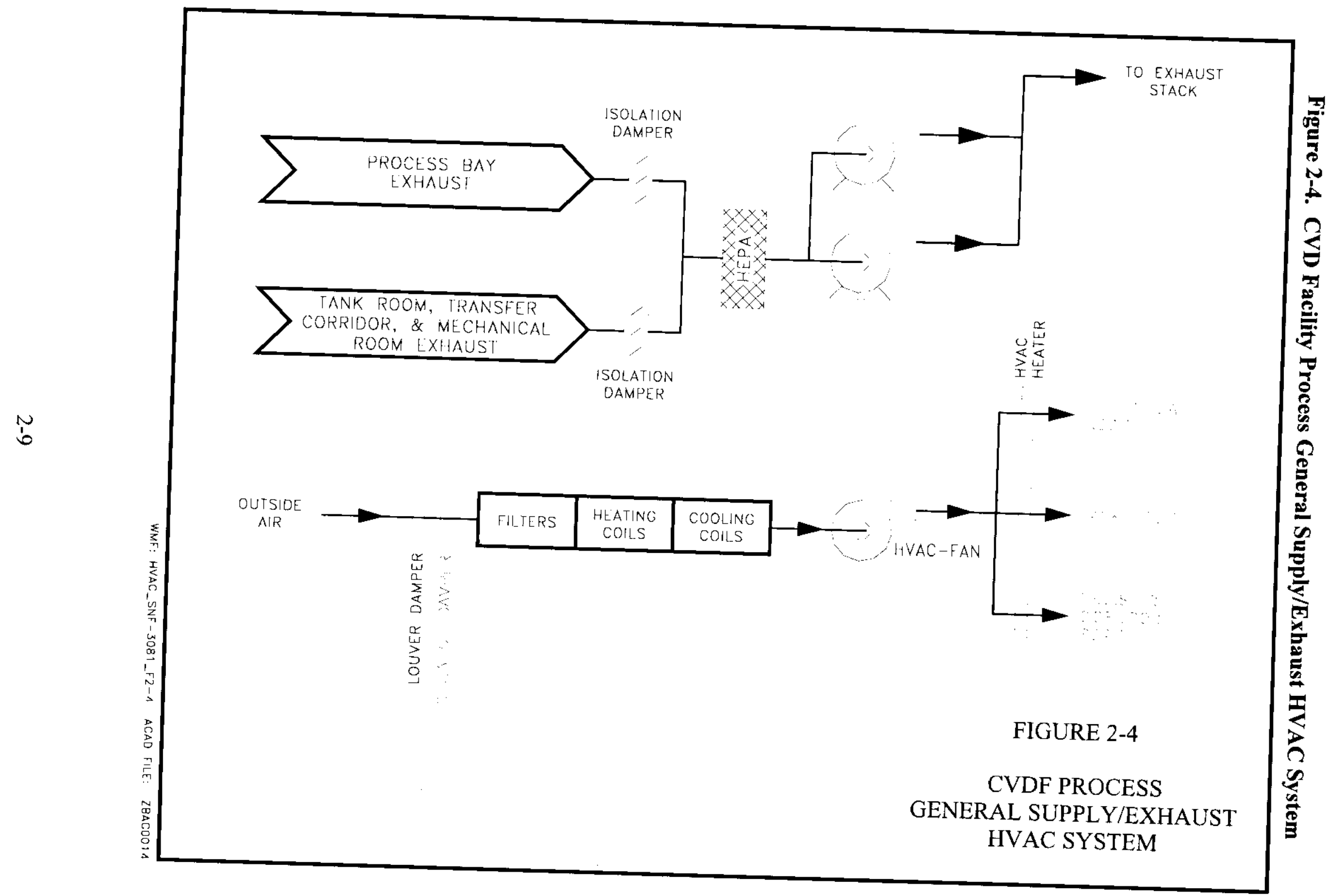


Figure 2-5. Reference Air System

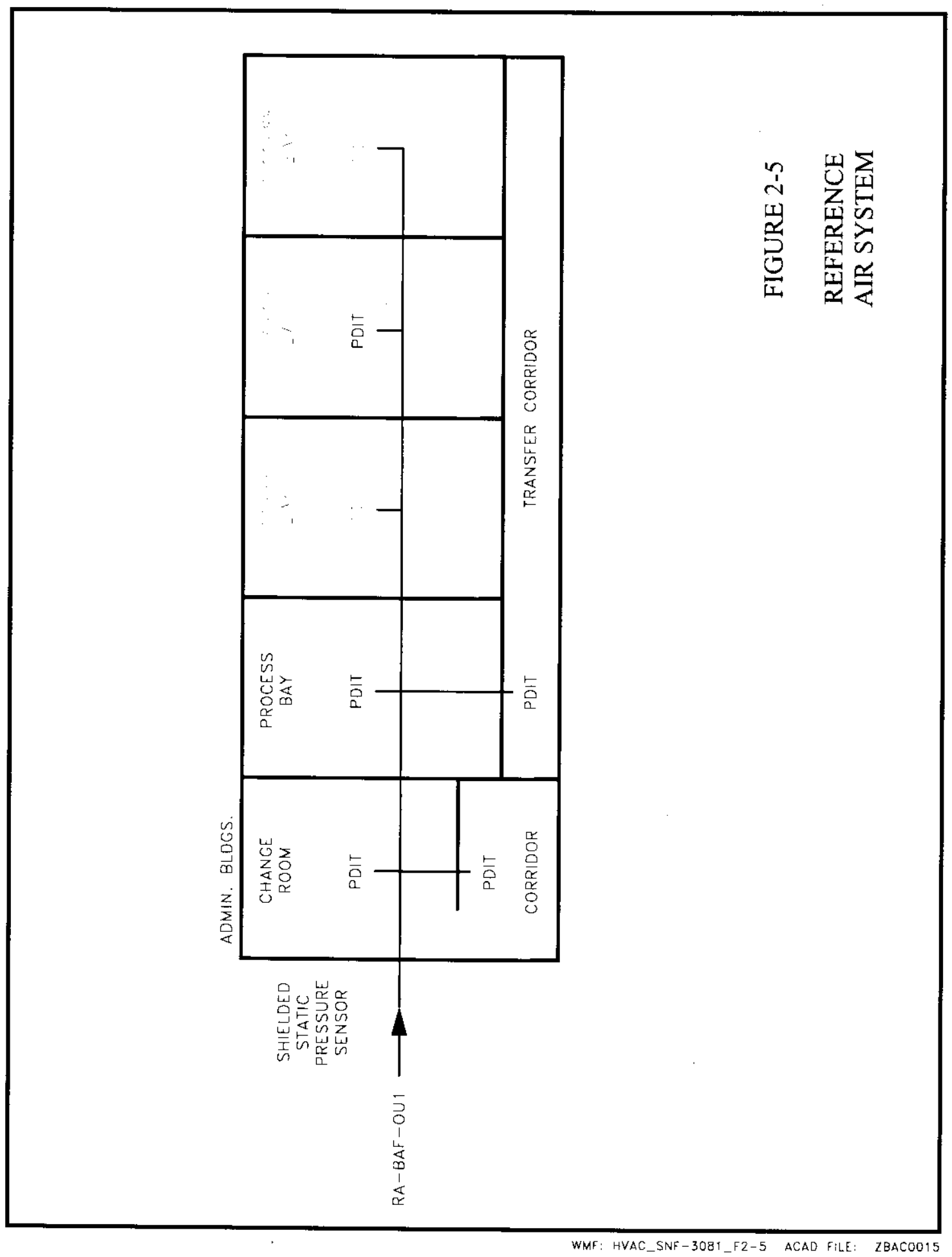




\subsubsection{Administration Building HVAC System}

The administration building HVAC system supplies a combination of recirculated and outside air to the CVDF administration building. The supply air is cooled or heated as required to maintain the administration building between $72^{\circ} \mathrm{F}$ and $75^{\circ} \mathrm{F}$. The system supplies in excess of six air changes per hour and maintains the administration building at a positive pressure with respect to the CVDF transfer corridor.

\subsubsection{Process Bay Recirculation HVAC System}

The process bay recirculation HVAC system supplies each process bay with fresh air while also recirculating the bay's resident air. The fresh air, drawn from outside the facility, provides makeup air to maintain air quality in the bay at six air changes per hour. The recirculation of process bay air serves to conserve energy. The fresh and recirculated air streams are mixed, filtered through a HEPA filter train, conditioned by either cooling or heating, and drawn into the supply fan, which discharges the air stream back into the process bay.

\subsubsection{Process Bay Local Exhaust HVAC and Process Vent System}

The process bay local exhaust HVAC and process vent system provides exhaust capability to remove contaminated and flammable gases from each process bay. Confinement dampers are provided in hood ducts to prevent cross-contamination between the various areas when the system is not operating. All of the exhaust is drawn through a bank of filters.

\subsubsection{Process General Supply/Exhaust HVAC System}

The process general supply/exhaust HVAC system supplies 100 percent outside air to the CVDF transfer corridor and PWC tank room. The supply air is filtered and cooled or heated as required to provide tempered air to the zones served.

The process general supply HVAC system consists of the outside air intake louver with isolation damper, the general supply air-handling unit (HVAC-AHU-8002), and the terminal electric heating coils.

The process general exhaust HVAC system provides exhaust capability to remove contamination from each process bay. Confinement dampers are provided at the wall ducts to prevent crosscontamination between the various areas when the system is not operating. All of the exhaust is drawn through a bank of filters

\subsubsection{Reference Air System}

The reference air system provides atmospheric air to 13 differential pressure transmitters/ indicators located throughout the CVDF. The air is provided as a reliable reference to atmospheric pressure for each applicable room. 


\subsection{REQUIREMENTS AND BASES}

\subsection{General Requirements}

Operational and functional requirements are taken from HNF-SD-SNF-DRD-002, Cold Vacuum Drying Facility Design Requirements, Section 6.0 "Facility Design Requirements."

\subsubsection{System Functional Requirements}

The following describes the performance requirements, basis for the requirements, and how the requirement is met in the CVDF HVAC systems. The requirements, identified in italics, are drawn from HNF-SD-SNF-DRD-002, Cold Vacuum Drying Facility Design Requirements.

\subsubsection{Design Requirements}

\subsection{Administration Building HVAC System}

1. Requirement: The administration area is conditioned with air from a dedicated air handling unit for this area.

Basis: A separate, dedicated air handling unit for the administration area reduces the possibility of a contamination spread to the administration area through operation at a positive pressure to preclude inleakage from adjacent areas or the outside. The operation and monitoring of the CVDF systems from a control room remote to the processing area within an independent air handling zone provides a safety factor assuring safe operational shutdown and monitoring in the event of a process upset or mishap.

How the system meet the requirement: Conditioned air is supplied to the CVDF administration building using dedicated heat pump HVAC-HTP-8001 located on the west side of the administration building (Drawing H-1-82199). Exhaust fan HVAC-EXHF8006 is associated with the heat pump.

2. Requirement: Air is recirculated with make-up air to maintain indoor air quality per ASHRAE 62 and provide air for the change room and shower area exhaust system. Air from these areas is exhausted directly to the outside and not recirculated.

Basis: Air is to be recirculated, to the maximum extent possible, to conserve energy while maintaining air quality standards. Air exhausted from the change/restrooms is not to be recirculated to the facility due to increased humidity and odor.

How the system meets the requirement: Heat pump HVAC-HTP-8001 supplies 3,140 $\mathrm{ft}^{3} /$ min of conditioned air to the building. This consists of $2,110 \mathrm{ft}^{3} /$ min recirculated air and $1,030 \mathrm{ft}^{3} / \mathrm{min}$ of outside air. This airflow volume is sufficient to provide in excess of six air changes per hour [Merrick HVAC calculations (Merrick 1996)]. Additionally, 0.5 $\mathrm{ft}^{3} /$ min of air per $\mathrm{ft}^{2}$ of floor space is provided to each of the changerooms. Air from the 
restrooms and changerooms is collected and exhausted at $800 \mathrm{ft}^{3} / \mathrm{min}$ using roof exhaust fan HVAC-EXHF-8005, which is provided with a birdscreen and backdraft damper. Each room is equipped with a separate exhaust register measuring $10 \mathrm{in.} \mathrm{by} 10 \mathrm{in}$. (Drawing H-1-82210).

3. Requirement: Differential pressure monitoring and alarms for upset conditions are provided between the administration and process areas to ensure the correct direction of airflow.

Basis: Each of the 13 differential pressure transmitters/indicators, including the process transfer corridor and Administration Building hall corridor, have separate alarms circuits provided in the control room. Differential pressure in the process transfer corridor is read at PDI 8073 and maintained between -0.05 in. w.g. (high alarm set point) and -0.15 in. w.g. (low alarm set point). Differential pressure in the Administration Building hall corridor is read on PDI 8079 and maintained above +0.01 in. w.g. (low alarm set point). During normal operation, all HVAC systems are operating and confinement is maintained with differential pressure control and correct air flows (area of lowest contamination potential to area of higher potential). During upset conditions, differential pressure cannot be maintained, confinement may be lost, affected differential pressure alarms are given in the control room, but the Administration Building HVAC is not curtailed. The HVAC system remains operational providing positive pressure within the Administration Building and assuring air flow into the process area.

How the system meets the requirement: Pressure differential transmitters/indicators are provided in the process area transfer corridor and in the administration building corridor. These transmitters/indicators monitor air pressure, relative to atmosphere, to ensure that each room's specific design pressure is maintained within design bounds. If the room/area differential pressure exceeds \pm 0.05 in. w.g. from the specific room design pressure high or low setting, a high or low differential pressure light will light and an alarm will annunciate at the control room panel. The administration area is maintained above +0.01 in. w.g., and the transfer corridor is maintained between -0.05 and -0.15 in . w.g. (see Drawing H-1-82207).

\subsection{Process Bay Recirculation HVAC System}

1. Requirement: Pursuant to DOE Order 6430.1A, wherever feasible, air is filtered and recirculated for energy conservation. Otherwise, 100 percent filtered and conditioned outside air is used for space ventilation.

Basis: Air is to be recirculated, to the maximum extent possible, to conserve energy while maintaining air quality standards. The process bay recirculation HVAC system recirculates the majority of the process bay air while drawing outside air to meet air quality requirements and provide make-up air for air removed from the process bay by the process bay local exhaust HVAC and process vent system. 
How the system meets the requirement: The process bay recirculation HVAC system recirculates the majority $\left(4,100 \mathrm{ft}^{3} / \mathrm{min}\right)$ of the process bay air while drawing outside air to meet air quality requirements and provide make-up air for air removed $\left(1,300 \mathrm{ft}^{3} / \mathrm{min}\right)$ from the process bay by the local exhaust HVAC system.

2. Requirement: The minimum deliverable air quantity at six air changes per hour, pending further hazard analysis, for all ventilation and exhaust air systems serving the confinement areas is provided.

Basis: The process bay recirculation HVAC system is sized to supply air to the process bays at a minimum rate of six air changes per hour.

How the system meets the requirement: This requirement is met by the process bay recirculation HVAC system based on the following calculations:

- $\quad$ Process bay volume $=1,800 \mathrm{ft}^{2}$ floor $\times 30 \mathrm{ft}$ height $=54,000 \mathrm{ft}^{3}$

- Process bay recirculation HVAC system minimum air flow $=5,400 \mathrm{ft}^{3} / \mathrm{min}$.

- Air changes per hour $=\left(5,400 \mathrm{ft}^{3} / \mathrm{min} / 54,000 \mathrm{ft}^{3}\right) \times(60 \mathrm{~min} / 1 \mathrm{~h})=6.0 / \mathrm{h}$

3. Requirement: Each process bay is served by a supply air system that recirculates a majority of the bay air to conserve energy.

Basis: Air is to be recirculated, to the maximum extent possible, to conserve energy while maintaining air quality standards. The process bay recirculation HVAC system recirculates the majority of the process bay air while drawing outside air to meet air quality requirements and provide make-up air for air removed from the process bay by the process bay local exhaust HVAC and process vent system.

How the system meets the requirement: The process bay recirculation HVAC system design specifies that $1,300 \mathrm{ft}^{3}$ of outside air is combined with $4,100 \mathrm{ft}^{3}$ of recirculated air per minute of operation. The recirculated air contributes 76 percent of the system output to the process bay.

4. Requirement: Make-up air is supplied, as required, to maintain air quality in the bay at six air changes per hour.

Basis: The process bay recirculation HVAC system is sized to supply air to the process bays at a minimum rate of six air changes per hour.

How the system meets the requirement: This requirement is met by the process bay recirculation HVAC system based on the following calculations:

- $\quad$ Process bay volume $=1,800 \mathrm{ft}^{2}$ floor $\times 30 \mathrm{ft}$ height $=54,000 \mathrm{ft}^{3}$

- Process bay recirculation HVAC system minimum air flow $=5,400 \mathrm{ft}^{3} / \mathrm{min}$.

- Air changes per hour $=\left(5,400 \mathrm{ft}^{3} / \mathrm{min} / 54,000 \mathrm{ft}^{3}\right) \times(60 \mathrm{~min} / 1 \mathrm{~h})=6.0 / \mathrm{h}$ 


\subsection{Process Bay Local Exhaust HVAC and Process Vent System}

1. Requirement: Primary confinement of releases that may occur in the vicinity of the top of the $\mathrm{MCO}$ is accomplished with a hood that draws the air from the area around the top of the MCO into a duct leading to a primary exhaust system. The hood provides operator protection during connection and removal of the process connectors.

Basis: The area in the vicinity of the top of the $\mathrm{MCO}$ is a potential release point for airborne radioactive contamination, especially during connection and removal of the process connectors. In order to protect operations personnel, a process hood should be supplied in the vicinity of the top of the MCO to contain any airborne radioactive contamination and transport it to a HEPA filter bank through a primary exhaust system.

How the system meet the requirement: The hood, connected to the local exhaust system by means of a flexible duct, is designed to effectively capture airborne contamination at its source by achieving a capture velocity of $0.64 \mathrm{~m} / \mathrm{s}(125 \mathrm{ft} / \mathrm{min})$ at the control point. The control point is defined as the location most distant from the hood where contamination may be generated.

2. Requirement: Exhaust air from the facility process area passes through a minimum of two HEPA filter stages before exhausting through the stack.

Basis: The process bay local exhaust HVAC and process vent system has the potential to transport radioactive particulates. The use of two HEPA filter stages should be employed to ensure that in the case of a failure of the first stage of HEPA filtration, the second stage will carry the filtration load.

How the system meets the requirement: The exhaust air passes through two HEPA filters located in filter housing HVAC-F-8040 prior to release up the stack.

3. Requirement: An exhaust system is provided to serve all the process bay areas.

Basis: The process bay areas will need to be exhausted to remove potential airborne radioactive contamination and provide air exchange.

How the system meets the requirement: The local exhaust system provides exhaust capabilities to each process bay hood connection and process vent including the PWC tank room tank vents.

4. Requirement: The hood is designed with a minimum inlet face velocity of $0.64 \mathrm{~m} / \mathrm{sec}$ $(125 \mathrm{ft} / \mathrm{min})$ in accordance with the requirements of DOE Order 6430.1 A, Chapter 11, and ACG1H Industrial Ventilation Manual hood design. The hood draws air away from the operator breathing space. The hood is mocked up and smoke-tested to verify its capture capability before fabrication and installation in the facility.

Basis: A process hood will be required to draw potentially contaminated air away from 
the operator breathing space. In order to ensure that the process hood is capable of performing this function adequately, it needs to be designed in accordance with industry accepted requirements and guidance.

How the requirement is met: The hood design meets the U.S. Department of Energy (DOE) and American Conference of Governmental Industrial Hygienists requirements based on Merrick HVAC calculations (Merrick 1996). The hood opening is located opposite the MCO from where operators are located during process activities. Smoketesting is performed to verify the hood's capture capability before fabrication and installation in the facility.

5. Requirement: The local exhaust system is a standalone system with 100 percent exhausted air.

Basis: The process bay local exhaust HVAC and process vent system is likely to contain airborne radioactive particulate contamination and is expected to be the airstream with the highest contamination level in the CVDF. Based on this, the system should not recirculate any portion of its air to the CVDF airspace.

How the system meets the requirement: The local exhaust system does not recirculate any portion of its air. All air entering the system is routed through two HEPA filter stages located in filter housing HVAC-F-8040 before being exhausted through the stack.

6. Requirement: The local exhaust system serves all the MCO process hoods and the process system exhaust and vent streams that may normally be contaminated, such as the vacuum pump exhaust, VPS condenser tank vents, and PWC and TW system tank vents.

Basis: The local exhaust system process hood is located on top of the MCO during normal operations. The process system exhaust and vent streams that may normally be contaminated are also located at the top of the $\mathrm{MCO}$ as well. The proximity of the system exhaust and vent streams to the process hood facilitates the use of the hood as the collection point for these contaminated air streams. The process bay local exhaust HVAC and process vent system serves the process hood for each active process bay.

How the system meets the requirement: The process system exhaust and vent streams that may normally be contaminated, such as the vacuum pump exhaust, VPS condenser tank vents, and PWC and TW system tank vents, are vented to the local exhaust system.

7. Requirement: The process bay local exhaust HVAC system branches in each bay provide an isolation damper near the process hood to preclude inadvertent backflow of radioactive material in the event of loss of ventilation flow conditions. This precludes backflow from SCHe system operation if local exhaust is not operating.

Basis: The process bay local exhaust HVAC system has the potential to transport radioactive particulates. In the event of an exhaust system shutdown, the potentially contaminated air in the exhaust system should be confined through the use of 
confinement isolation dampers.

How the system meets the requirement: An isolation damper is provided for each process bay (HVAC-DMP-8203, HVAC-DMP-8303, HVAC-DMP-8403, and HVACDMP-8503).

8. Requirement: Process bay local exhaust HVAC system design prevents an external hydrogen explosion in the local exhaust ductwork during cask venting by providing adequate dilution such that the combined streams have a hydrogen concentration less than the lower flammability limit.

Basis: Dilution air to keep the concentration of flammable gases below the lower flammability limit is required to prevent explosions.

How the system meet the requirement: The HVAC control system provides indication of system functions to the control panel. Flow switches FS-8*07 provide indication that minimum flow rates are available in the local exhaust ducts of each bay. The flow switches are installed in the local exhaust duct prior to HVAC-DMP- $8^{*} 03$ in each bay. The flow control system alarms at flow rates less then $1,000 \mathrm{cfm}$.

9. Requirement: Local exhaust system operation is designed to maintain or re-establish flow to prevent accumulation of hydrogen.

Basis: Continuous operation of the exhaust system during operation is essential to maintain adequate dilution air. In the event of a loss of power it will be necessary to restart the process bay local exhaust system to ensure adequate dilution air is maintained within the system.

How the system meet the requirement: The system is connected to the standby power system through a restart circuit to allow for the re-establishment of flow after a loss of power incident.

10. Requirement: The vent path is isolated from the cask vent and MCO vent tools at a loss of power. The capability to resume cask and MCO vent operations after a loss of power is provided.

Basis: Isolation of the vent path at loss of power is necessary to prevent backflow or cross contamination of systems.

How the system meet the requirement: The process bay local exhaust HVAC and process vent system is connected to the standby power system to allow restart of the system after a loss of power. The vent path is isolated by HVAC-DMP- $8 * 03$. 


\subsection{Process General Supply/Exhaust HVAC System}

1. Requirement: Deliverable air quantities are provided to all areas sufficient to remove heat, hazardous and radioactive particulate matter and gases, and other contaminants.

Basis: Removal of heat and hazardous, radioactive, and other contaminants is necessary to maintain a safe work place and prevent contamination.

How the system meets the requirement: The general supply air handling unit supplies $8,850 \mathrm{ft}^{3} / \mathrm{min}$ of 100 percent outside air to the process areas of the facility. The supply air quantities in each room provide a minimum of six air changes per hour, which is adequate to remove heat. Merrick HVAC calculations (Merrick 1996) developed the design flow quantities. The heating and cooling loads are examined and adequate air quantities re-supplied to meet those needs.

2. Requirement: The ventilation system meets all minimum deliverable air quantity requirements of ASHRAE Standard 62 and any other specific equipment requirements discussed in DOE Order 6430.1A, Sections 1550-2.5 and 1550-99.0.

Basis: ASHRAE and DOE 6430.1A establish minimum deliverable air quantities for workplace environments.

How the system meets the requirement: The system is required to provide 100 percent outside air at a minimum of six air changes per hour. The process general supply/exhaust HVAC system supplies 100 percent outside air through the air handling unit (HVACAHU-8002) and in-leakage.

3. Requirement: Exhaust air from the facility process area passes through a minimum of two HEPA filter stages before exhausting through the stack.

Basis: The use of two HEPA filter stages should be employed to ensure that in the case of a failure of the first stage of HEPA filtration, the second stage will carry the filtration load.

How the system meets the requirement: Air from the process general exhaust HVAC system is processed through two banks of HEPA filters in filter bank HVAC-F-8020 prior to discharge from the system.

4. Requirement: Facility air balance is achieved through manually set dampers and variable frequency fans.

Basis: In order to maintain an acceptable air balance within the CVDF, variable frequency fans and manually set dampers should be used. 
How the system meets the requirement: Manual dampers (HVAC-DMP-001, HVACDMP-003) and variable frequency fans (HVAC-EXHF-8025, HVAC-EXHF-8027) are incorporated into the system design.

5. Requirement: Exhaust fans use variable frequency-controlled motors that receive control signals from exhaust flow and/or pressure measurements.

Basis: In order to maintain an acceptable air balance within the CVDF, the exhaust fans should use variable frequency controlled motors that are controlled from the CVDF MCS.

How the system meets the requirement: Exhaust fans HVAC-EXHF-8025 and 8027 are controlled by variable frequency drives VFD-8025 and 8027 that receive input from filter differential pressures PDIS 8021, 8022, and 8023.

6. Requirement: Exhaust fan selection is based on the air change rates and pressure head calculated for the serviced areas or process cells.

Basis: Selection of exhaust fans for the system should be based on calculations that accommodate required air change rates and pressure heads for the serviced areas and process cells.

How the system meets the requirement: Merrick HVAC calculations (Merrick 1996) indicate that air change rates and pressure head were considered in sizing and selecting exhaust fans.

7. Requirement: Fan selection considers all anticipated normal operation, upset, offnormal, and faulted conditions of the facility.

Basis: Because the mode of operation of the facility is anticipated to be variable, the fan selection should be based to accommodate any of these modes.

How the system meets the requirement: The purchase specification calls for two fans. Each fan has been sized per Merrick HVAC calculations (Merrick 1996) to be able to supply 100 percent of the needed airflow for all anticipated normal operation, upset, offnormal, and faulted conditions of the facility without the aid of the other. 


\subsection{Reference Air System}

1. Requirement: $\mathrm{CHW} /$ cooling water, compressed/instrument air, helium, reference air, and stack sampling systems are provided to service the CVDF.

Basis: The reference air system is required to provide continuous monitoring of the air pressure within the designated areas/rooms of the CVDF. The system is an indication that the HVAC confinement systems are operating properly, which has a direct bearing on maintaining the facility in a safe operating condition. As a reliable reference, static atmospheric air is supplied to each pressure differential sensing instrument through noncorrosive piping from a shielded location providing a reliable atmospheric pressure reading independent of environmental conditions. Out of tolerance differential pressure conditions are provided by individual alarms in the control room.

The reference air system also includes temperature transmitters in selected locations constituting part of the temperature control loop. The temperature transmitter provides room reference temperature to the temperature controller, which adjusts flow of chilled water to cool the room/area or sends a signal to electrical heating coils to heat the room/area.

How the system meets the requirement: The reference air system provides continuous monitoring of the static pressure, relative to atmosphere, at 13 locations throughout the CVDF. Static atmospheric air is supplied, as referenced, to each pressure differential indicating transmitter (see Drawing H-1-82207).

2. Requirement: A reference air system is used to allow reliable atmospheric pressure reference to control the differential pressure in the process bays.

Basis: Differential pressure transmitters/indicators are located in each of the four operational process bays to maintain specific bay design pressure during operation. The reference air system provides atmospheric air to each bay transmitter/indicator through copper tubing connected to an atmospheric static pressure sensor. The static pressure sensor is shielded and located in a location to preclude upsets to the static pressure reference during adverse environmental conditions. If the differential pressure is \pm 0.05 in. w.g. of the process bay design pressure, a high-level or low-level alarm will annunciate in the control room.

How the system meets the requirement: A shielded outside static pressure sensor provides reliable atmospheric pressure via damper RA-001-CT (see Drawing H-1-82207) to each process bay through one-inch and two-inch copper tubing. Each process bay may be isolated from the reference air system by an inline hand valve (RA-V-201, 301, 401, or 501) as shown in Drawing H-1-82207. Differential pressure transmitters/indicators are located in each of the four process bays to maintain process bay design differential pressure. The pipe header and all differential pressure sensors lines are constructed of non-corrosive materials. 
3. Requirement: Reference air is provided for the differential pressure and zone controls for a reliable reference to atmospheric pressure. The reference air point is located in a well designed shielded damper such that rapid changes in wind speed or direction or sudden atmospheric changes do not affect the reference air system. The reference air piping is designed and constructed in accordance with ASME B31.9

Basis: The reference air system provides a reference standard of atmospheric air pressure from a shielded, atmospheric, static pressure sensor remote to the process area located on the Administration Building roof above the women's change room. The static atmosphere sensor is located in a shielded enclosure precluding plugging or adverse effects from environmental changes. The pipe header and all differential pressure sensor lines are constructed of noncorrosive copper tubing

How the system meets the requirement: The reference air system provides a reference standard of atmospheric air pressure from a shielded, atmospheric, static pressure sensor remote to the process area above the women's changeroom. The piping and instrumentation that make up the reference air system are designed to meet the criteria of performance category 2 construction and ANSI/ASME B31.3.

\subsubsection{Safety Analysis Report Functional Requirements}

The following requirements are included in the CVDF FSAR, Chapter 4 referenced section.

\subsection{Administration Building HVAC System}

1. Requirement: The Administration Building HVAC System does not have safety functional requirements in the FSAR, Chapter B4.

\subsection{Process Bay Recirculation HVAC System}

1. Requirement: Supply isolation damper. Each inlet isolation damper located at the process bay west wall must fail closed upon loss of electrical power or loss of instrument air to support restart of the local exhaust system on standby power and establish differential pressure in the process bay.

Basis: HNF-3553, Annex B, Section B4.4.4.

How the system meet the requirement: Each supply inlet isolation damper fails closed upon loss of electricity or loss of instrument air. This supports restart of the local exhaust on standby power to establish differential pressure in the process bay because no HVAC control functions are provided by standby power, and the differential pressure calculations for standby power operation were performed with these dampers closed. The inlet isolation dampers are pneumatically operated nuclear-grade dampers. The nuclear-grade dampers are in accordance with ANSI/ASME N509, Class 1, Construction Class B, to accomplish a "bubbletight" rating. 


\subsection{Process Bay Local Exhaust HVAC and Process Vent System}

The following evaluation of the process bay local exhaust HVAC and process vent system demonstrates that the functional requirements for this system have been accomplished by the system design.

1. Requirement: Fan operation. The process bay local exhaust system must be operating and accomplish adequate dilution of hydrogen introduced during the cask venting and processing activities, to ensure that the hydrogen lower flammability limit is not reached.

Basis: HNF-3553, Annex B, Section B4.4.3.

How the system meet the requirement: The process bay local exhaust HVAC and process vent system has a high degree of reliability. Redundant safety-significant exhaust fans are provided for the process bay local exhaust system. Each fan has $100 \%$ capacity of the local exhaust system flow to accomplish confinement and dilution flow requirements. The process bay local exhaust HVAC and process vent system has a "hand-off-auto" station located at each exhaust fan. When the fan's hand-off-auto station is in the "auto" position, the automatic temperature control system monitors and controls the exhaust system. The "on" position is used for fan testing only, and the switch is placed in the "auto" position for normal operations. The exhaust fans each have a manual isolation damper that must be placed in the open position for proper operation of the system. Engineering calculations demonstrating the adequacy of the local exhaust fan capacities are compiled in SNF-3001. Backflow dampers downstream of the exhaust fans preclude backflow into the fan that is not operating. The local exhaust fans are provided standby power that will restart the system within 1 minute. Local exhaust system operation on standby power does not require control signals, as all functions operate directly from the standby power system and restart circuit. No accidents are identified in Chapter B3.0 that require performance category 3 seismic qualification of the exhaust fans for the process bay local exhaust HVAC and process vent system.

2. Requirement: Flow alarm. A flow switch in each process bay branch to the process hood shall be provided with a remote alarm to the control room. It must be demonstrated that the flow in any process bay is adequate, prior to initiating the cask venting operation, and during $\mathrm{MCO}$ processing in each process bay.

Basis: HNF-3553, Annex B, Section B4.4.3.

How the system meet the requirement: Adequate flow in any process bay during $\mathrm{MCO}$ processing and prior to initiating the cask venting operation is demonstrated using safetysignificant flow switches in each branch. The flow switches provide a low-flow alarm in the control room for each process bay duct branch to inform operators of system functionality. The low flow switches activate at $1,150 \mathrm{ft}^{3} / \mathrm{min}$ (above $1,120 \mathrm{ft}^{3} / \mathrm{min}$ to account for a $10 \%$ error band of the flow switches per SNF-4451). A minimum flow of $1,000 \mathrm{ft}^{3} / \mathrm{min}$ is required for dilution of process vent discharge. 
3. Requirement: HEPA filters. The process bay local exhaust system HEPA filter installation must accomplish a $99.9 \%$ filter efficiency as credited in the Chapter B3.0 accident analyses.

HEPA filter loading shall be administratively controlled to less than $9.4 \mathrm{~g}$ of spent fuel while in service. The HEPA filter enclosure shall have the capability to accurately take repeatable measurements for the monitored radiation dose from the prefilters and HEPA filters. Measurements may be performed with portable instruments. Physical access to minimally shielded surveillance locations must be provided.

Basis: HNF-3553, Annex B, Section B4.4.3.

How the system meet the requirement: A system filter decontamination factor of at least $1.0 \times 10^{-3}$ is accomplished by either of the two installed stages of HEPA filtration, prior to discharge to the CVDF stack, any time the process bay local exhaust system is operating. The air is filtered with an $85 \%$ ASHRAE prefilter and two stages of HEPA filters before discharging the exhaust air via the CVDF exhaust stack. The HEPA filters conform to ANSI/ASME N509, with three test sections located within the filter box to accomplish testing in accordance with ANSV/ASME N510. Differential pressure across each stage of HEPA filters is monitored and alarmed in the control room. Flow indication ahead of the HEPA filters controls the exhaust fan speed to compensate for filter loading by maintaining constant volume flow. Differential pressure instrumentation is provided to demonstrate HEPA filter loading and presence.

The HEPA filter loading is administratively controlled to less than $9.4 \mathrm{~g}$ of spent fuel while in service. The HEPA filter enclosure has the capability to accurately take repeatable measurements for the monitored radiation dose from the prefilters and HEPA filters. Measurements are performed with portable instruments within their calibration period. Physical access to minimally shielded surveillance locations is provided. This is accomplished by not exceeding a contact dose reading in the designated locations on the HEPA filter box of $70 \mathrm{mR} / \mathrm{h}$ (SNF-2770, Chapter 6.0).

4. Requirement: Ductwork. The process bay local exhaust system ductwork must route discharge air to the HEPA filters from any process bay conducting normal process operations. The process bay local exhaust system must provide a discharge path via the ductwork and HEPA filter for the SCHe pressure venting and the $30 \mathrm{lb} / \mathrm{in}^{2}$ vent path.

Basis: HNF-3553, Annex B, Section B4.4.3.

How the system meet the requirement: All ductwork for the process bay local exhaust system is fabricated of round stainless steel duct or pipe and is of welded flange construction. Assurance that a discharge path is available to the HEPA filters is accomplished by the performance category 2 qualification of the process bay local exhaust system ductwork. The performance category 2 local exhaust duct was designed in accordance with ERDA 76-21 schedule methodology. Performance category 2 qualification is sufficient for discharge of the SCHe and $30 \mathrm{lb} / \mathrm{in}^{2}$ vent path during 
performance category 3 events because pinching off these process vent lines in order to retain high pressures is not probable. Process bay confinement is not required after a seismic event.

5. Requirement: Hood isolation damper. Each isolation damper located near the process hood must fail closed upon loss of electrical power. The dampers shall have the ability to re-open while the general-service instrument air is not operating.

Basis: HNF-3553, Annex B, Section B4.4.3.

How the system meet the requirement: The hood isolation dampers are pneumatically operated, nuclear- grade dampers. The nuclear-grade dampers are in accordance with ANSI/ASME N509, Class 1, Construction Class B, to accomplish a "bubbletight" rating. Each process hood isolation damper fails closed upon loss of electrical power. The damper actuators are provided a safety-significant, compressed-air reservoir for operation on standby power. The isolation dampers are interlocked to close upon fire alarm signal in each process bay.

6. Requirement: Cask venting. A flow restriction orifice and a flow valve interlocked to a low-flow switch in the cask venting connection is incorporated into the ductwork to preclude flammable mixtures in the ductwork and vent lines.

Basis: HNF-3553, Annex B, Section B4.4.3.

How the system meet the requirement: Dilution of hydrogen introduced during the cask venting activity to ensure that the hydrogen lower flammability limit is not reached is accomplished by the system normal operating capacity of $1,300 \mathrm{ft}^{3} / \mathrm{min}$, in conjunction with the cask venting orifice. A minimum flow of $1,000 \mathrm{ft}^{3} / \mathrm{min}$ is required for dilution during cask venting. This is interlocked to the flow valve in the cask vent line to interrupt venting on loss of flow. The flow rate requirement and orifice diameter are documented in SNF-4301.

7. Requirement: Standby operation. The process bay local exhaust HVAC and process vent system in the restart mode must be capable of maintaining differential pressure within the process bays under all design basis HEPA filter loading conditions without instrumentation or controls. It must also meet the minimum flow requirement of $1,000 \mathrm{ft}^{3} / \mathrm{min}$ for dilution.

Basis: HNF-3553, Annex B, Section B4.4.3.

How the system meet the requirement: The process bay local exhaust HVAC and process vent system in the restart mode with standby power is capable of maintaining differential pressure within the process bays under all design basis HEPA filter loading conditions without instrumentation or controls. The motor starter is energized by the standby power system and bypasses the variable speed drive for the fan, operating it at maximum capacity, which is adequate for all HEPA filter loadings. Each process hood 
isolation damper re-opens using the safety-significant, compressed-air source provided by the compressed-air reservoir in each process bay to restart on standby power. The control signal is provided by the standby power restart circuit. To accomplish sufficient differential pressure, the isolation dampers on the general exhaust system and the outside air inlet to the process bay recirculation HVAC system must fail closed. These dampers and their safety-significant function are addressed in their appropriate system sections. HVAC flow rate and differential pressure evaluations for the standby operation of the local exhaust system are documented in SNF-3001, Calculation MEI.2621.ME.6.

\subsection{Process General Supply/Exhaust HVAC System}

The following evaluation of the process general supply/exhaust HVAC system demonstrates that the functional requirements for this system have been accomplished by the system design.

1. Requirement: Ductwork. The process general exhaust system ductwork system must route discharge air to the HEPA filters from any process bay conducting normal process operations and from the process water tank room any time the PWC pumps are operating.

Basis: HNF-3553, Annex B, Section B.4.4.2.4.

How the system meet the requirement: Assurance that a filtered discharge path is available is accomplished by the performance category 2 qualification of the process general exhaust system. The performance category 2 general exhaust duct was designed in accordance with ERDA 76-21, Nuclear Air Cleaning Handbook, schedule methodology.

2. Requirement: HEPA Filters. The process general exhaust system HEPA filter installation must accomplish a 99.9\% filter efficiency, as credited in the Chapter B3.0 accident analyses, any time the process general exhaust system is operating.

Basis: HNF-3553, Annex B, Section B4.4.2.4.

How the system meet the requirement: A system filter decontamination factor of at least $1.0 \times 10^{-3}$ is accomplished by the two installed stages of testable, $99.97 \%$ efficient HEPA filtration prior to discharge to the CVDF stack. The filters are tested in accordance with ANSI/ASME N510 upon installation and annually thereafter.

3. Requirement: Differential Pressure. The general exhaust branch at each process bay, or process water tank room conducting process operations, must accomplish confinement of radioactive material for the process bays and the process water tank room by maintaining a negative building pressure and by flowing discharge air through HEPA filters.

Basis: HNF-3553, Annex B, Section B4.4.2.4.

How the system meet the requirement: Confinement of radioactive material in the process bays (bay $2,3,4$, and 5), and the process water tank room is assured by 
maintaining a negative building pressure in each area. This is demonstrated by the differential pressure instruments and alarms provided in the control room for each of these areas. Each process bay and the process water tank room is individually alarmed for differential pressure by the reference air system. The automatic temperature control system monitors HVAC functions and modulates the volume damper on the process bay recirculation $\mathrm{HVAC}$ system outside air inlet to maintain the designated differential pressure.

4. Requirement: Bay Isolation. The process general exhaust isolation dampers at each process bay must fail closed upon facility loss of electrical power or loss of instrument air to preclude back-flow and communication between process bays.

Basis: HNF-3553, Annex B, Section B4.4.2.4 .

How the system meet the requirement: The process general exhaust isolation dampers at each process bay fail-closed upon facility loss of electrical power or loss of instrument air, to preclude back-flow and communication between the process bays. The nuclear grade dampers are in accordance with ANSI/ASME N509, Class 1, Construction Class B, to accomplish a "bubbletight" rating.

\subsection{Reference Air System}

The reference air system provides DPITs, alarms, and the reference air header for safetysignificant low differential pressure alarms. Each of the system functional requirements is discussed below.

1. Requirement: Differential pressure instruments. DPITs for each process bay (bays 2, 3, 4 , and 5) and the process water tank room shall be provided with low differential pressure alarms in the control room.

Basis: HNF-3553, Annex B, Section B4.4.5.4 .

How the system meet the requirement: Safety-significant DPITs with low differential pressure alarm set points are provided in the process bays and the process water tank room. These DPITs are in addition and redundant to the DPITs provided for the general-service HVAC control via the automated temperature control system.

2. Requirement: Differential pressure alarms. The low differential pressure alarms must be able to remotely indicate to the control room a loss of negative building pressure relative to atmospheric pressure in the process bays $(2,3,4$, and 5), during $\mathrm{MCO}$ processing, and in the process water tank room, while the PWC recirculation pump is operating.

Basis: HNF-3553, Annex B, Section B4.4.5.4. 
How the system meet the requirement: Safety-significant differential pressure alarms are provided to the control room to allow timely response to ventilation upset conditions. Engineering calculations demonstrating the adequacy of the performance category 2 reference air low differential pressure alarm system design are listed in SNF-3001 .

3. Requirement: Reference air header. The reference air header and static pressure sensor must be available and functional to provide a reliable reference air signal whenever the DPITs and low differential pressure alarms are required to be functional.

Basis: HNF-3553, Annex B, Section B4.4.5.4.

How the system meet the requirement: The reference pressure is measured by a static pressure sensor located above the administration building roof. The reference air pipe header is fabricated of noncorrosive material (copper). Piping and instruments that make up the reference air system are supported in accordance with the requirements necessary to meet the criteria of performance category 2 construction. Engineering calculations demonstrating the structural adequacy of the performance category 2 reference air piping and installation design are listed in SNF-3001.

\subsubsection{Subsystem and Major Components}

There are no major subsystems associated with this system, while the major components are described throughout this document.

\subsubsection{Boundaries and Interfaces}

The HVAC system interfaces with the facility compressed air system, reference air, CHW, instrument air, fire protection systems, the standby power system, and the building structure. 
SNF-3081 Rev. 0

\subsubsection{Codes, Standards, and Regulations}

- $\quad 29$ CFR 1910, "Occupational Safety and Health Standards"

- Industrial Ventilation: Manual of Recommended Practice (ACGIH 1998)

- Handbook of Fundamentals (ASHRAE 1997)

- $\quad$ ANSI N13.1, Guide to Sampling Airborne Radioactive Materials in Nuclear Facilities

- $\quad$ ANSI N512, Protective Coatings (Paints) for the Nuclear Industry

- ANSI/ASHRAE-52.68, Method of Testing Air Cleaning Devices Used in General Ventilation for Removing Particulate Material

- ANSI/ASHRAE-62a, Ventilation for Acceptable Indoor Air Quality

- ANSI/ASME N509, Nuclear Power Plant Air Cleaning Units and Components

- ANSI/ASME AG-1, Code on Nuclear Air and Gas Treatment.

- $\quad$ ANSI/ASME N510, Testing of Nuclear Air Cleaning System

- $\quad$ ANSI/NFPA 45, Standard on Fire Protection for Laboratories Using Chemicals

- $\quad$ ANSI/NFPA 90A, Standard for the Installation of Air Conditioning and Ventilating Systems

- $\quad$ ANSI/NFPA 90B, Standard for the Installation of Warm Air Heating and Air Conditioning Systems

- $\quad$ ANSI/NFPA 91, Standard for Exhaust Systems for Air Conveying of Materials

- $\quad$ ANSI/NFPA 801, Standard for Facilities Handling Radioactive Materials

- $\quad$ DOE Order $5480.1 \mathrm{~A}$

- $\quad$ DOE Order 6430.1A, General Design Criteria, Sections: 0110-12.4, 1161-4, 1300-11.2, $1300-3.6,1300-7,1550,1550-2.5 .5,1550-2.5 .6,1550-99.0,1589-990.0 .1$, Chapter 11

- $\quad$ ERDA-76-21, Nuclear Air Cleaning Handbook

- GH-CLIM-01, Design Climate Data for the Hanford Site.

- $\quad$ Uniform Building Code (UBC 1994)

- WAC 246-247, "Radiation Protection-Air Emissions" 
SNF-3081 Rev. 0

- WAC 173-400, "General Regulations for Air Pollution Sources"

- WAC 173-460, "Controls for New Sources of Toxic Air Emissions"

\subsubsection{Operability}

3.1.5.1 Administration Building HVAC System. There are no TSR assumptions for the Administration Building HVAC System.

3.1.5.2 Process Bay Recirculation HVAC System. The following assumptions associated with the process bay recirculation HVAC system requires TSRs to ensure performance of the safety function.

- The supply inlet isolation damper and fail-closed actuator for any process bay is functional during any processing operation in any process bay.

3.1.5.3 Process Bay Local Exhaust HVAC and Process Vent System. The following assumptions associated with the process bay local exhaust system require TSRs to ensure performance of the safety function.

- $\quad$ The system minimum flow requirement is met while processing an MCO in that process bay.

- The proper cask venting orifice is properly installed in the system.

- The installed flow switch and remote low-flow alarm on the process bay branch of the ductwork is functional in each process bay during MCO processing in that bay.

- The flow switch interlock to cask venting valve is functional.

- The HEPA filter accomplishes the efficiency requirements and a minimum differential pressure of a 1-in. water column.

- The HEPA filter inventory is less than $9.4 \mathrm{~g}$ of spent fuel to protect the assumption in the Chapter B3.0 accident analysis. (This is accomplished by not exceeding a contact dose reading in the designated locations on the HEPA filter box of $70 \mathrm{mR} / \mathrm{h}[\mathrm{SNF}-2770$, Chapter 6.0].)

- $\quad$ The isolation damper fail-closed actuator for any process bay is functional during any processing operation in that process bay.

- The system restart capability with standby power is functional to reestablish minimum flow within 1 minute. 
SNF-3081 Rev. 0

3.1.5.4 Process General Supply/Exhaust HVAC System. The following assumptions associated with the process general exhaust system require TSRs to ensure performance of the safety function.

- The HEPA filters are tested in accordance with ANSI/ASME N510 upon installation and annually thereafter.

- The flow path of ductwork (design feature) is available and can be demonstrated by normal differential pressure readings.

- The isolation damper and fail-closed actuator for any process bay are functional during any processing operation in any process bay. The exhaust isolation dampers shall fail closed upon loss of electrical power and loss of air.

- A minimum differential pressure reading across HEPA filters of a 1-in. water column.

3.1.5.5 Reference Air System. The following assumptions associated with the reference air system require TSRs to ensure performance of the safety function.

- $\quad$ The system must be functional during processing activities in any process bay and whenever the process water pumps are operating.

- The DPITs and alarms must be able to detect a loss of negative building pressure relative to atmospheric pressure in the process bays (bays 2, 3, 4, and 5) and the process water tank room during processing activities in any of those areas.

- The process bay ventilation systems are maintaining normal differential pressures prior to initiating MCO processing in a bay.

- The process water tank room ventilation system is maintaining normal differential pressure prior to initiating MCO draining operations and at all times that any PWC pumps are operating.

\subsection{Special Requirements}

\subsubsection{Radiation and Other Hazards}

1. Requirement: To prevent possible contamination, air in the rooms connecting the administration area to the process area is not exhausted to the outside, but directed towards the process area and the HEPA-filtered exhaust system.

Basis: Personnel protection contamination control measures are to be in place that preclude contamination backflow from the CVDF process areas to adjacent areas in the Administration Building. Therefore, air in the Administration Building areas adjacent to the process areas is not to be exhausted through the Administration Building HVAC system. 
How the system meets the requirement: The administration area of the CVDF has an independent supply and exhaust system that operates at a positive pressure to preclude inleakage from adjacent areas or the outside.

2. Requirement: The administration area is designed to remain at a positive pressure relative to atmospheric pressure or $12.5 \mathrm{~Pa}$ (+0.05 in. w.g.) during normal and atmospheric upset conditions.

Basis: Providing positive pressure in the administration areas adjacent to the process area (which are under partial negative differential pressure), and directional air flow into the process areas from the administration areas, will provide air flow patterns that prevent possible contamination.

How the system meets the requirement: Drawing H-1-82207 indicates a low pressure alarm setpoint of 0.01 in. w.g. for the administration building air pressure at the hall corridor adjacent to the process area. This indicates that the building is maintained at greater than 0.01 in. w.g.

3. Requirement: The CVDF HVAC system is demonstrated not to cause adverse harm to facility personnel due to recirculation of CVDF exhaust stack air into the administration building.

Basis: The CVDF stack discharge air is HEPA-filtered to provide airborne radioactive material confinement. The stack will be located and designed to preclude CVDF stack discharge from entering the Administration Building HVAC system and causing adverse harm to personnel.

How the system meets the requirement: Merrick HVAC calculations (Merrick 1996) develop the minimum stack height required to ensure that CVDF exhaust stack air is not recirculated into the administration building HVAC system. A minimum stack height of $44.4 \mathrm{ft}$ was calculated; a stack height of $48.0 \mathrm{ft}$ is used for the design of the CVDF.

4. Requirement: An air stream with the potential to introduce radioactive material into the CVDF is filtered prior to release into the environment.

Basis: Filtering of the air streams with the potential to contain radioactive material is necessary to prevent contamination of the environment. 


\section{How the system meets the requirement:}

- The process bay recirculation HVAC system incorporates two HEPA filter stages to contain airborne radioactive material and particulates. The process bay air is continuously recirculated, even during process upset conditions, to assure filtration of airborne radioactive particles. The process air not recirculated is evacuated through the MCO process hood to the local HVAC exhaust system, which filters the air through two stages of HEPA filters before its release to the environment.

- The process general supply/exhaust HVAC system manages the spread of contamination from accidental release through the use of negative pressures, differential pressures, and equipment interlocks; these systems provide secondary confinement in the event of an accidental release. Negative pressures with respect to the environment ensure that airflow is always into the CVDF, providing one means of confinement. Differential pressure causes airflow to move from areas of lesser potential contamination to areas of greater potential contamination, providing another means of confinement. Finally, the supply and exhaust fans are interlocked. Should the exhaust fan fail, the supply fan is tripped, preventing pressurization of the process areas, loss of confinement, and release of contamination.

5. Requirement: Ventilation flows and pressure differentials are detected and monitored throughout the facility as required to prevent the possible spread of hazards, such as radioactive contamination. All confinement ventilation airflows and pressure differentials are alarmed if out of compliance.

Basis: The CVDF monitors the differential pressures to assure ventilation flows are maintained within design specifications to provide containment of radioactive/hazardous materials. Each process bay is monitored for differential pressure. The differential pressure is set and maintained, relative to atmospheric, to design criteria to provide containment of possible hazards within the bay. If the differential pressure exceeds design tolerances, an alarm will annunciate in the control room. Differential pressure is also monitored across each stage of the HEPA filter bank. Differential pressure alarms will annunciate in the control room.

How the system meets the requirement: Each process bay is monitored for differential pressure, relative to atmosphere, through a pressure differential indicating transmitter, which is displayed on the pressure differential indicator (see Drawing H-1-82207). If the differential pressure exceeds the specific process bay design pressure ( \pm 0.05 in. w.g.), a low or high alarm will annunciate in the control room. Differential pressure is also monitored across each stage of the HEPA filter bank. Differential pressure across the filter of $3.0 \mathrm{in.}$ w.g. will annunciate a high differential pressure alarm in the control room. A high-high alarm will also annunciate in the control room at 4.0 in. w.g., signifying mandatory change-out of the filter. The CVDF monitors the differential pressures to 
ensure that ventilation flows are maintained within design specifications to provide containment of radioactive/hazardous materials.

6. Requirement: Filter plenums located inside process buildings are separated from all parts of the building and enclosed by two-hour, fire-rated construction.

Basis: This requirement is to provide containment of radioactive materials in case of fire.

How the system meets the requirement: The filter plenums located in the process bays are will not be contaminated during normal operations. The FHA addresses this issue.

7. Requirement: A non-seismic confinement isolation damper is provided on the air intake to prevent backflow of air to the outside in the event of system shutdown.

Basis: Backflow isolation dampers are provided on the outside air inlet to provide for confinement of radioactivity. Seismic qualification of dampers is not required because CVDF negative pressure is not required after the DBA.

\section{How the system meets the requirement:}

- This requirement is met by an isolation damper in each process bay (HVACDMP-8201, HVAC-DMP-8301, HVAC-DMP-8401, HVAC-DMP-8501) designed to fail in the closed position. A backdraft damper is also provided inline as a redundant component that prevents backflow of air to the outside in the event of a system shutdown.

- Non-seismic confinement isolation damper HVAC-DMP-8001 performs this function for the general supply system (see Drawing H-1-83769).

8. Requirement: Any recirculated air in the process area HVAC system passes through a minimum of two HEPA filter stages to control contamination.

Basis: Two stages of HEPA filtration are used to contain the contamination from the process building.

How the system meets the requirement: The process bay recirculation HVAC system incorporates two HEPA filter stages in its design.

9. Requirement: Ventilation flows and pressure differentials are detected and monitored throughout the facility as required to prevent the possible spread of hazards, such as radioactive contamination. All confinement ventilation airflows and pressure differentials are alarmed if out of compliance. 
Basis: The CVDF has the potential to contain airborne hazards in its airspace. In order to prevent the possible spread of airborne hazards, ventilation flows and pressure differentials should be detected and monitored throughout the facility. Alarms should be employed if the ventilation air flows and pressure differentials are out of compliance.

How the system meets the requirement: Air measuring stations, as noted in Section 5.3.4, are incorporated into the process general supply/exhaust HVAC system (H-183769). Pressure differentials are also monitored; setpoints for filter pressure differentials are provided in Section 5.5.4.

10. Requirement: Facility airflows travel from areas of less contamination potential to areas of greater contamination potential.

Basis: Facility air flows should be from areas of less contamination potential to areas of greater contamination potential to minimize the possibility that a low-contamination or non-contaminated area would become more contaminated.

How the system meets the requirement: The process general supply/exhaust HVAC system establishes differential negative pressures within the CVDF by mechanically exhausting more air than is supplied to the system. These differential negative pressures (noted on Drawing H-1-83769) ensure that facility airflow is from areas of lesser potential contamination to areas of greater potential contamination.

11. Requirement: Cross-contamination paths from one process bay area to another room or bay are prevented.

Basis: Cross-contamination paths within the process bay areas should be prevented to eliminate the possibility of transferring contaminated air from an area of higher contamination potential to an area of lower contamination potential.

How the system meets the requirement: Cross-contamination paths within the process area are minimized. Paths that do exist between the process bays, mechanical room, and transfer corridor rooms are equipped with backdraft dampers to prevent development of cross-contamination paths in the event of process area pressurization (H-1-83769).

12. Requirement: Exhaust ventilation systems are provided with HEPA filtration to minimize the release of hazardous materials through the exhaust path (DOE Order 6430.1A, Section 1550-2.5.5). All HEPA filtration design and construction practices conform to the guidelines of ERDA-76-21, Nuclear Air Cleaning Handbook, Chapter 4; and ASME N509.

Basis: In order to protect the environment and operating personnel, HEPA filtration should be employed to minimize the release of hazardous materials through the exhaust path. 
How the system meets the requirement: The process general supply/exhaust HVAC system provides an 85 percent efficient pre-filter and two stages of HEPA filtration prior to discharge through the exhaust stack.

13. Requirement: The CVDF is designed to maintain adequate confinement, defined as a condition that ensures that any accidental releases from the primary confinement occurring during a facility shutdown do not result in unacceptable dose consequences to onsite workers or offsite public.

Basis: This function will be required to prevent releases to the environment that would result in unacceptable dose consequences to onsite workers or offsite public.

How the system meets the requirement: Backflow and isolation dampers are provided at the air egress points for the process general supply/exhaust HVAC system. These function to prevent backflow in the event of facility shutdown.

14. Requirement: Each process bay (excluding the spare bay) and PWC tank room are served by an exhaust system with sufficient capacity and standby functions to ensure adequate controlled ventilation flow as required to contain contamination in the event of a credible breach (defined in the CVDF SAR) in the primary confinement barrier.

Basis: The operations in the process bays (excluding the spare bay) and PWC tank room have the potential for a credible breach in the primary confinement barrier. The process general supply/exhaust HVAC system should be designed to contain accidental releases from the primary and/or secondary confinements. This function will be required to prevent releases to the environment that would result in unacceptable dose consequences to onsite workers or offsite public.

How the system meets the requirement: The process general supply/exhaust HVAC system provides circulation to each of these areas at the desired air exchange rate. Redundant exhaust fans (HVAC-EXHF-8025, 8027) are provided to ensure continuous circulation in the event of exhaust fan failure.

15. Requirement: Air from the process area support rooms is exhausted into the HEPA filter exhaust system.

Basis: Air is exhausted into the HEPA filter exhaust system in conjunction with the requirement that all air exhausted be HEPA filtered to prevent the release of any contamination.

How the system meets the requirement: Drawing H-1-83769 shows the flow diagram for the CVDF HVAC systems. It can be seen that air exhausted from the process area support rooms is exhausted to the process general exhaust HVAC system and HEPAfiltered prior to discharge. 
16. Requirement: Confinement isolation dampers are provided on all duct branches connecting to the general exhaust system to prevent backflow in the event of exhaust system shutdown.

Basis: Confinement isolation dampers prevent backflow in the event of exhaust system shutdown. Prevention of backflow is required to maintain workspace environment.

How the system meets the requirement: Drawing H-1-83769 specifies that backdraft dampers are used to prevent backflow in the event of exhaust system shutdown. The drawing also shows that dampers are provided on each branch line connecting to the main exhaust duct (HVAC-DMP-8015, 8018, 8019, 8102, 8202, 8302, 8402, 8502, and 8017).

17. Requirement: All secondary confinement primary and secondary exhaust openings in the building are equipped with HEPA filters that block the contamination out of the process building during a shutdown period. This path is available for all potential accidents except fire.

Basis: HEPA filters block the spread of contamination out of the process building during any shutdown period to protect the environment and worker safety.

How the system meets the requirement: The process general exhaust HVAC system uses HEPA filters prior to air stream discharge. These HEPA filters remain in place regardless of system operability (see Drawing H-1-83769).

18. Requirement: The number of exhaust filtration stages is sufficient to limit concentrations of airborne radioactive particulate released to the environment to less than the applicable limits at the point of discharge during all anticipated operating and DBA conditions.

Basis: Airborne concentrations of radioactive particulate must be maintained at less than the applicable limits to achieve compliance with Federal and State regulations.

How the system meets the requirement: The exhaust system uses two stages of 99.97 percent efficient HEPA filtration to accomplish this.

\subsubsection{ALARA}

1. Requirement: Sufficient access to and working space around HVAC equipment are provided to permit ready and safe operation and maintenance of such equipment. Access and working space are in accordance with supplier and International Conference of Building Officials code requirements.

Basis: To provide for equipment operation and maintenance, worker safety, egress and ingress, and to maintain the policies of as low as reasonably achievable (ALARA), the process bay recirculation HVAC equipment is designed and located to provide adequate space to operate and maintain the process bay recirculation HVAC system equipment. 


\section{How the system meets the requirement:}

- The process bay recirculation HVAC equipment is located on the mezzanine in the process bay. Drawing H-1-82196 indicates that adequate space is available to operate and maintain the process bay recirculation HVAC equipment.

- $\quad$ The CVDF HVAC systems locate the HEPA filtration as close as possible to any expected airborne contamination sources. The filtration units and fans are located in the CVDF in a location designed to accommodate the equipment footprint and personnel egress and maintenance requirements.

- The general supply/exhaust HVAC equipment is located in the mechanical room and transfer corridor. Drawings H-1 82197, Cold Vacuum Drying Facility HVAC Plan Transfer Corridor, and H-1-82198, Cold Vacuum Drying Facility HVAC Plan Mechanical Room, indicate that adequate space is available to operate and maintain the process general supply/exhaust HVAC system equipment.

- The process general supply/exhaust HVAC system locates HEPA filters in the mechanical room on the second floor, directly adjacent to the return register from each of the process bays. Placement within the mechanical room accommodates equipment footprint and allows personnel egress for operations and maintenance (see Drawing H-1-82198).

2. Requirement: Air filtration housings are designed so that a tier of filters can be completely isolated from the ventilation system during filter element replacement, and are designed and located with appropriate radiation protection to maintain occupational doses as low as reasonably achievable (ALARA) during operations and maintenance.

Basis: The system should be designed for continuous operation during filter element replacement to minimize the affect to processing operations. The location of the filter housings should be in areas not normally occupied by operations personnel, and designed for quick maintenance to maintain occupational doses ALARA during operations and maintenance.

How the system meets the requirement: The purchase specification calls for a bagin/bag-out filter housing. This housing is designed so that a tier of filters can be completely isolated from the ventilation system during filter element replacement. The housing is located in the mechanical room, which does not normally serve to maintain occupational doses ALARA during normal operations. Filter maintenance involves a minimum of exposure time by design, which serves to maintain occupational doses ALARA during maintenance activities. 


\subsubsection{Nuclear Criticality Safety}

No criticality safety requirements are applicable to this system.

\subsubsection{Industrial Hazards}

There are no unique industrial hazards requirements associated with this system.

\subsubsection{Operating Environment and Natural Phenomena}

1. Requirement: Design conditions for the CVDF location are obtained from GH-CLIMOD, Design Climate Data for the Hanford Site. A summary of conditions at the CVDF site is as follows:

- $\quad$ Prevailing wind: NW

- $\quad$ Outdoor design temperatures: $9{ }^{\circ} \mathrm{F}$ winter; $97^{\circ} \mathrm{F} \mathrm{db}, 67^{\circ} \mathrm{F}$ wb summer

- Indoor design temperatures: $72^{\circ} \mathrm{F}$ winter, $75^{\circ} \mathrm{F}$ summer.

Basis: The system must be designed to withstand the operating environment in which it is located.

How the system meet the requirement: The air handling unit air handling unit heating coil is designed to accommodate entering air temperatures as low as $9^{\circ} \mathrm{F}$ (winter design temperature). The air handling unit cooling coil is designed to accommodate entering air temperatures as high as $97^{\circ} \mathrm{F} \mathrm{db}$ (summer design temperature). Additionally, the zone terminal heating coils are designed to provide conditioned air to the process areas between $75^{\circ} \mathrm{F}$ and $85^{\circ} \mathrm{F}$ (indoor design temperatures).

\subsubsection{Human Interface Requirements}

1. Requirement: Detection of radioactivity in the process bay room air initiates an alarm. In the event of a radiation alarm, the supply system continues to operate, recirculating air through the HEPA filters.

Basis: Detection of radioactivity in the process bay will sound an alarm in the process bay and will annunciate an alarm in the control room. The process bay radiation alarm is not interlocked with the process bay recirculation HVAC system. The process bay recirculation HVAC system will continue to operate, recirculating air through the HEPA filters, upon detection of radioactivity in the process bay. Operators in the control room will assure continued monitoring of the system operation.

How the system meets the requirement: The process bay radiation alarm is not interlocked with the process bay recirculation HVAC system. A radiation alarm sounds in the process bay and an alarm annunciates in the control room. Operator action is to maintain the HVAC system in an operational mode, i.e., supply fan running. 
2. Requirement: Provide a control system for the HVAC control system with interfaces (remote setpoints and remote indication as necessary) with the facility or process MCS capable of airflow control, fan speed adjustment, and pressure zone maintenance.

Basis: The CVDF requires that air flow control be employed to create an air flow from areas of lower contamination potential to areas of higher contamination potential

How the system meets the requirement: The HVAC systems, in the process areas, are controlled by a Automatic Temperature Control system that automatically runs the system to maintain design operating limits in the CVDF.

The process general supply/exhaust HVAC system provides airflow measuring stations (HVAC-AMS-8007, 8024), variable frequency drives (VFD-8025, 8027), and differential pressure monitors (PDIS 8001, 8002, 8021, 8022, 8023). These sensors interface with the MCS to provide airflow control within the CVDF.

\subsubsection{Specific Commitments}

1. Requirement: For the process bay local exhaust and PWC tank room exhaust up to the first HEPA filter, round ductwork or pipe is used for confinement of exhaust system ventilation unless its installation is impractical. Exhaust ducts are sized for the transport velocities needed to convey all particulate without settling.

Basis: The process general supply/exhaust HVAC system has the potential to transport radioactive particulates. Round duct work or pipe should be employed to transport this potentially contaminated airstream in order to minimize particulates congregating in corners within the ductwork. Exhaust ductwork should be sized so that the airstream velocity is high enough to transport all particulates without settling.

How the system meets the requirement: Drawing H-1-82198 indicates that the design specifies round duct work up to the first HEPA filter in-housing HVAC-F-8020.

2. Requirement: Protective coatings are applied to the interior of exhaust duct work serving the confinement areas if other than stainless steel ductwork is used. These coatings meet the requirements of ANSI N512 for light exposure.

Basis: The process general supply/exhaust HVAC system has the potential to transport radioactive particulates. Protective coatings shall be applied if necessary to minimize the potential for radioactive particulate adherence to the duct walls.

How the system meets the requirement: The exhaust ductwork is fabricated from galvanized steel. The galvanized coating of the ductwork meets the requirement of ANSI N512 for light exposure. 
3. Requirement: Dampers comply with the requirements determined in Table 5.12 of ERDA-76-21. Duct systems serving the confinement areas of the facility are not acoustically treated.

Basis: The process general supply/exhaust HVAC system has the potential to transport radioactive particulates. Because of its potential to contain radioactive particulates, dampers in the system should comply with the requirements outlined in ERDA-76-21. Acoustically treated duct systems would entrap particulates prior to their being filtered from the airstream by the HEPA filters.

How the system meets the requirement: The construction specification (15890) requires fabrication and installation in accordance with NFPA 90A, SMACNA 1208, and SMACNA 1481. Design of the HVAC system and dampers is included in the Merrick HVAC calculations (Merrick 1996).

\subsection{Engineering Disciplinary Requirements}

\subsubsection{Civil and Structural}

The civil design requirements in HNF-SD-SNF-DRD-002 were reviewed and evaluated for applicability to the CVDF HVAC systems. No pertinent requirements were identified. The structural requirements were also reviewed and the following applicable design requirements identified, and implemented.

3.3.1.1. All equipment is assigned either to seismic performance category 0 and 1 for general services, performance category 2 for safety-significant functions, or performance category 3 for safety-class functions in accordance with the seismic design requirements in the design requirements document (DRD).

All equipment within the CVDF with the potential, because of seismic-induced failure, of preventing safety-class systems, structures, and components (SSCs) from performing safety-class functions are anchored for the design basis seismic performance category 3 criteria in accordance with WHC-SD-GN-DGS-30006, Seismic Design Guide for Safety Class 3 and 4 Equipment at the Hanford Site. Seismic design requirements for all SSCs are assigned and documented in the Safely Equipment List (HNF-SD-SNF-SEL-002 1998).

\subsubsection{Mechanical and Materials}

1. Requirement: Industrial ventilation design air quantities and transport velocities are calculated according to the calculation methods prescribed by the requirements in the ACGIH Industrial Ventilation Manual, ASHRAE Fundamentals, UBC, 29 CFR 1910, NFPA 45, NFPA 90A, NFPA 91, and NFPA 801. Design heating and cooling load calculations are developed and presented as part of the design packages.

Basis: This is a fundamental design requirement driven by the usage of national codes and standards for the design of the system. 
How the system meet the requirement: Merrick HVAC calculations (Merrick 1996) were performed to the specified calculated methods. The Merrick HVAC calculations (Merrick 1996) provide the design heating and cooling load calculations

2. Requirement: HEPA filters and housings are of a fluid-seal, bag-in/bag-out type. The filter housings are fabricated from 304-L stainless steel with a 2-B mill finish. All filter housing joints and seams are welded and airtight when tested in accordance with ASME N510 at 1.25 times the rated fan capacity per ASME N509, or with ERDA-76-21, Table 5 , whichever is more stringent. They are equipped with local differential pressure readouts and alarm high interfaces with the MCS to monitor the loading of the filters.

Basis: This is a requirement to achieve compliance with the ASME codes chosen for this project.

How the system meet the requirement: HVAC system air filtration housings specify the use of a bag-in/bag-out style filter that has provisions for routine, in-place testing of HEPA filter systems. The construction specification (15856) for the CVDF HVAC systems requires that type 304-L stainless steel with a 2-B mill finish be issued for filter housing fabrication. The specification also states that filter housings are to be 100 percent scam-welded, airtight, with no burrs or sharp edges. The joints must be capable of withstanding 10 in. w.g., positive or negative. Each HEPA filter has differential pressure-indicating gauges monitoring the pressure drop through each HEPA filter stage. The HEPA filters have a switch (PDIS) that initiates an alarm when the differential pressure across the filter reaches its high alarm setpoint and again when it reaches its high-high alarm setpoint. The alarms are transmitted, via the ATC, to the control room where they are annunciated on the enunciator panel.

3. Requirement: Ducting systems are designed to minimize pressure drops through the system while maintaining the required entrainment velocities.

Basis: This is standard design practice to achieve maximum system efficiency.

How the system meets the requirement: Merrick HVAC calculations (Merrick 1996) were performed to size the HVAC system components, equipment, and systems to specified HVAC design requirements. The duct sizing, pressure drops, airflows, and air velocities are contained in the Merrick HVAC calculations.

4. Requirement: The exhaust air treatment systems contains a HEPA filter train with a minimum of two HEPA filter stages or equivalent efficiency filtration, as required, pending a safety analysis of offsite accidental exposure criteria. Each HEPA filter stage is testable to ANSI/ASME N510 criteria.

Basis: The process bay local exhaust HVAC and process vent system provides confinement of radioactive material within the process bay during processing operations if a release from primary confinement occurs. Based on this function, two HEPA filter 
stages should be employed to entrap particulate radioactive material before the airstream is released to the environment

How the system meets the requirement: The exhaust air treatment systems include a HEPA filter train of two HEPA filter stages, located in filter housings HVAC-F-8040 and HVAC-F-8020. Filter housings HVAC-F-8040 and HVAC-F-8020 provide test ports upstream and downstream of each individual HEPA filter stage.

5. Requirement: Deliverable air quantities are provided to all areas sufficient to remove heat, hazardous, and radioactive particulate matter and gases, and other contaminants.

Basis: Processing activities in the CVDF will produce heat and may produce hazardous and radioactive particulate matter and gases, and other contaminants. The deliverable air quantities required to keep the CVDF airspace clean and comfortable for personnel should be calculated and incorporated into the design of the process general supply/exhaust HVAC system. Temperature and air quality maintenance ensures personnel comfort and safety as well as protect equipment from temperature extremes that may cause it damage otherwise.

How the system meets the requirement: The HVAC systems are designed to deliver air quantities sufficient to remove radioactive particulates, radioactive gases, and heat generated from processing operations and occupation of the building (Merrick 1996).

6. Requirement: The ventilation system meets all minimum deliverable air quality requirements of ASHRAE Standard 62 and any other specific equipment requirements discussed in DOE Order 6430.1A, Sections 1550-2.5 and 1550-99.0.

Basis: This is a requirement of DOE Order 6430.1A, which is a governing order for the project.

How the system meets the requirement: A portion of the process bay recirculation HVAC air (the makeup air) is drawn directly from outside. The make-up air and recirculation air of the system are drawn through an 85 -percent efficiency pre-filter prior to passing through two HEPA stages.

7. Requirement: Office and operational areas are maintained at temperatures recommended by the appropriate codes and standards, as required by DOE Order 6430.1 A, to ensure personnel comfort and safety and protect equipment during normal and upset conditions.

Basis: Temperature maintenance ensures personnel comfort and safety as well as protects equipment from temperature extremes that may cause it damage otherwise.

How the system meets the requirement: The HVAC systems maintain occupied rooms at no higher than $75^{\circ} \mathrm{F}$; and operational areas no higher than $85^{\circ} \mathrm{F}$, meeting DOE Order 6430.1A. 
8. Requirement: Radionuclides, non-radioactive air pollutants, and toxic air pollutants are emitted through the exhaust stack. Radioactive air emissions and monitoring are governed by U.S. Environmental Protection Agency regulations in 40 CFR 61 and Washington state regulations listed in WAC 246-247. Non-radioactive air pollutants are governed by the regulations listed in WAC 173-400. Toxic air pollutants are governed by regulations listed in WAC 173-460. All of these regulations specify emission limits and they require the use of emission control technology, as required.

Basis: The emissions from the CVDF are governed by U.S. Environmental Protection Agency and Washington State regulations, that require the use of emission control technology.

How the system meets the requirement: The stack monitoring system measures the levels of releases.

9. Requirement: Industrial ventilation design air quantities and transport velocities are calculated according to the calculation methods prescribed by the requirements in the ACGIH Industrial Ventilation Manual, ASHRAE Fundamentals, UBC 29, CFR 1910, NFPA 45, NFPA 90A, NFPA 91, and NFPA 801. Design heating and cooling load calculations are developed and presented as part of the design packages.

Basis: The process general supply/exhaust HVAC system design calculations for supply and exhaust of air should be performed in accordance with industry standard calculation methods.

How the system meets the requirement: Merrick HVAC calculations (Merrick 1996) were performed to the specified calculation methods. The Merrick HVAC calculations provide design heating and cooling load calculations.

10. Requirement: Velocities are determined in accordance with Section 5 of the ACGIH Industrial Ventilation Manual.

Basis: The system design, sizing, air flow, and velocity calculations for supply and exhaust of air should be performed to industry standards.

How the system meets the requirement: Merrick HVAC calculations (Merrick 1996) were performed to the HVAC design requirements and provide duct sizing, flow, volume, and velocity data.

11. Requirement: Duct thickness are determined by Tables 5.1, 5.2, 5.3, and 5.4 of ERDA76-21. All welded duct work has a minimum duct thickness of No. 16 U.S. gauge.

Basis: The process general supply/exhaust HVAC system fabrication should meet the requirements of ERDA-76-21. All duct work is 16 U.S. Standard Gauge 
How the system meets the requirement: The HVAC construction specification (15890) provides references to ERDA-76-21 for installation and function of HVAC duct.

12. Requirement: All ducting systems are classified as determined by the criteria in ERDA76-21, Table 5.5. Each duct system complies with the design and construction standards specified in ERDA-76-21 for the levels determined from Table 5.5. Acceptable leakage for each level of classification is no greater than the limits specified in Table 5.6 of ERDA-76-21.

Basis: The governing documentation for the project requires use of ERDA and other applicable codes and standards.

How the system meets the requirement: The Merrick HVAC calculations (Merrick 1996) provide the design calculations for the HVAC ducting. The HVAC construction specification (15890) references ERDA-76-21, Table 5.6, for the determination of maximum leak rates.

13. Requirement: Mechanical components for the CVDF are sized and selected according to the appropriate codes and standards.

Basis: This is requirement is based on usage of good engineering practices.

How the system meets the requirement: Mechanical components are sized and selected to meet the operational and functional requirements of the system as delineated in Section 3.1.

The materials requirements listed in Section 4.4 are applicable to the design of the process general supply/exhaust HVAC system. 
SNF-3081 Rev. 0

Table 3-1. Codes, Standards, and Source Documents that Apply to Cold Vacuum Drying Facility Piped System

\begin{tabular}{|l|l|l|l|}
\hline \multicolumn{1}{|c|}{ Category/Application } & \multicolumn{1}{|c|}{$\begin{array}{c}\text { Seneral Service SSCs } \\
\text { Safety-Significant } \\
\text { SSCs }\end{array}$} & $\begin{array}{c}\text { Class } \\
\text { SSCs }\end{array}$ \\
\hline $\begin{array}{l}\text { Chilled/cooling water systems } \\
\text { piping, valves, and pumps }\end{array}$ & $\begin{array}{l}\text { ANSI/ARI 550, 590 } \\
\text { ANSI/ASME B31.3, B31.5 } \\
\text { ASME VIII } \\
\text { ANSI/ASME B16 series }\end{array}$ & $\begin{array}{l}\text { Same as general service } \\
\text { ASME III* }\end{array}$ & ASME III* \\
\hline $\begin{array}{l}\text { Condensate, floor drain, and tanks } \\
\text { valves and tanks }\end{array}$ & $\begin{array}{l}\text { ANSI/ASME B31.3, } \\
\text { ANSI/AWWA-D100a }\end{array}$ & $\begin{array}{l}\text { Same as general service } \\
\text { ANSI/ASME B31.3 } \\
\text { ASME VIII } \\
\text { ANSI/ASME B16 series }\end{array}$ & ASME III* \\
\hline Reference air system & ANSI/ASME B31.3 service & Same as general service & ASME III* \\
\hline
\end{tabular}

Note: See Section 8.0 for a list of the references cited in this table.

*ASME, 1995, Boiler and Pressure Vessel Code, American Society of Mechanical Engineers, New York, New York, Section III, or comparable safety-related codes and standards that are appropriate for the system being designed.

CGA = Compressed Gas Association.

$\mathrm{SSC}=$ structure, system, and component.

\subsubsection{Chemical and Process}

No unique chemical and process requirements are applicable to this system.

\subsubsection{Electrical Power}

No unique normal operational electrical power requirements are applicable to this system. A standby power supply is provided to power the local exhaust system and reestablish local exhaust flow within 1 minute following a power loss.

\subsubsection{Instrumentation and Control}

1. Requirement: An interlocked HVAC control system is provided so that reversed airflow patterns cannot be established.

Basis: Prevention of reversed airflow patterns is essential for the HVAC system to perform its function and to prevent cross contamination or the release of contaminated air into occupied spaces. 


\section{How the system meets the requirement:}

- The process bay recirculation HVAC system has several interlocks to prevent reversed airflow. If the fire protection system detects smoke in the duct, an interlock cuts power to the supply fan and closes the isolation damper. The anti-backdraft damper, although not interlocked with any system, mechanically eliminates any reversed airflow from the process bay recirculation HVAC system to the outside air.

- $\quad$ The supply fan (HVAC-FAN-8005) is interlocked with the exhaust fans (HVAC-EXHF8025 and HVAC-EXHF-8027). If the exhaust fans fail, the interlock trips the supply fan, eliminating continued air supply and preventing pressurization of operation areas. This interlock is also triggered by detection of smoke in the HVAC general supply/exhaust system, and by a low temperature sensor designed to protect the $\mathrm{CHW}$ cooling coil from freezing.

\subsubsection{Computer Hardware and Software}

No unique computer hardware and software requirements are applicable to this system.

\subsubsection{Fire Protection}

1. Requirement: The thermal detectors are of the rate-compensated type connected to the fire alarm control panel and system exhaust fans. The temperature setting for the detector is $190^{\circ} \mathrm{F}$ within $8^{\circ} \mathrm{F}$. Upon detection, the fans are stopped and the dampers closed.

Basis: Thermal detectors are required to protect the HEPA filters from exposure to excessive heat.

How the system meets the requirement: The HVAC system thermal detectors are connected to the fire alarm and control panel. The control panel interlocks stop the fan and close the isolation damper.

2. Requirement: Design and installation of duct work and dampers comply with DOE Order 6430.1A, Section 1550-2.5.6, which requires compliance with NFPA 90A and Sheet Metal and Air Conditioning Contractors National Association.

Basis: DOE Order 6430.1A is a governing document for the project and compliance with the order is required.

How the system meets the requirement: The construction specification (15890) requires fabrication and installation in accordance with ANSI/NFPA 90A, SMACNA 1208, and SMACNA 1481. Design of the HVAC system is included in Merrick HVAC calculations (Merrick 1996). 
3. Requirement: The fire protection provided for the HEPA filter banks consists of thermal detectors installed upstream of the banks, fire screens, and isolation dampers in the duct work.

Basis: These are the governing national standards and codes for the HVAC and compliance is required.

How the system meets the requirement: Thermal detector XS 8020, as shown on Drawing H-1-83769, is located upstream of HEPA filter bank housing HVAC-F-8020.

4. Requirement: Fire dampers are provided in all supply return and exhaust air duct penetrations of fire-rated walls. Provisions are included for testing of dampers.

Basis: Fire dampers are installed to prevent the spread of fire and provide isolation.

How the system meets the requirement: The only wall in the CVD Facility with a 2 hour fire rating does not contain any dampers.

Requirement: HVAC meets the requirements of NFPA 90A, Air Conditioning and Ventilating Systems; and NFPA 90B, Warm Air Heating and Air Conditioning Systems, is used as appropriate.

Basis: These are the governing standards for the system and compliance is required.

How the system meets the requirement: Merrick HVAC calculations (Merrick 1996) were performed to size heating, cooling, and airflow requirements to meet ANSI/NFPA 90A and ANSI/NFPA 90B.

5. Requirement: Fire dampers are provided only where closure does not prevent the functioning of safety-class systems in fire-rated separations necessary for confinement. Operation may be by thermal link or automatically from the fire protection system.

Basis: This is requirement from DOE-STD-1020-94 in order to allow proper functioning of safety-class systems.

How the system meets the requirement: All isolation dampers are designed and qualified as defined in DOE-STD-1020-94.

6. Requirement: Filter plenums located inside process buildings are separated from all parts of the building and enclosed by two-hour, fire-rated construction.

Basis: WHC-SC-SNF-FHA-003, CVDF Fire Hazards Analysis, discusses this requirement. 
How the system meets the requirement: The two-hour, fire-rated construction for the process general supply/exhaust HVAC system filter plenum was not addressed in the rpocurment of the filter plenums. This issue is being addressed in the FHA.

\subsection{Testing And Maintenance Requirements}

\subsubsection{Testability}

1. Requirement: The air filtration housing design allows for routine in-place testing of HEPA filtration systems (filters, housings, and duct work) as outlined in ASME N510 (DOE Order 6430.1A, Section 1300-3.6).

Basis: Testing is necessary to verify the performance of the HEPA filtration system.

How the system meets the requirement: The process bay recirculation air filtration housings specify the use of a bag-in/bag-out style filter. Also specified is that filter housings are to have provisions for routine in-place testing of HEPA filtration systems.

2. Requirement: Duct maintainability and testability follow the guidelines outlined in the ERDA-76-21, Section 2.3.8.

Basis: The system must be tested and maintained in order to ensure proper performance.

How the system meets the requirement: The Merrick HVAC calculations (Merrick 1996) provide the design calculations for the HVAC ducting. The HVAC construction specification (15890) references ERDA-76-21, Table 5.6, for the determination of maximum leak rates.

3. Requirement: The air filtration housing design allows for routine in-place testing of HEPA filtration systems (filters, housings, and duct work) as outlined in ASME N510 (DOE Order 6430.1 A, Section 1300-3.6).

Basis: Testing is necessary to verify the performance of the HEPA filtration system.

How the system meets the requirement: The process general supply/exhaust HVAC system air filtration housings specify the use of a bag-in/bag-out style filter. Also specified is that filter housings are to have provisions for routine in-place testing of HEPA filtration systems. 


\subsubsection{Technical Safety Requirement-Required Surveillances}

TSRs are discusses in Section 3.1.5. TSR Surveillance Requirements will be detailed in HNF3673, CVDF Technical Safety Requirements, when issued.

\subsubsection{Non-Technical Safety Requirement Inspections and Testing}

1. Requirement: Fire dampers are tested in accordance with the requirements of ASTM E119 and listed by Underwriters' Laboratories or approved by Factory Mutual.

Basis: This requirement is part of ASTM E-119 and compliance is required.

How the system meets the requirement: This requirement is part of the procurement specification for fire dampers.

2. Requirement: HEPA filters have a minimum startup efficiency of 99.95 percent as evaluated by testing conducted in accordance with ASME N510.

Basis: System air filtration is accomplished by two installed stages of testable, $99.95 \%$ efficient HEPA filters.

How the system meets the requirement: The construction specification ( 15856 , Section 2.4.2) for HVAC systems specifies HEPA filters have a 99.95 percent minimum startup efficiency on removal of particles up to three microns. HEPA filters are tested to ANSI/ASME N510 standards to assure meeting the 99.95 percent efficiency criterion.

3. Requirement: HEPA filters have a clean resistance pressure drop not to exceed $250 \mathrm{~Pa}$ (1 in. w.g.) with a velocity of the air entering the filter of $1.27 \mathrm{~m} / \mathrm{sec}(250 \mathrm{ft} / \mathrm{min})$.

Basis: System air filtration is accomplished by two installed stages of testable, $99.95 \%$ efficient HEPA filter stages. HEPA filters should be tested to ANSI/ASME N510 standards to assure meeting the $99.95 \%$ efficiency criterion..

How the system meets the requirement: HEPA filter design and testing standards are specified in the procurement specification. HEPA filters are tested to ANSI/ASME N510 standards to assure meeting the 99.95 percent efficiency criterion. Filter specifications, testing, and facility air balance/flow adjustments ensure that the requirements will be met.

4. Requirement: HEPA filters are constructed and acceptance-tested in accordance with ASME N509, ASME N510, and ASME AG-1.

Basis: The HEPA filters should be in compliance with Nuclear Power Plant AirCleaning Units and Components and tested to meet $99.95 \%$ efficiency criterion.

How the system meets the requirement: HEPA filter procurement and testing requirements are specified in the HVAC procurement specification. All HEPA filters are 
constructed and acceptance-tested to ANSI/ASME N509, ANSI/ASME N510, and ANSI/ASME AG-1.

5. Requirement: Dampers comply with the requirements determined from Table 5.12 of ERDA-76-21. Duct systems serving the confinement areas of the facility are not acoustically treated.

Basis: The process bay recirculation HVAC system fire damper procurement specification requires that fire dampers be rated to Underwriters Laboratories-listed or Factory Mutual-approved specifications according to ASTM E-119. All duct work of the system has a protective coating applied to the interior surface.

How the system meets the requirement: The construction specification (15890) requires fabrication and installation in accordance with ANSI/NFPA 90A, SMACNA 1208, and SMACNA 1481. Design of the HVAC system and dampers is included in Merrick HVAC calculations (Merrick 1996).

6. Requirement: Fans are balanced and checked for harmonic vibration in accordance with ASME N509.

Basis: The process bay recirculation HVAC system equipment is designed and procured to facility design life requirements. System fan balancing is required to meet these system design life requirements.

How the system meets the requirement: The construction specification (15890) requires fabrication and installation in accordance with ANSI/NFPA 90A, SMACNA 1208 , and SMACNA 1481. Design of the HVAC system and dampers is included in Merrick HVAC calculations (Merrick 1996).

\subsubsection{Maintenance}

No unique maintenance requirements are applicable to this system.

\subsection{Other Requirements}

\subsubsection{Security and Special Nuclear Material Protection}

No security and SNM protection requirements are applicable to this system.

\subsubsection{Special Installation Requirements}

No special installation requirements are applicable to this system.

\subsubsection{Reliability, Availability, and Preferred Failure Modes}


1. Requirement: The system provides proper distribution of airflow throughout the facility during process system normal, upset, emergency, and facility maintenance activities, excluding loss of electrical power.

Basis: The CVDF HVAC systems should be designed to protect the environment and operational personnel during all possible system configurations. In the case of a loss of electrical power, this scenario would result in curtailment of normal operations.

Therefore, no releases can be caused by processing operations and the HVAC system does not need to operate during loss of power.

How the system meets the requirement: The system provides the negative pressure differential required to establish airflow within the facility from areas of lesser potential contamination to areas of higher potential contamination. During loss of power, system dampers fail closed to maintain confinement. The system is not required to function during seismic events.

\subsubsection{Quality Assurance}

The CVDF HVAC system fabrication quality assurance/control program is based on the safety classification of the SSCs as detailed in the Safety Equipment List (HNF-SD-SNF-SEL-002) and application of a graded approach as described in the Project Hanford Quality Assurance Program Description (HNF-MP-599).

\subsubsection{Miscellaneous}

No miscellaneous requirements are associated with this system. 


\subsection{SYSTEM DESCRIPTION}

The system operations and configuration descriptions presented in this section discuss HVAC features that satisfy the FSAR safety functions and functional requirements listed in Sections 2 and 3 of this SDD. Descriptions of system operation are summarized from SNF-2356, Spent Nuclear Fuels Cold Vacuum Drying Facility Operations Manual.

\subsection{Configuration}

\subsubsection{Description of System, Subsystems, and Major Components}

4.1.1.1 Administration Building HVAC System. The administration building HVAC system supplies a combination of recirculated and outside air to the CVDF administration building. The system circulates in excess of six air changes per hour and maintains the administration building at a positive pressure with respect to the CVDF transfer corridor.

Drawing H-1-82195, Cold Vacuum Drying Facility, HVAC Air Flow Diagram, Administration Area, shows the components of the administration building HVAC system.

4.1.1.2 Process Bay Recirculation HVAC System. This section describes the configuration of a typical process bay recirculation HVAC system, four of which are in the CVDF, one for each active process bay (bays numbered 2, 3, 4, and 5). Each process bay recirculation HVAC system supplies fresh air to a process bay while recirculating the bay's resident air. Each system consists of (listed in order) an outside air intake, isolation damper, volume control damper, backdraft damper, return air duct, pre-filter, two stages of HEPA filters, heating coils, cooling coils, supply fan, and ductwork.

Figure 4-2, Cold Vacuum Drying Facility HVAC System P\&ID, is highlighted to show the process bay recirculation HVAC system and its relationship to the other systems within the CVDF (see Drawings H-1-82196, sheets 1 and 2).

\subsubsection{Process Bay Local Exhaust HVAC and Process Vent System. The process bay} local exhaust HVAC and process vent system provides exhaust capability to remove contaminated gases from the four process bays, process hoods (one per bay, PV-HOOD-1*12), and process vents (five vents per bay: tank TW-TK-3*12, vacuum piping, interior of the MCO and two legs of the helium system). Confinement dampers are provided in hood ducts to prevent cross-contamination between the various areas when the system is not operating. The system is connected to the standby power system to allow for restart of the system within 1 minute of loss of normal power. All of the exhaust is drawn through a bank of filters. Each filter train includes two isolation dampers, one stage of pre-filters, two stages of HEPA filters, and three sections for HEPA filter testing. A fire screen/spark arrester and an airflow monitor precede the filter bank. The exhaust gases are drawn through the system by one of a pair of centrifugal 
SNF-3081 Rev. 0

Figure 4-1. Administration Building - HVAC System

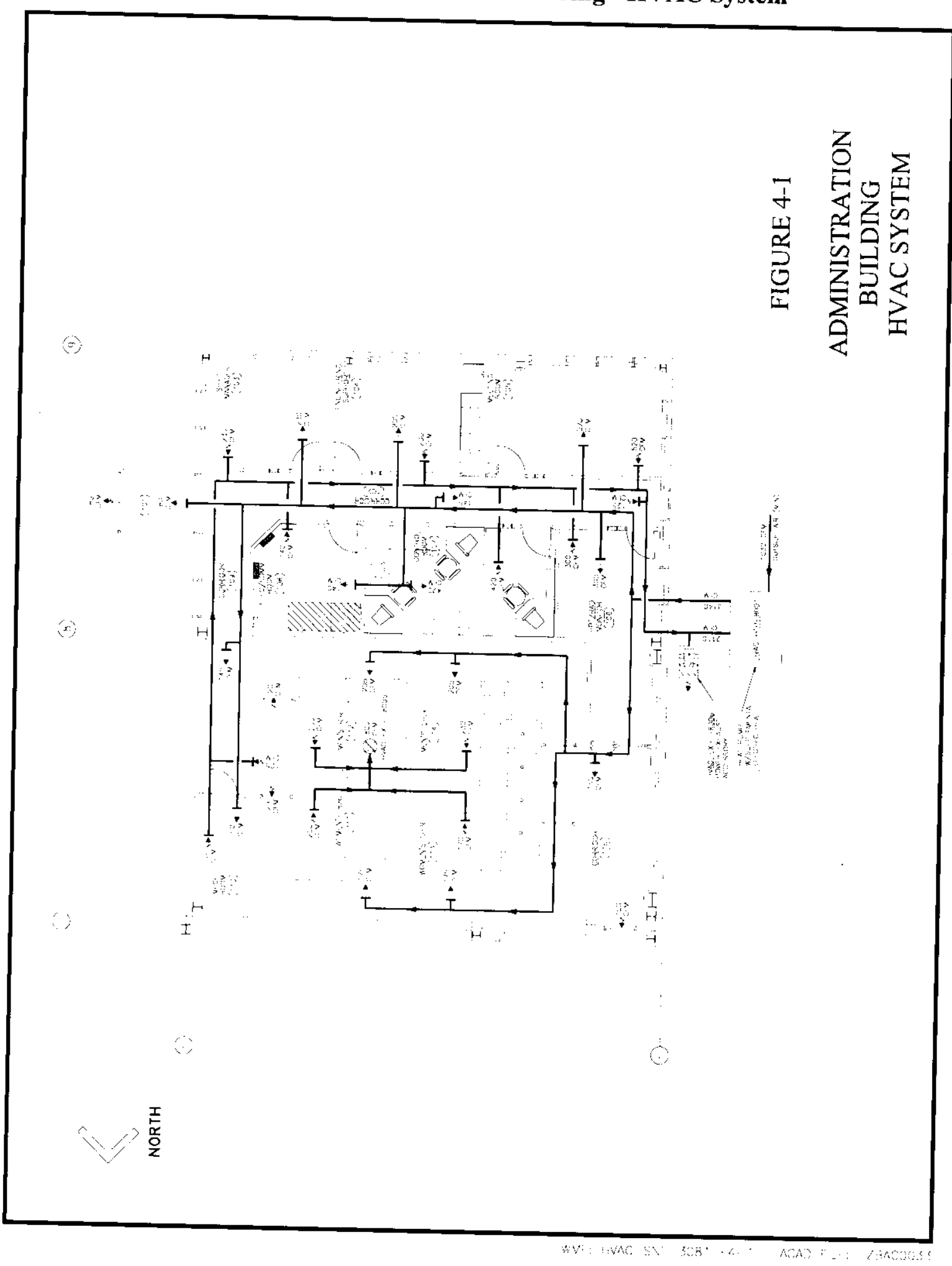




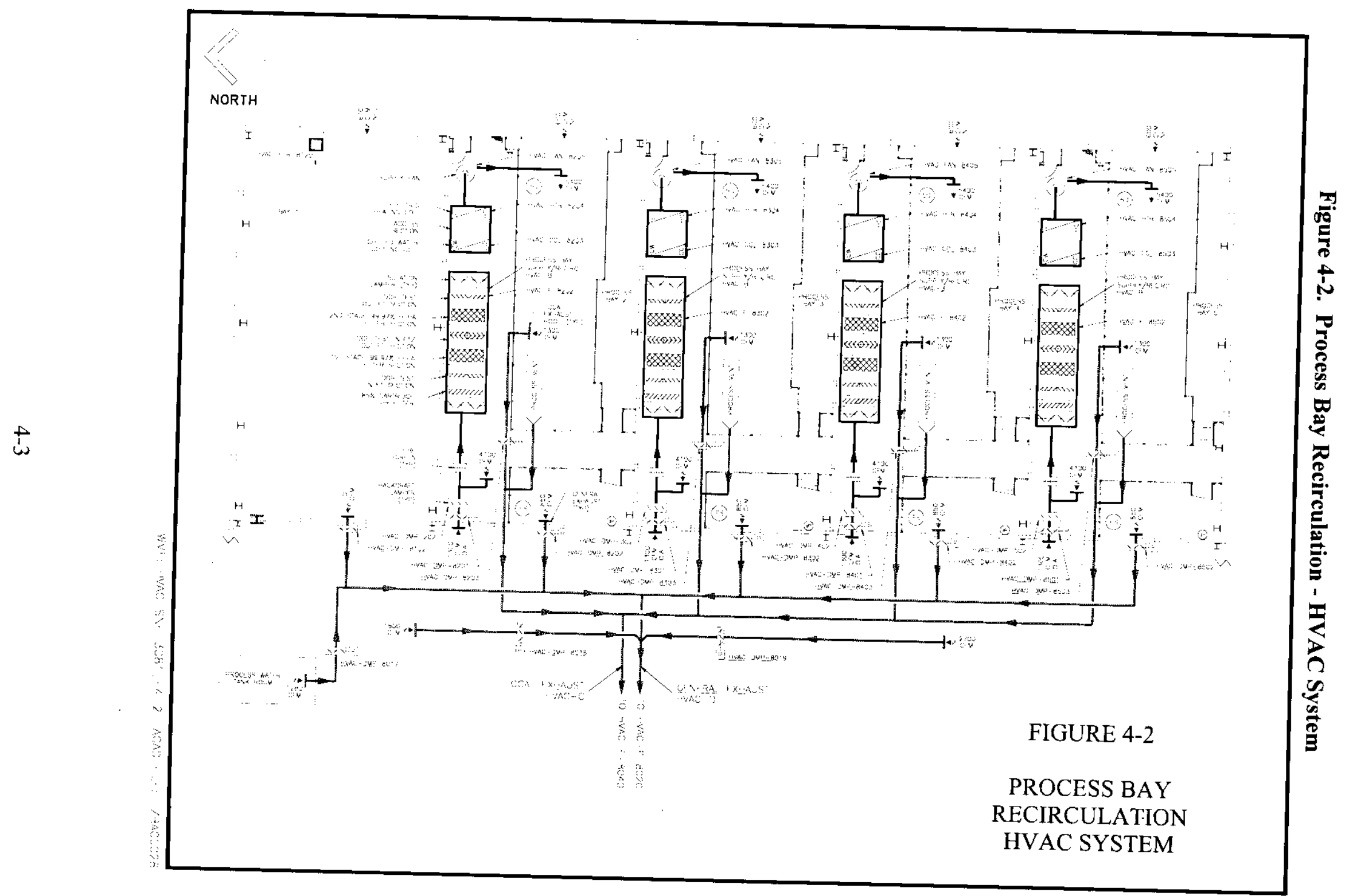

0
2
1
$\dot{0}$
0
0
0
0
0
0 
exhaust fans and discharged through the facility exhaust stack. Each of the exhaust fans is isolated from the exhaust stream by one manual intake damper and a backdraft damper.

Figure 4-3, Cold Vacuum Drying Facility HVAC System P\&ID, is highlighted to show the process bay local exhaust HVAC and process vent system and its relationship to the other systems within the CVDF (see Drawings H-1-82192 and H-1-82194).

4.1.1.4 Process General Supply/Exhaust HVAC System. The process general supply HVAC system supplies 100 percent outside air to the CVDF process areas, with the exception of the process bays that have dedicated supply air handling systems. The supply air is filtered and cooled or heated as required, to provide tempered air to the zones served.

The process general supply HVAC system consists of the outside air intake louver with isolation damper, the general supply air handling unit (HVAC-AHU-8002), and terminal electric heating coils. The terminal electric heating coils are used for zone heating. The process general exhaust HVAC system consists of the general exhaust final filter housing, the general exhaust fans, and barometric backdraft dampers. These dampers fail closed in the event of a system shutdown and fail-closed isolation dampers. The filter housing accommodates 85 percent efficient pre filters and two stages of HEPA filters. Two general exhaust fans are provided for redundancy.

Figure 4-4, Cold Vacuum Drying Facility HVAC System P\&ID, is highlighted to show the process general exhaust HVAC system and its relationship to the other systems within the CVDF facility (see Drawings H-1-82192, H-1-82193, and H-1-82194).

4.1.1.5 Reference Air System. The reference air system provides atmospheric air to 13 differential pressure transmitters/indicators located throughout the CVDF. The air is provided as a reliable reference to atmospheric pressure for each applicable room. The system is equipped with five valves that act as isolation points. These valves allow isolation of some or all of the differential pressure transmitters.

Figure 4-5, Cold Vacuum Drying Facility HVAC P\&ID, Facility Instrumentation, is highlighted to show the reference air system and its relationship to the other systems within the CVDF.

\subsubsection{Boundaries and Interfaces}

4.1.2.1 Administration Building HVAC System. The administration building HVAC system encompasses the entire administration area complex. The boundary at the west face (F Line) of the facility extends outside to encompass HVAC Air Handling Unit HVAC-HTP-8001 and sanitary discharge holding tank TK-9030. The boundary at the east face (E line) of the facility is the outdoors through the entry/exit alcove door. To the north ( 7 Line), the boundary is the doorway entering into the transfer corridor from corridor 115. 
SNF-3081 Rev. 0

Figure 4-3. Process Ba-y Local Exhaust HVAC and Process Vent System

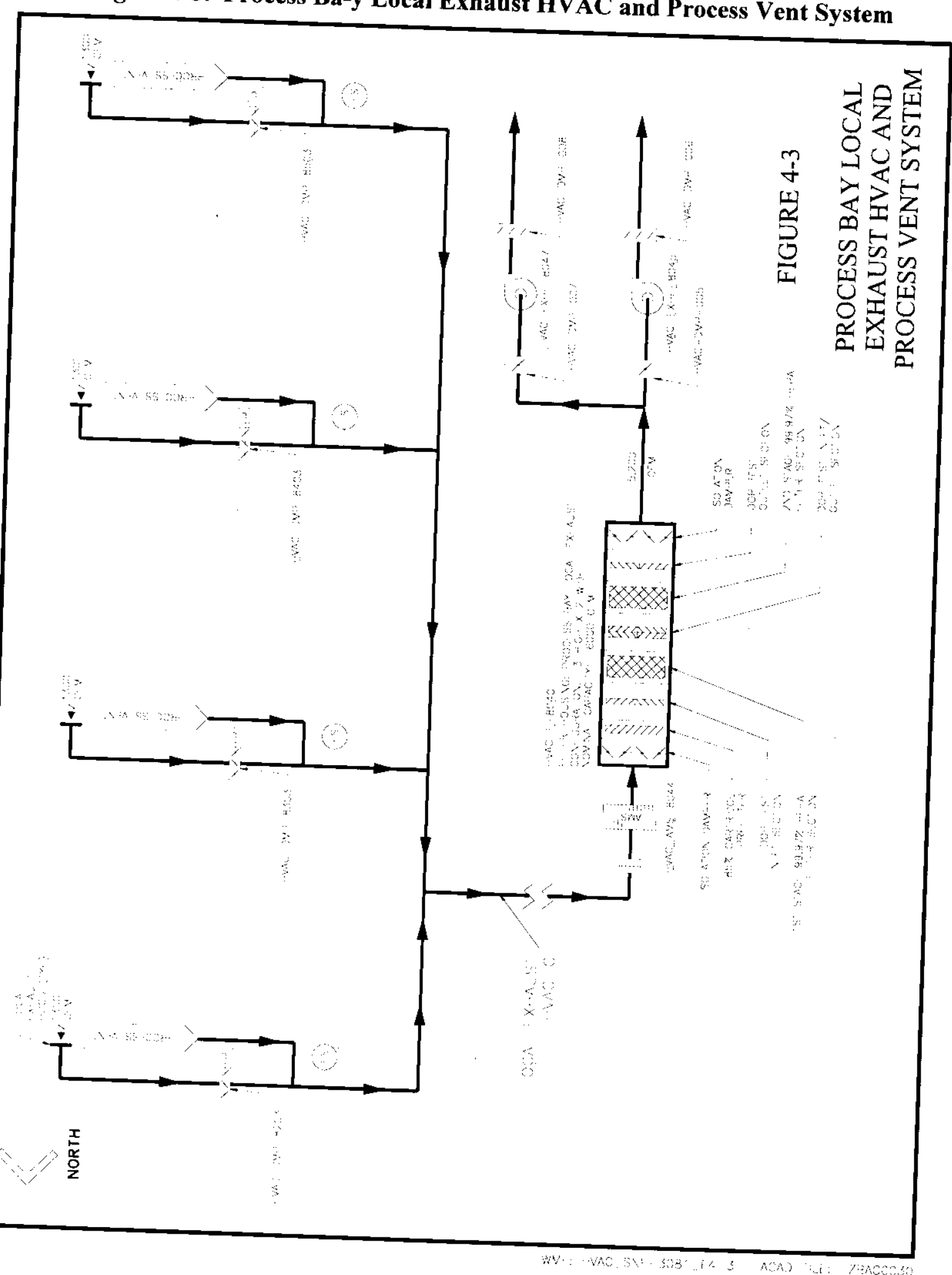


Figure 4-4. Process General Supply Exhaust - HVAC System

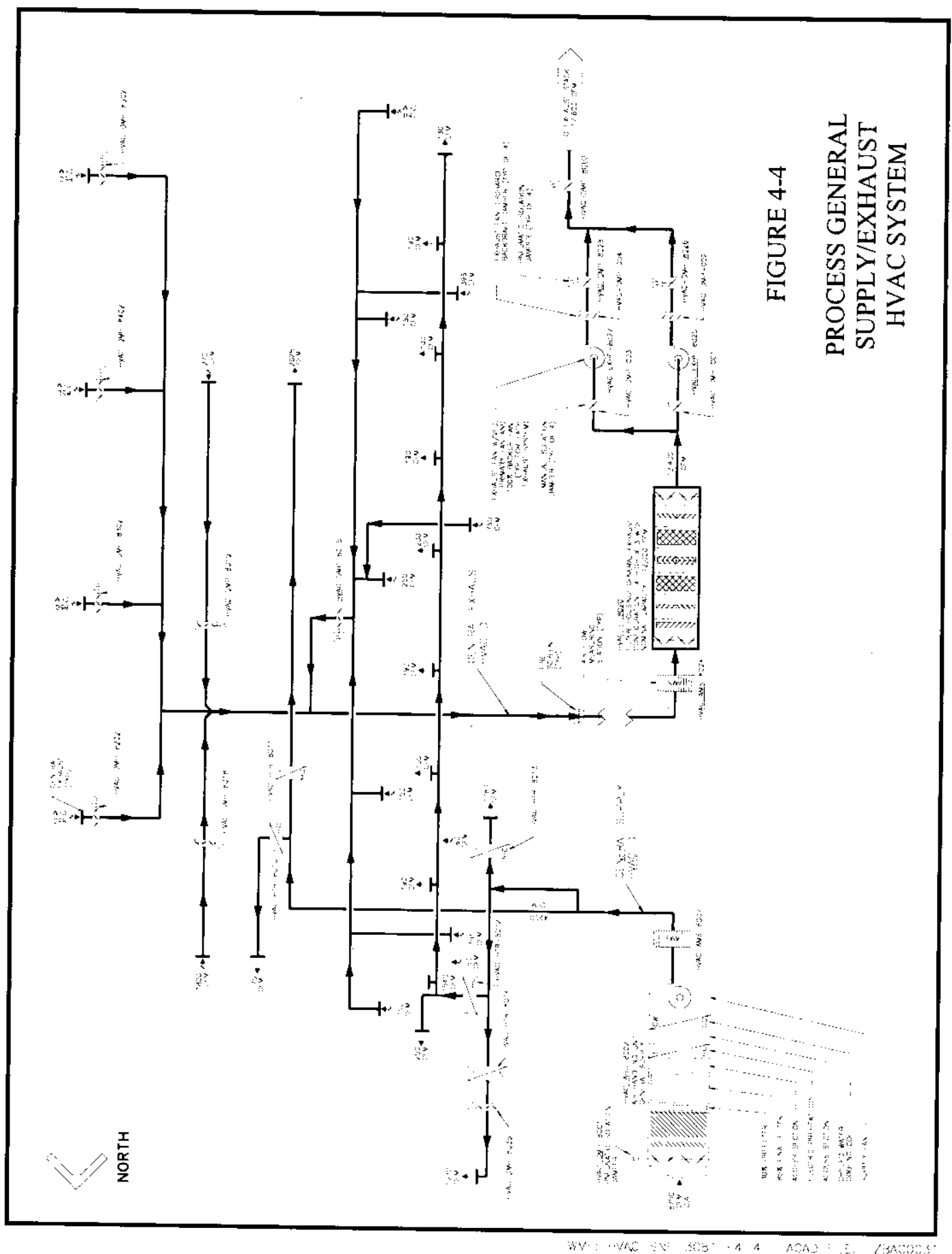

BEST AVAILABLE COPY 
SNF-3081 Rev. 0

Figure 4-5. Reference Air System

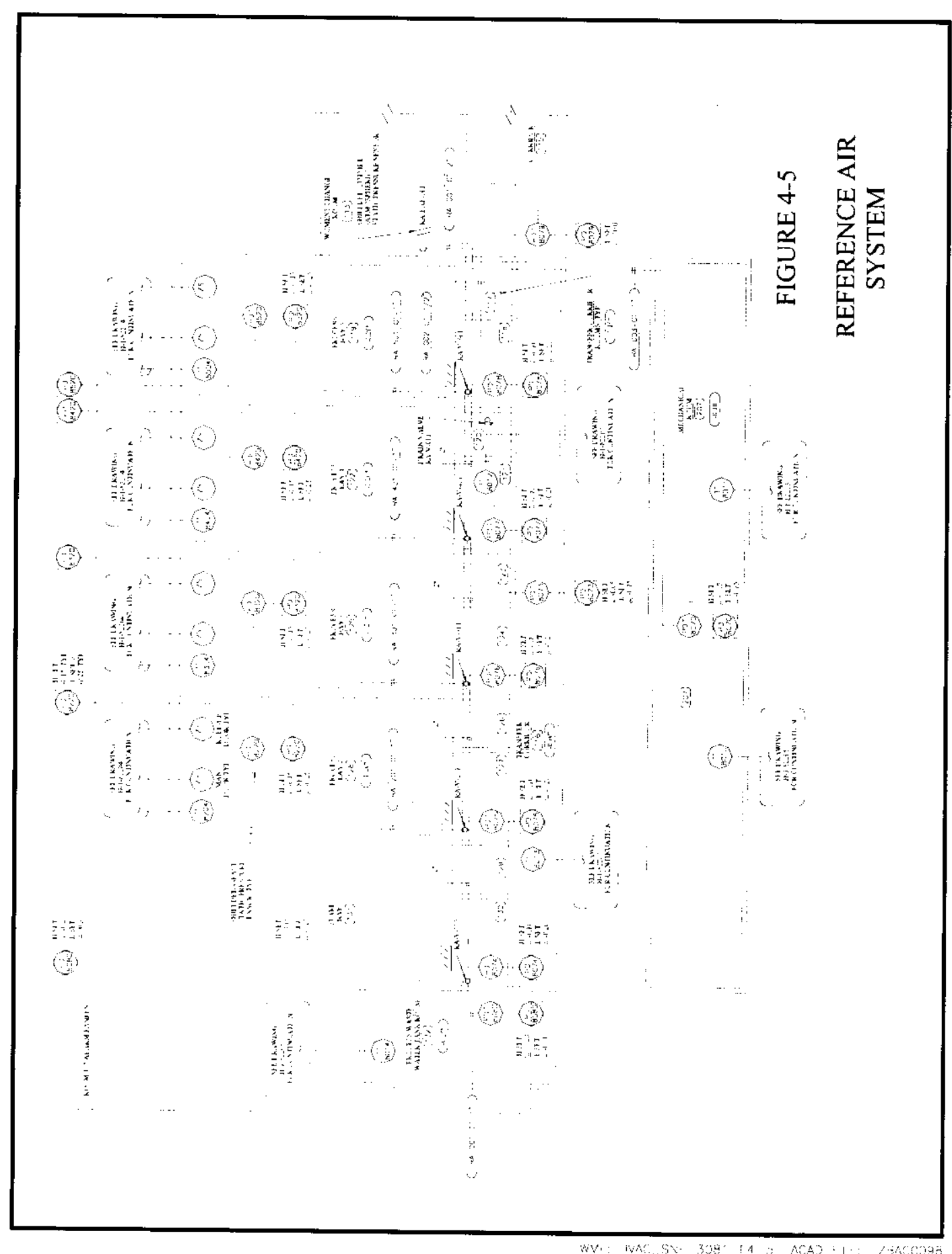


Fire Protection System Interface - Smoke in the HVAC supply air duct sensed by a smoke detector causes an indication at the fire alarm panel and the interlocked heat pump fan is shut down. The restroom exhaust fan shuts down upon detection of smoke in the duct, which shuts the damper.

MCS Interface - The administration building HVAC system maintains the control room temperature, where the MCS computer physically resides, within the pre-set temperature ranges to provide correct function for these controls.

4.1.2.2 Process Bay Recirculation HVAC System. The process bay recirculation HVAC systems have six major interfaces with CVD process:

Automatic Temperature Control System - This system provides the control devices, operators, sensors, low voltage wiring, software, and programming required to operate the general exhaust/supply system for the CVDF. The control panel is located in the control room. SDDSNF-3090 provides details on this system.

Electrical Power Distribution System - The process bay recirculation HVAC systems are supplied by normal distributed power consisting of single-phase $120 \mathrm{~V}, 60 \mathrm{~Hz}$, and three-phase $480 \mathrm{~V}, 60 \mathrm{~Hz}$ power feeds. The three-phase $480 \mathrm{~V}, 60 \mathrm{~Hz}$ power feeds the supply fan motor and the electric heating coil module for each process bay recirculation HVAC system. The singlephase $120 \mathrm{~V}, 60 \mathrm{~Hz}$ feed supplies the remaining power requirements for the process bay recirculation HVAC systems. SDD-SNF-3075 provides details on this system.

Compressed and Instrument Air System - The process bay recirculation HVAC systems interface with the compressed and instrument air system that supplies both compressed and instrument air to maintain temperature control, HVAC system balance, and containment damper alignment. Compressed and instrument air for the process bay recirculation HVAC systems is used to position HVAC and isolation dampers, and to operate the CHW cooling coil in AIR HANDLING UNIT. Compressed and instrument air is supplied to each bay via IA-*02-ST-1/4" and CA-*02-GCS-1/2" lines. (*takes the place of the bay number, example: IA-202-ST-1/4" is located in bay 2 ). SDD-SNF-3066 provides details on this system.

CHW System - The CHW supply provides $23.2 \mathrm{gal} / \mathrm{min}$ of $7.2^{\circ} \mathrm{C}\left(45^{\circ} \mathrm{F}\right)$ water to the AIR HANDLING UNIT cooling coils for each process bay recirculation HVAC system. CHW is supplied to process bays 2, 3, 4, and 5 through CHW supply lines CHW-201-CT-2", CHW-301CT-2", CHW-401-CT-2", and CHW-501-CT-2", respectively. After the CHW has run through the cooling coils, it is transferred out of process bays $2,3,4$, and 5 through $\mathrm{CHW}$ return lines CHW-202-CT-2", CHW-302-CT-2", CHW-402-CT-2", and CHW-502-CT-2", respectively. SDD-SNF-3086 provides details on this system.

Fire Protection System - As part of the fire protection system, each process bay recirculation HVAC system provides dampers that shut down when high temperatures are detected in the bay. The systems also provide smoke detectors downstream of the supply fan in each process bay. A signal from the affected detector triggers the interlock on the fan in the process bay. Fire 
protection of the building and operating system is described in detail in WHC-SD-SNF-FHA003, Fire Hazard Analysis for the Cold Vacuum Drying System Facility. SDD-SNF-3077 provides details on this system.

Effluent Drains System - The process bay recirculation supply HVAC system interfaces with tank CNDS-TK $-410^{*}$ in each process bay and collects the condensate from the cooling coils. SDD-SNF-3073 provides details on this system.

4.1.2.3 Process Bay Local Exhaust HVAC and Process Vent System. The process bay local exhaust HVAC and process vent system, including process hood, has six major interfaces with the CVDF. The local exhaust system includes a process bay isolation damper for each process bay (HVAC-DMP-8203, HVAC-DMP-8303, HVAC-DMP-8403, and HVAC-DMP-8503); a single fire screen downstream of the process bay isolation dampers; an air measuring station (HVAC-AMS-8044); a HEPA filter bank (HVAC-F-8040); two exhaust fans (a lead [HVACEXHF-8045] and a standby [HVAC-EXHF-8047]), and two backflow dampers (HVAC-DMP006 and HVAC-DMP-008), one for each exhaust fan.

Electrical Power Distribution System - The process bay local exhaust HVAC system is supplied by normal distributed power comprising single-phase $120 \mathrm{~V}, 60 \mathrm{~Hz}$, and three-phase $480 \mathrm{~V}, 60 \mathrm{~Hz}$ power feeds. The three-phase $480 \mathrm{~V}, 60 \mathrm{~Hz}$ power supplies the exhaust fans for the process local exhaust HVAC system. The single-phase $120 \mathrm{~V}, 60 \mathrm{hz}$ supplies the remaining power requirements for the process local exhaust HVAC system. A standby power supply is provided to power the local exhaust within 1 minute following a loss flow in the local exhaust system from a loss of power.

Automatic Temperature Control System - This system provides the control devices, operators, sensors, low voltage wiring, software, and programming required to operate the local exhaust and process vent system for the CVDF. The control panel is located in the control room.

The HVAC control system controls exhaust fans HVAC-EXHF-8045 and HVAC-EXHF-8047 and pneumatic dampers, HVAC-DMP-8203, HVAC-DMP-8303, HVAC-DMP-8403, and HVAC-DMP-8503. The control system controls the flow rate through the use of flow indicator control/transmitter HVAC-AMS-8044, which sends a signal to exhaust fan variable frequency drives VFD-8045 and VFD-8047. This adjusts flow based upon the input signal it receives.

The HVAC control system provides indication of system functions to the control panel. Flow switches FS-8*07 provide indication that minimum flow rates are available in the local exhaust ducts of each bay. There are power indicator lights on both exhaust fans (YL-8045 and YL8047).

The HVAC control system provides alarm indication to the control room. The system alarms on high and high-high differential pressure across the HEPA filters (PDAH-8040 and PDAHH8040). The system also alarms on low exit pressure from the HEPA filters. The exhaust fans have a differential pressure alarm annunciation associated with them (PDY-8045 and PDY8047). 
Compressed and Instrument Air System - Compressed and instrument air is supplied to process bay isolation dampers HVAC-DMP-8203, HVAC-DMP-8303, HVAC-DMP-8403, and HVAC-DMP-8503 to control their position (open or closed). Bay isolation damper actuators that cause the dampers to fail closed upon a loss of electrical power are each provided with a safetysignificant, $8.3 \mathrm{gal}$, compressed air reservoir to operate the damper during standby power operation.

Fire Protection System - Fire screens are installed on the local exhaust system duct prior to the filter housing. The local exhaust has a temperature indicator to monitor the rate of temperature rise that will shut down the fan in the event of a fire or high temperature in the filter housing.

4.1.2.4 Process General Supply/Exhaust HVAC System. The process general supply HVAC system is bounded by the air intake and exhaust locations for the system and includes all components that are required to condition the supply air.

The process general exhaust HVAC system is bounded by the air intake and exhaust locations for the system, and includes all components that are required to filter and exhaust process air. The process general supply/exhaust HVAC system has six major interfaces with the CVD process.

Automatic Temperature Control System - This system provides the control devices, operators, sensors, low voltage wiring, software, and programming required to operate the general exhaust/supply system for the CVDF. The control panel is located in the control room. The process general supply HVAC system fan and process general exhaust HVAC system fans are interlocked to prevent the supply fan from operating upon detection of failure of the exhaust air fans.

Electrical Power Distribution System - The process general supply/exhaust HVAC system is supplied by normal distributed power consisting of single-phase $120 \mathrm{~V}, 60 \mathrm{~Hz}$, and three-phase $480 \mathrm{~V}, 60 \mathrm{~Hz}$ power feeds. The three-phase $480 \mathrm{~V}, 60 \mathrm{~Hz}$ power supplies the supply and exhaust fans for the process general supply/exhaust HVAC system. The single-phase $120 \mathrm{~V}, 60 \mathrm{hz}$ feed supplies the remaining power requirements for the process general supply/exhaust HVAC system.

Compressed and Instrument Air System - Compressed and instrument air is supplied to process bay isolation dampers HVAC-DMP-8203, HVAC-DMP-8303, HVAC-DMP-8403, and HVAC-DMP-8503 to control their position (open or closed). Compressed and instrument air is supplied to temperature control systems and HVAC airflow balance system, as well as for containment damper alignment. Compressed and instrument air is supplied to the HVAC system at $690 \mathrm{kPa}\left(100 \mathrm{lb} / \mathrm{in}^{2}\right)$. The air is oil-free and dried to $-35^{\circ} \mathrm{F}$ with a pressure dew point based on $690 \mathrm{kPa}\left(100 \mathrm{lb} / \mathrm{in}^{2}\right)$ and $100^{\circ} \mathrm{F}$ ambient (HNF-SD-SNF-DRD-002). Compressed and instrument air for the process general supply/exhaust HVAC system is used mainly to position HVAC and isolation dampers and to operate the CHW cooling coil valve at the air handling unit.

CHW System - The CHW supply provides water to the air handling unit cooling coils for the process general supply HVAC system. The CHW system provides partial redundancy for CVD 
process support by using two split-system, air-cooled water chillers, CHW-CHR-7001, with condensing units. Each chiller is sized to accommodate 60 percent of the total facility requirements. CHW is supplied to the cooling coils by CHW-015- CT-3". This pipe is fed to CHW-022-CT-3". The discharged water is routed through CHW-023-CT-3" to CHW-016-CT$3 "$.

Fire Protection System - Smoke detector XS-8005 on the supply side signals the fire alarm and control panel, which signals MSTR-8005. This shuts down the supply fan and the exhaust fan. Fire protection of the building and operating system is described in detail in WHC-SD-SNFFHA-003.

Effluent Drains System - For the process general supply HVAC system, condensate is collected from air handling units in the mechanical room and is routed to a tank located in the transfer corridor.

4.1.2.5 Reference Air System. The boundary of the reference air system is between the point of reference and the bay pressure. The point of reference is located in the administration building; the bays and PWC room have pressure indication. This information is fed into the HVAC control system to determine the differential pressure between the bays and tank room.

\subsubsection{Physical Location and Layout}

4.1.3.1 Administration Building HVAC System. The administration building HVAC system consists of a packaged air-to-air heat pump/air handling unit, an economizer exhaust fan, power roof ventilators, ducting, and registers. The heat pump/air handling unit and economizer exhaust fan are located on the west side of the CVDF administration building. The power roof ventilator is located above the men's and women's changerooms and restrooms.

4.1.3.2 Process Bay Recirculation HVAC System. Each process bay recirculation HVAC system is contained completely within its process bay, except for the makeup air birdscreen, which is located outside of the building. The system is located on the second floor mezzanine of the process bay, affording easy access for maintenance of the system.

4.1.3.3 Process Bay Local Exhaust HVAC and Process Vent System. Each process vent hood is located within the process bay that it services along with the local exhaust intake for the process bay. The exhaust fans and filters for the system are located on the second floor of the transfer corridor in the mechanical room.

4.1.3.4 Process General Supply/Exhaust HVAC System. The components of the general process supply/exhaust HVAC system, with the exception of some ducting and exhaust registers, are located on the second floor of the transfer corridor in the mechanical room.

4.1.3.5 Reference Air System. The reference air system consists of a pipe header connected to an atmospheric static pressure sensor and 13 differential pressure transmitters in various locations throughout the facility. The system is routed from the administration building to the transfer corridor and into each of the process bays and the PWC tank room. 


\subsubsection{Principles of Operation}

4.1.4.1 Administration Building HVAC System. Outside air enters air-to-air heat pump/air handling unit HVAC-HTP-8001 at $1,030 \mathrm{ft}^{3} / \mathrm{min}$. This air is combined with $2,110 \mathrm{ft}^{3} / \mathrm{min}$ of recirculated administration building air. The air exits the air handling unit at $\sim 12.8^{\circ} \mathrm{C}\left(55^{\circ} \mathrm{F}\right)$ for cooling purposes and $\sim 26.1^{\circ} \mathrm{C}\left(79^{\circ} \mathrm{F}\right)$ for heating. The conditioned air is routed to each room in the administration building and discharged though supply diffusers. The supply diffusers in the administration building are (a) 24 in. by 24 in., lay-in style, louver-faced diffusers, or (b) a 12 in. by 12 in. surface-mounted, louver-faced diffuser equipped with opposed blade dampers. A manual damper is positioned upstream of each diffuser to allow for adjustment and balancing of the administration building HVAC system.

Administration building recirculation air is collected from the mechanical room (room 110), corridor (room 109), shift manager's office (room 103), electrical/communications room ( room 108), engineering support room (room 104), meeting room (room 105), and health physics technician room (106) through a return grille or register located in each area. Return grilles are (a) 12 in. by 12 in. or 12 in. by 24 in., lay-in, perforated face grilles, or (b) 12 in. by 12 in. return registers, surface-mounted, perforated-face grilles. Air is pulled from these areas by the heat pump fan and returned to the air handling unit for combination with outside air and recirculation through the building. The heat pump power exhaust that aids removal of building air during the economizing cycle, is a three-quarter horsepower fan that requires single-phase $480 \mathrm{~V}, 60 \mathrm{~Hz}$ power.

Air from the corridor (room 115) leading to the CVDF transfer corridor, men's and women's changerooms (rooms 114 and 113), and men's and women's restrooms (rooms 112 and 111) is not collected for recirculation. Pressure differentials are used to direct airflow from the corridor toward the CVDF transfer corridor; this is done to reduce the potential for spread of contamination from CVDF process areas. Air from the restrooms and changerooms (rooms 111 through 114) is pulled through exhaust registers by the power roof ventilator and exhausted to the outside at a rate of $800 \mathrm{ft}^{3} / \mathrm{min}$. Exhaust registers are $10 \mathrm{in}$. by $10 \mathrm{in}$., surface-mounted, exhaust registers equipped with opposed blade dampers.

4.1.4.2 Process Bay Recirculation HVAC System. Each process bay recirculation HVAC system draws makeup outside air through a louver with a birdscreen high on the west exterior of a process bay above the transfer corridor, an isolation damper (HVAC-DMP-8201, HVACDMP-8301, HVAC-DMP-8401, or HVAC-DMP-8501), a volume damper, and backdraft damper (HVAC-DMP-202, HVAC-DMP-302, HVAC-DMP-402, or HVAC-DMP-502). This air stream is blended with air recirculated from the west end of the process bay that is manually controlled through a volume damper. The combined air streams are then mixed through the process bay's filter housing, which contains a pre-filter and two HEPA filter stages (HVAC-F-8202, HVAC-F8302, HVAC-F-8402, or HVAC-F-8502); a CHW cooling coil (HVAC-CCL-8203, HVACCCL-8303, HVAC-CCL-8403, or HVAC-CCL-8503); and an electric heating coil (HVAC-HTR8204, HVAC-HTR-8304, HVAC-HTR-8404, or HVAC-HTR-8504). A supply fan (HVACFAN-8205, HVAC-FAN-8305, HVAC-FAN-8405, or HVAC-FAN-8505) is the last component in the system before the conditioned air is dispersed at the east end of the bay. 
The process bay re-circulation system runs continuously in an automatic mode. Damper location is operated to coincide with door location. The outside air damper is closed when the bay telescoping doors are open; this helps clean the air in the bays prior to closing the doors. The system is designed to fail safe with the outside air dampers closing upon loss of power to the facility.

4.1.4.3 Process Bay Local Exhaust HVAC and Process Vent System. The process bay local exhaust HVAC and process vent system provides $5,200 \mathrm{ft}^{3} / \mathrm{min}$ exhaust capability to remove contaminated gases from the four process bays, process hoods (one per bay, PV-HOOD-1*12), and process vents (five vents per bay: tank TW-TK-3*12, vacuum piping, interior of the MCO, and two legs of the helium system). Confinement dampers (HVAC-DMP-8203, HVAC-DMP8303, HVAC-DMP-8403, and HVAC-DMP-8503) are provided in process hood ducts to prevent cross-contamination between the various areas in the event of an exhaust system failure or when the system is not operating. A flow switch is located in each process bay local exhaust duct to monitor flow from each process hood. The switch is monitored through the HVAC control system and alarm when flow goes below $1,000 \mathrm{cfm}$. All of the exhaust is drawn through filter train HVAC-F-8040. The filter train includes two isolation dampers, one stage of pre-filters, two stages of HEPA filters (each stage is 99.97 percent efficient), and three sections for HEPA filter testing. A fire screen/spark arrester and an airflow monitor (HVAC-AMS-8044) precede the filter bank. The exhaust gases are drawn through the system by centrifugal exhaust fans (HVAC-EXHF-8045 or HVAC-EXHF-8047) and discharged through the facility exhaust stack. Each of the exhaust fans can be isolated from the exhaust stream by one manual intake damper (HVAC-DMP-005 and HVAC-DMP-007 and a backdraft damper (HVAC-PMP-006 and HVACPMP-008).

The local exhaust system runs continuously in an automatic mode. The system has redundant fans; in the event one fan goes down, the system will start the second fan and provide the operator with the information. Backup power is available to operate the local exhaust system. The backup power automatically starts the exhaust fan in the event of facility power loss. Local exhaust bay isolation dampers, that fail closed upon a loss of electrical power, are each equipped with a safety-significant, $8.3 \mathrm{gal}$, compressed air reservoir to operate the damper during standby (backup) power operation.

4.1.4.4 Process General Supply/Exhaust HVAC System. The process general supply HVAC system draws outside air through an intake louver located on the west exterior wall of the second floor mechanical room and an isolation damper (HVAC-DMP-8001) into air handling unit HVAC-AHU-8002 at a rate of $\sim 8,850 \mathrm{ft}^{3} / \mathrm{min}$. In the air handling unit, the air passes through a 30 percent pre-filter and an 85 percent final filter (HVAC-F-8002), over electric preheat coil HVAC-HTR-8003, and CHW cooling coil HVAC-CCL-8004. The preheat and cooling coils condition the air to the desired exit temperature, between $10^{\circ} \mathrm{C}\left(50^{\circ} \mathrm{F}\right)$ to $11.1^{\circ} \mathrm{C}\left(52^{\circ} \mathrm{F}\right)$. The air is exhausted from the air handling unit at $\sim 8,850 \mathrm{ft}^{3} / \mathrm{min}$ through supply fan HVAC-FAN8005. The supply fan is controlled by motor starter MSTR-8005. The supply air is provided to the process water tank room, mechanical room, transfer corridor, transfer corridor rooms, and process bays. 
The exhaust system draws air from the CVDF process areas at a combined rate of $\sim 12,450$ $\mathrm{ft}^{3} /$ min. This air stream is drawn from the process water tank room, mechanical room, transfer corridor, transfer corridor rooms, and process bays; outside air in-leakage to the process bays is $600 \mathrm{ft}^{3} / \mathrm{min}$ per bay and approximately $250 \mathrm{ft}^{3} / \mathrm{min}$ from the transfer corridor. This exhaust airflow rate is sufficient to maintain the desired process area negative pressure quantities, ranging from $-0.10 \mathrm{in}$. water to $-0.25 \mathrm{in}$. water. These negative pressures are provided to confine potential contamination. The pressures are such that airflow within the building moves from areas of lower potential contamination toward areas of higher potential contamination. The differential pressure instruments in each bay are interlocked through the HVAC control system to provide remote alarms.

Exhaust air ducts from the process bays and CVDF rooms are routed to a common exhaust duct. Flow through this duct is monitored by airflow measuring station HVAC-AMS-8024. The duct is routed to general exhaust filter HVAC-F-8020. The filter train includes two isolation dampers, one stage of pre-filters, two stages of HEPA filters (each stage is 99.97 percent efficient), and three sections for HEPA filter testing. The filtered airflows across manually-operated damper HVAC-DMP-001 or HVAC-DMP-003 and through an exhaust fan (HVAC-EXHF-8025 or HVAC-EXHF-8027). The exhaust fan is controlled by a variable frequency drive (VFD-8025 or VFD-8027). The air then flows across backdraft damper HVAC-DMP-002 or HVAC-DMP-004 and pneumatically-operated isolation damper HVAC-DMP-8026 or HVAC-DMP-8028. The isolation damper is designed to fail closed, providing confinement of potential contamination. The air is then discharged to the exhaust stack.

In the event that the lead exhaust fan is not operating, redundant manual damper HVACDMP003, exhaust fan HVAC-EXHF-8027, variable speed drive VFD-8027, backdraft damper HVAC-DMP-004, and isolation damper HVAC-DMP-8028 have been provided. The flow sequence and operation mode of the redundant exhaust train are identical to those of the lead train. This arrangement meets requirement 3.1.6.4.1 in Section 3.

Supply fan HVAC-FAN-8005 and exhaust fans HVAC-EXHF-8025 and HVAC-EXHF-8027 are interlocked to prevent the supply fan from operating upon detection of an exhaust air fan failure. This is done to prevent CVDF process area loss of negative pressure that would occur if air supply continued without adequate air exhaust; the subsequent pressurization would result in loss of confinement. In addition to failure of an exhaust air fan, a signal from smoke detector XS8005 upstream of air handling unit HVAC-AHU-8002 and a low temperature signal from temperature sensor TS-8005 on CHW cooling coil HVAC-CCL-8005 will trip the exhaust fan and activate the interlock.

Backdraft dampers located on the wall between the transfer corridor and the process bays allow $250 \mathrm{ft}^{3} / \mathrm{min}$ of airflow from each transfer corridor room into the process bays.

With the exception of air in-leakage, outside air for the system is provided through the intake louver located in the mechanical room. Air in-leakage, due to negative pressure relative to the environment, occurs through the process bay telescoping doors at a rate of $600 \mathrm{ft}^{3} / \mathrm{min}$, and accounts for a portion of the air exhausted from the process bays by the process general exhaust 
HVAC system. Additional minor air in-leakage occurs through the second floor mechanical room door; the flow rate is approximately $300 \mathrm{ft}^{3} / \mathrm{min}$.

4.1.4.5 Reference Air System. The reference air system allows atmospheric reference pressure to enter through RA-BAF-001 above the facility. The reference air system consists of a pipe header that is broken down into eight reference air lines. The atmospheric reference enters line RA-001-CT-2". In room 117, this line branches into RA-002-CT-1/2" and RA-003-CT-1". Line RA-003-CT-1" directs atmospheric reference to PDIT-8070 in the mechanical room (room 207). RA-002-CT- $1 / 2$ " directs atmospheric reference to six additional differential pressure transmitters: PDIT-8074 (transfer corridor [room 130]), PDIT-8075 (transfer corridor [room 127]), PDIT-8076 (transfer corridor [room 124]), PDIT-8077 (transfer corridor [room 121]), PDIT-8078 (transfer corridor [room 118]) and PDIT-8079 (transfer corridor). Additionally, RA002-CT-1/2" directs atmospheric reference to five other reference air lines: RA-001-CT-1", RA-201-CT-1", RA-301-CT-1", RA-401-CT-1", and RA-501-CT-1". Line RA-001-CT-1" directs atmospheric reference to PDIT-8080, which is located in the process waste water tank room (room 132). Line RA-201-CT-1" directs reference air into PDIT-8220 in process bay 2 (room 128), line RA-301-CT-1" directs reference air into PDIT-8320 in process bay 3 (room 125), line RA-401-CT-1" directs reference air into PDIT-8420 in process bay 4 (room 122), and lastly, line RA-501-CT-1" directs reference air into process bay 5 (room 119). This arrangement satisfies requirements 3.1.6.5.1 and 3.1.6.5.2 of Section 3.

The reference air system also contains nine temperature transmitters. These temperatures transmitters are contained in the control loops for the process bay recirculation and general air supply systems in the CVDF.

The temperature transmitters assist in the output of the system cooling coils or heating coils by providing a signal to the controllers that automatically controls the flow through the cooling coils or by modulating the heating coils and thus, reducing or increasing the temperature in the room.

\subsubsection{System Reliability}

The system reliability features for each of the HVAC and reference air systems are outlined below.

4.1.5.1 Administration Building HVAC System. The administration building HVAC system does not contain any redundant systems or components. The system is designed to accommodate 100 percent of the building heating/cooling requirements. The fail-safe operation of the system is to shut down.

4.1.5.2 Process Bay Recirculation HVAC System. The individual process bay recirculation HVAC systems in bays 2,3,4, and 5 do not contain any redundant components. At system shutdown, from an operational accident or seismic event, the outside isolation dampers HVACDMP-8*01 close and the fans HVAC-FAN-8*05 shut down.

4.1.5.3 Process Bay Local Exhaust HVAC and Process Vent System. The process bay local exhaust HVAC and process vent system contains redundant exhaust fans HVAC-EXHF-8047 
and HVAC-EXHF-8045. The system is equipped with a standby power that re-establishes flow in the local exhaust system after a facility power loss.

4.1.5.4 Process General Supply/Exhaust HVAC System. The process general supply/exhaust HVAC system contains redundant exhaust fans HVAC-EXHF-8027 and HVAC-EXHF-8025. The exhaust fans and supply fan are interlocked to prevent the supply fan from operating upon detection of an exhaust air fan failure. This is done to prevent CVDF process area loss of negative pressure, which would occur if air supply continued without adequate air exhaust. In addition, a signal from the smoke detector upstream of the air handling unit or a low temperature signal from the CHW cooling coil trips the supply fan and activates the interlock.

4.1.5.5 Reference Air System. The reference air system does not contain any redundant equipment.

\subsubsection{System Control Features}

4.1.6.1 System Monitoring--The ATC monitors the operating parameters and provides remote alarming in the control room for each system.

\subsubsection{Control Capability and Locations}

4.1.6.2.1 Administration Building HVAC System. The administration building HVAC system does not contain any manual operational controls.

4.1.6.2.2 Process Bay Recirculation HVAC System. The process bay recirculation HVAC system for each bay has a "Hand-Off-Auto" (HOA) station located at each supply fan. This is the only manual control included in the system. When the supply fan HOA station is in the "Auto" position, the ATC system controls the functioning of the cooling water and electric heating coils to maintain temperatures within the bay. The "On" position is used for fan testing only and for normal operations the switch is placed in the "Auto."

4.1.6.2.3 Process Bay Local Exhaust HVAC and Process Vent System. The process bay local exhaust HVAC and process vent system has a HOA station located at each exhaust fan. When the fan's HOA station is in the "Auto" position, the ATC system monitors and controls exhaust system. The "On" position is used for fan testing only and "Auto" is used for normal operations. The exhaust fans each have a manual isolation damper HVAC-DMP-005 and HVAC-DMP-007 that must be in the normally open position for proper operation of the system.

\subsection{Process General Supply/Exhaust System. The process general supply/exhaust} system has a HOA station located at each fan (supply and two exhaust fans) within the system. When the fan's HOA station is in the "Auto" position, the ATC system monitors and controls all parameters of the supply/exhaust system. The "On" position is used for fan testing only and the "Auto" position is used for normal operations. Each of the exhaust fans has a manual isolation damper HVAC-DMP-001 and HVAC-DMP-003 that must be in the normally open position for proper operation of the system. 
4.1.6.2.5 Reference Air System. The reference air system contains manual controls to place the system in operation. Each process bay contains a manual isolation valve for the reference air system. The valve must be open to allow atmospheric reference to differential pressure monitor in the process bay.

\subsubsection{Automatic and Manual Actions}

4.1.6.3.1 Administration Building HVAC System. No operator actions are required for normal operations of the administration building HVAC system. The system is under automatic control for the building's heating and cooling needs. The control system automatically controls operation of the administration building HVAC system heat pump, economizer exhaust fan, and roof ventilators. Calculations provide evidence that the equipment design and installation can meet the facility heating and cooling demands. General maintenance is conducted according to equipment manufacturer's recommendations.

4.1.6.3.2 Process Bay Recirculation HVAC System. Operator actions are not required for normal operation of the process bay recirculation HVAC system. The ATC system automatically controls the output of the system's heating and cooling coils. Facility operators are notified by the control system when filters are dust-loaded and require changing.

4.1.6.3.3 Process Bay Local Exhaust HVAC and Process Vent System. No operator actions are required for normal operation of the process bay local exhaust HVAC and process vent system. The ATC system automatically controls the output of the system heating and cooling coils. Facility operators are notified by the control system when filters are dust-loaded and require changing.

4.1.6.3.4 Process General Supply/Exhaust HVAC System. No operator actions are required for normal operation of the process general supply/exhaust HVAC system. The ATC system automatically controls the output of the system's heating and cooling coils. Facility operators are notified by the control system when filters are dust-loaded and require changing.

4.1.6.3.5 Reference Air System. No operator actions are required for normal operation of the reference air system.

\subsubsection{Setpoints and Ranges}

\subsection{Administration Building HVAC System}

Heat pump

HVAC-HTP-8001

$\left(62.5^{\circ} \mathrm{F}\right) \mathrm{wb}$ approximately $3,140 \mathrm{ft}^{3} / \mathrm{min}$

1.25 in w.g external static pressure at sea level

$3.0 \mathrm{HP}, 480 \mathrm{~V} / 3 / 60 \mathrm{~Hz}$ motor

Cooling Capacity:

Entering air temperature: $27.9^{\circ} \mathrm{C}\left(82.2^{\circ} \mathrm{F}\right) \mathrm{db}, 16.9^{\circ} \mathrm{C}$

Leaving air temperature: $12.8^{\circ} \mathrm{C}\left(55.0^{\circ} \mathrm{F}\right) \mathrm{db}, 11.1{ }^{\circ} \mathrm{C}$ 
$\left(52.0^{\circ} \mathrm{F}\right) \mathrm{wb}$

Heating Capacity:

Entering air temperature: $10.8^{\circ} \mathrm{C}\left(51.4^{\circ} \mathrm{F}\right) \mathrm{db}$

Leaving air temperature: $18.9^{\circ} \mathrm{C}\left(66.1^{\circ} \mathrm{F}\right) \mathrm{db}$

Exhaust fan

$3 / 4 \mathrm{HP}, 480 \mathrm{~V} / 1 / 60 \mathrm{~Hz}$ motor

HVAC-EXHF-8006

Power roof ventilator

approximately $800 \mathrm{ft}^{3} / \mathrm{min}$

HVAC-EXHF-8005

0.75 in w.g.

$3 / 4 \mathrm{HP}, 480 \mathrm{~V} / 3 / 60 \mathrm{~Hz}$ motor

Building setpoints:

Temperature setpoint

General building areas

Temperature setpoint

Restrooms/change rooms

Pressure setpoint

PDI 8079 $23.9^{\circ} \mathrm{C}\left(75^{\circ} \mathrm{F}\right)$ cooling

$22.2^{\circ} \mathrm{C}\left(72{ }^{\circ} \mathrm{F}\right)$ heating

$23.9^{\circ} \mathrm{C}\left(75^{\circ} \mathrm{F}\right)$ cooling

$23.9^{\circ} \mathrm{C}\left(75^{\circ} \mathrm{F}\right)$ heating

Low: +0.01 in. w.g.

4.1.6.4.2 Process Bay Recirculation HVAC System. The following system parameters and setpoints apply to each process bay recirculation system.

Supply fan: approximately $5,400 \mathrm{ft}^{3} / \mathrm{min}$

8.0 in. w.g. static pressure

$15 \mathrm{HP}, 480 \mathrm{~V} / 3 \varnothing / 60 \mathrm{HZ}$ MOTOR

Cooling coil: approximately $5,400 \mathrm{ft}^{3} / \mathrm{min}$

$116,000 \mathrm{Btu} / \mathrm{h}$

Entering air temperature: $26.7^{\circ} \mathrm{C}\left(80.1^{\circ} \mathrm{F}\right) \mathrm{db}, 16.4^{\circ} \mathrm{C}\left(61.6^{\circ} \mathrm{F}\right) \mathrm{wb}$

Leaving air temperature: $15.7^{\circ} \mathrm{C}\left(60.2^{\circ} \mathrm{F}\right) \mathrm{db}, 12.3^{\circ} \mathrm{C}\left(54.1^{\circ} \mathrm{F}\right) \mathrm{wb}$

Heating coil: approximately $5,400 \mathrm{ft}^{3} / \mathrm{min}$

$161,700 \mathrm{Btu} / \mathrm{h}$

$47.4 \mathrm{~kW}, 480 \mathrm{~V} / 3 \varnothing / 60 \mathrm{hz}$

Entering air temperature:

Leaving air temperature:

Bay temperature setpoint: $\quad 23.9^{\circ} \mathrm{C}\left(75^{\circ} \mathrm{F}\right)$ cooling $22.2^{\circ} \mathrm{C}\left(72{ }^{\circ} \mathrm{F}\right)$ heating

Filter differential pressure alarm setpoints:

Prefilter High: 1.0 in. water 
High-high: 1.5 in. water

First HEPA

Second HEPA
High: 3.0 in. water

High-high: 4.0 in. water

High: 2.0 in. water

High-high: 3.0 in. water

4.1.6.4.3 Process Bay Local Exhaust HVAC and Process Vent System. Normal capacity of filter bank is $5,200 \mathrm{ft}^{3} / \mathrm{min}$.

Filter alarms:

Pre-filter

High: 1.0 in. water gage

High-high: 1.5 in water gage

First HEPA High: 3.0 in. water gage

High-high: 4.0 in water gage

Second HEPA High: 2.0 in. water gage

High-high: 3.0 in water gage

Filters are changed when a radiation level of $200 \mathrm{mrem} / \mathrm{h}$ is reached in the filter housing.

4.1.6.4.4 Process General Supply/Exhaust HVAC System. Air handling unit HVAC-AHU8002 .

Supply fan: $\quad$ approximately $8,750 \mathrm{ft}^{3} / \mathrm{min}$

4.0 w.c. static pressure

$10.0 \mathrm{HP}, 480 \mathrm{~V} / 3 \varnothing / 60 \mathrm{HZ}$ MOTOR

Cooling coil: $\quad 376 \mathrm{MBH}(113 \mathrm{~kW})$

Entering air temperature: $36.1{ }^{\circ} \mathrm{C}\left(97^{\circ} \mathrm{F}\right) \mathrm{db}, 19.4{ }^{\circ} \mathrm{C}\left(67^{\circ} \mathrm{F}\right)$ wb

Leaving air temperature: $15^{\circ} \mathrm{C}\left(59^{\circ} \mathrm{F}\right) \mathrm{db}, 11.1{ }^{\circ} \mathrm{C}\left(52^{\circ} \mathrm{F}\right)$ wb

Heating coil: $\quad 385 \mathrm{MBH}(113 \mathrm{kw})$

Entering air temperature: $-12.8^{\circ} \mathrm{C}\left(9^{\circ} \mathrm{F}\right)$

Leaving air temperature: $10^{\circ} \mathrm{C}\left(50^{\circ} \mathrm{F}\right)$

Zone Terminal Heating Coils

HVAC-HTR-8010

Mechanical room

North approximately $1,575 \mathrm{ft}^{3} / \mathrm{min}$

$58.5 \mathrm{MBH}(17.2 \mathrm{~kW})$

$480 \mathrm{~V} / 3 / 60 \mathrm{hz}$

Setpoint $29.4{ }^{\circ} \mathrm{C}\left(85^{\circ} \mathrm{F}\right)$ 


\begin{tabular}{|c|c|c|}
\hline & HVAC-HTR-801 1 & approximately $2,625 \mathrm{ft}^{3} / \mathrm{min}$ \\
\hline & Mechanical room & $97.5 \mathrm{MBH}(28.6 \mathrm{kw})$ \\
\hline South & & $\begin{array}{l}480 \mathrm{~V} / 3 \oslash / 60 \mathrm{HZ} \\
\text { Setpoint } 29.4^{\circ} \mathrm{C}\left(85^{\circ} \mathrm{F}\right)\end{array}$ \\
\hline & HVAC-HTR-8012 & approximately $1,540 \mathrm{ft}^{3} / \mathrm{min}$ \\
\hline & Transfer corridor & $65.8 \mathrm{MBH}(17.9 \mathrm{kw})$ \\
\hline Rooms & & $\begin{array}{l}480 \mathrm{~V} / 3 \varnothing / 60 \mathrm{HZ} \\
\text { Setpoint } 31.5^{\circ} \mathrm{C}\left(88.8^{\circ} \mathrm{F}\right)\end{array}$ \\
\hline & HVAC-HTR-8013 & $1,780 \mathrm{ft}^{3} / \mathrm{min}$ \\
\hline & Transfer corridor & $\begin{array}{l}61.3 \mathrm{MBH}(19.4 \mathrm{kw}) \\
480 \mathrm{~V} / 3 \oslash / 60 \mathrm{HZ} \\
\text { Setpoint } 29.4^{\circ} \mathrm{C}\left(85^{\circ} \mathrm{F}\right)\end{array}$ \\
\hline & HVAC-HTR-8014 & $1,230 \mathrm{ft}^{3} / \mathrm{min}$ \\
\hline & PWC room & $45.7 \mathrm{MBH}(13.4 \mathrm{kw})$ \\
\hline & & $\begin{array}{l}480 \mathrm{~V} / 3 \varnothing / 60 \mathrm{hz} \\
\text { Setpoint } 29.4^{\circ} \mathrm{C}\left(85^{\circ} \mathrm{F}\right)\end{array}$ \\
\hline
\end{tabular}

General Exhaust Fans

HVAC-EXHF-8025 approximately $12,400 \mathrm{ft}^{3} / \mathrm{min}$ ea. 12.0 in. w.c. static pressure $30 \mathrm{HP}, 480 \mathrm{~V} / 3 \otimes / 60 \mathrm{HZ}$ Class II

HVAC-EXHF-8027 approximately $12,400 \mathrm{ft}^{3} / \mathrm{min}$ ea. 12.0 in. w.c. static pressure $30 \mathrm{HP}, 480 \mathrm{~V} / 3 \varnothing / 60 \mathrm{HZ}$

Class II

Filter differential pressure alarm setpoints:

Air handling unit pre-filter

Air handling unit final filter

Exhaust pre-filter

Exhaust first HEPA filter

Exhaust second HEPA filter
High: 1.0 in. water

High: 1.5 in. water

High: 1.0 in. water High-high: 1.5 in. water

High: 3.0 in. water High-high: 4.0 in. water High: 2.0 in. water 
High-high: 3.0 in. water

4.1.6.4.5 Reference Air System. The reference air system pressure transmitters/indicators parameters and setpoints are listed in Table 4-1.

4.1.6.5 Interlocks, Bypasses, and Permissives. The systems interlocks, bypasses, and permissives are listed below and described in detail in Appendix S of SNF-2356, Rev 1., Cold Vacuum Drying Facility Operations Manual.

4.1.6.5.1 Administration Building HVAC System. Upon detection of smoke, the supply and exhaust fans shut down.

4.1.6.5.2 Process Bay Recirculation HVAC System. The FCS initiates an automatic start sequence after a loss of power.

The process bays outside isolation damper, HVAC-DMP- $*^{*} 01$, is hardwired and interlocked with supply fan PDIS-8*05 and fail-closed upon indication of no differential pressure.

Upon detection of smoke at smoke detector XS- $8^{*} 05$, the supply fan will turn off and outside air isolation damper HVAC-DMP-8*01 closes.

Upon alarm from the process bay radiation area or continuous air monitors the outside air, isolation damper HVAC-DMP-8*01 closes. 
SNF-3081 Rev. 0

Table 4-1. Pressure Transmitter/Indicator Parameters and Setpoints

\begin{tabular}{|c|c|c|c|}
\hline $\begin{array}{c}\text { Pressure } \\
\text { Transmitter/Indicator }\end{array}$ & Room Number & $\begin{array}{c}\text { Room Design Space } \\
\text { Pressure Relative to } \\
\text { Atmosphere (in.) }\end{array}$ & $\begin{array}{l}\text { Alarm points: } \\
\text { High and Low } \\
\text { (in.) }\end{array}$ \\
\hline PDIT-8070 & $\begin{array}{l}\text { Mechanical room } \\
\quad(\text { Room 207) }\end{array}$ & -0.10 & $\begin{array}{l}\text { High: }-0.05 \\
\text { Low: }-0.15\end{array}$ \\
\hline PDIT-8073 & Room 116 & -0.10 & $\begin{array}{l}\text { High: }-0.05 \\
\text { Low: }-0.15\end{array}$ \\
\hline PDIT-8074 & Room 130 & -0.15 & $\begin{array}{l}\text { High: }-0.10 \\
\text { Low: }-0.20\end{array}$ \\
\hline PDIT-8075 & Room 127 & -0.15 & $\begin{array}{l}\text { High: }-0.10 \\
\text { Low: }-0.20\end{array}$ \\
\hline PDIT-8076 & Room 124 & -0.15 & $\begin{array}{l}\text { High: }-0.10 \\
\text { Low: }-0.20\end{array}$ \\
\hline PDIT-8077 & Room 121 & -0.15 & $\begin{array}{l}\text { High: }-0.10 \\
\text { Low: }-0.20\end{array}$ \\
\hline PDIT-8078 & Room 118 & -0.15 & $\begin{array}{l}\text { High: }-0.10 \\
\text { Low: }-0.20\end{array}$ \\
\hline PDIT-8079 & Room 115 & -0.15 & $\begin{array}{l}\text { High: ----..- } \\
\text { Low: }+0.01\end{array}$ \\
\hline PDIT-8080 & $\begin{array}{c}\text { Process waste water tank } \\
\text { room } \\
\text { (room 132) }\end{array}$ & -0.25 & $\begin{array}{l}\text { High: }-0.20 \\
\text { Low: }-0.30\end{array}$ \\
\hline PDIT-8220 & $\begin{array}{l}\text { Process bay } 2 \\
\text { (room 128) }\end{array}$ & -0.20 & $\begin{array}{l}\text { High: }-0.15 \\
\text { Low: }-0.25\end{array}$ \\
\hline PDIT-8320 & $\begin{array}{l}\text { Process bay } 3 \\
\text { (room 125) }\end{array}$ & -0.20 & $\begin{array}{l}\text { High: }-0.15 \\
\text { Low: }-0.25\end{array}$ \\
\hline PDIT-8420 & $\begin{array}{l}\text { Process bay } 4 \\
\text { (room 122) }\end{array}$ & -0.20 & $\begin{array}{l}\text { High: }-0.15 \\
\text { Low: }-0.25\end{array}$ \\
\hline PDIT-8520 & $\begin{array}{l}\text { Process bay } 5 \\
\text { (room 119) }\end{array}$ & -0.20 & $\begin{array}{l}\text { High: }-0.15 \\
\text { Low: }-0.25\end{array}$ \\
\hline
\end{tabular}


SNF-3081 Rev. 0

Table 4-2. Temperature Transmitter Parameters and Setpoints

\begin{tabular}{|c|c|c|c|}
\hline $\begin{array}{l}\text { Temperature } \\
\text { Transmitter }\end{array}$ & Exhaust System Interface & Room & $\begin{array}{l}\text { Alarm Points: } \\
\text { High and Low } \\
\qquad(\mathrm{C})\end{array}$ \\
\hline TT-8010 & General supply & $\begin{array}{l}\text { Mechanical room } \\
\quad \text { (room 207) }\end{array}$ & $\begin{array}{l}\text { High: } 85 \\
\text { Low: } 72\end{array}$ \\
\hline TT-8011 & General supply & $\begin{array}{l}\text { Mechanical room } \\
\quad(\text { room 207) }\end{array}$ & $\begin{array}{l}\text { High: } 85 \\
\text { Low: } 72\end{array}$ \\
\hline TT-8012 & General supply & room 121 & $\begin{array}{l}\text { High: } 75 \\
\text { Low: } 72\end{array}$ \\
\hline TT-8013 & General supply & $\begin{array}{l}\text { Transfer corridor } \\
\text { (room 116) }\end{array}$ & $\begin{array}{l}\text { High: } 75 \\
\text { Low: } 72\end{array}$ \\
\hline TT-8014 & General supply & $\begin{array}{c}\text { Process waste water tank } \\
\text { room } \\
\text { (room 132) }\end{array}$ & $\begin{array}{l}\text { High: } 75 \\
\text { Low: } 72\end{array}$ \\
\hline TT-8204 & Process bay local & $\begin{array}{c}\text { Process bay } 2 \\
\text { (room 128) }\end{array}$ & $\begin{array}{l}\text { High: } 75 \\
\text { Low: } 72\end{array}$ \\
\hline TT-8304 & Process bay local & $\begin{array}{l}\text { Process bay } 3 \\
\text { (room 125) }\end{array}$ & $\begin{array}{l}\text { High: } 75 \\
\text { Low: } 72\end{array}$ \\
\hline TT-8404 & Process bay local & $\begin{array}{l}\text { Process bay } 4 \\
\text { (room 122) }\end{array}$ & $\begin{array}{l}\text { High: } 75 \\
\text { Low: } 72\end{array}$ \\
\hline TT-8504 & Process bay local & $\begin{array}{l}\text { Process bay } 5 \\
\text { (room 119) }\end{array}$ & $\begin{array}{l}\text { High: } 75 \\
\text { Low: } 72\end{array}$ \\
\hline
\end{tabular}

Upon sensing temperatures of $40^{\circ} \mathrm{F}$ at TT8*05, an alarm is sent to the ATC system in the control room.

Upon sensing the exterior door position is open, the ATC system closes the outside air isolation damper, HVAC-DMP-8*01. The unaffected bays continue to operate with no intervention.

4.1.6.5.3 Process Bay Local Exhaust HVAC and Process Vent System. The ATC system initiates an automatic start sequence after resuming power after a loss of power. The local exhaust is supplied with a standby power source that re-establishes flow in the local exhaust within 1 minute from loss of power.

Upon loss of the operating exhaust fan, an alarm is issued to the ATC system and the backup fan is automatically started.

An alarm is issued to the ATC system when the humidity sensor located before the HEPA filter reaches a relative humidity of 70 percent. 
A flow switch is installed in the local exhaust duct prior to HVAC-DMP-8*03 in each bay. The ATC system alarms at flow rates less then $1,000 \mathrm{cfm}$.

Each stage of filtration is actively monitored for pressure drop. High differential conditions alarm on the ATC system in the control room.

Upon detection of temperatures of $190^{\circ} \mathrm{F}$ or a rate of rise of $30^{\circ} \mathrm{F}$ in 10 seconds, the exhaust fan is shut down.

The system is shut down by operator command at the HVAC control system work station. This action shuts down the operating fan and closes the isolation dampers.

4.1.6.5.4 Process General Supply/Exhaust HVAC System. The ATC system initiates an automatic start sequence after resuming power after a loss of power.

Upon detection of temperatures of $190^{\circ} \mathrm{F}$ or a rate of rise of $30^{\circ} \mathrm{F}$ in 10 seconds, the exhaust fan is shut down.

Upon loss of the operating exhaust fan, an alarm is issued to the ATC system and the backup fan is automatically started.

The freezestat, TE8005, will stop the general supply fan and close isolation damper HVACDMP-8001 upon sensing a temperature of $40^{\circ} \mathrm{F}$ and alarm at the ATC system in the control room.

An alarm is issued to the ATC system when the humidity sensor located before the HEPA filter reaches a relative humidity of 70 percent.

Differential pressure in the process bays and PWC tank room is monitored and alarmed in the control room.

Each stage of filtration is actively monitored for pressure drop. High differential conditions alarm on the ATC system in the control room.

Upon detection of smoke at smoke detector XS-8*05, the supply fan turns off and the outside air isolation damper HVAC-DMP- $8 * 01$ closes. The general exhaust fans remain running.

The process general supply HVAC system fan and the process general exhaust HVAC system fans are interlocked, preventing the supply fan from operating upon detection of exhaust air fan failure.

Confinement isolation dampers are provided on all duct branches connecting to the exhaust system to prevent backflow of air in the event of exhaust system shutdown. Confinement isolation dampers are also provided on the outside air intake and tank room supply duct to prevent backflow in the event of supply system shutdown. Fail-closed backdraft dampers are also installed between the transfer corridor and the process bays. 
SNF-3081 Rev. 0

4.1.6.5.5 Reference Air System. Not applicable.

\subsection{Operations}

Test specifications will be developed to identify factory acceptance, construction acceptance, and pre-operational test procedures. Additional information relating to specifications and procedures will be added when available.

\subsubsection{Initial Configurations}

\subsubsection{System Startup}

\subsubsection{Normal Operations}

\subsubsection{Off-Normal Operations}

\subsubsection{System Shutdown}

\subsubsection{Safety Management Programs and Administrative Controls}

The safety management programs and administrative controls for this SDD will be integrated into the SNF Project Integrated Safety Management System.

\subsection{Testing And Maintenance}

\subsubsection{Temporary Configurations}

There are no temporary configurations for any of the CVDF HVAC and reference air systems.

\subsubsection{Technical Safety Requirement-Required Surveillances}

Routine radiation monitoring of the facility includes monitoring the radiation levels of the system pre-filters and HEPA filters. These filters are changed out if their radiation level reaches $200 \mathrm{mrem} / \mathrm{h}$.

\subsubsection{Non-Technical Safety Requirement Inspections and Testing}

See HNF-2356.

\subsubsection{Maintenance}

4.3.4.1 Administration Building HVAC System. A brief summary of maintenance activities required for the administration building HVAC system is provided in this section. Additional detail is provided in $\mathrm{HNF}-2356$. 
Filters on heat pump HVAC-HTP-8001 must be changed every six months or more frequently if heavy dust loading occurs. The heat pump manufacturer's recommendations are followed for equipment maintenance.

\subsubsection{Process Bay Recirculation HVAC System}

- All filters are changed based on particulate loading as indicated by the filter differential pressure gauges or the filter radiation level.

- The exhaust fan and motors are maintained (lubricated and belts tightened) per manufacturer's instructions.

\subsubsection{Process Bay Local Exhaust HVAC and Process Vent System}

- All filters are changed based on particulate loading as indicated by the filter differential pressure gauges or the filter radiation level.

- The exhaust fan and motors are maintained (lubricated and belts tightened) per manufacturer's instructions.

4.3.4.4 Process General Supply/Exhaust HVAC System. A brief summary of maintenance activities required for the process general supply/exhaust HVAC system is provided below. Additional detail is provided in HNF-2356.

Pre-filters and HEPA filters are changed based on particulate loading as indicated by filter differential pressure gauges. The fan manufacturer's lubrication instructions as indicated on the fan housing are to be followed.

4.3.4.5 Reference Air System. Dampers and valves are maintained per vendor information.

The atmospheric referenced pipe header is drained of any moisture that may be due to condensation. A drain is installed for this purpose.

The reference air system pressure transmitters/indicators and temperature transmitters are calibrated and/or functionally checked on a periodic basis. The periodic basis is defined per the applicable vendor information. 
SNF-3081 Rev. 0

Appendix A

Source Documents

A-1 
10 CFR 50, "Domestic Licensing of Production and Utilization Facilities," Code of Federal Regulations, as amended.

29 CFR 1910, "Occupational Safety and Health Standards," Section 1910.120, "Hazardous

Waste Operations and Emergency Response," Code of Federal Regulations, as amended.

40 CFR 61,"National Emission Standard for Hazardous Air Pollutants, " Code of Federal Regulations, as amended.

ACGIH, 1998, Industrial Ventilation: Manual of Recommended Practice, 23rd Edition, American Conference of Governmental Industrial Hygienists, Cincinnati, Ohio.

ANSI N13.1, 1993, Guide to Sampling Airborne Radioactive Materials in Nuclear Facilities, American National Standards Institute, New York, New York.

ANSI N512, 1974 (withdrawn/never replaced per ANSI, March 1988), Protective Coatings (Paints) for the Nuclear Industry, American National Standards Institute, New York, New York.

ANSI/ARI 550, 1992, Centrifugal or Rotary Screw Water Chilling Packages, Air Conditioning and Refrigeration Institute, Arlington, Virginia.

ANSI/ARI 590, 1992, Reciprocating Water Chilling Packages, Air Conditioning and Refrigeration Institute, Arlington, Virginia.

ANSI/ASHRAE-52.68, 1995, Method of Testing Air Cleaning Devices Used in General Ventilation for Removing Particulate Material, American Society of Heating, Refrigerating, and Air-Conditioning Engineers, Atlanta, Georgia.

ANSI/ASHRAE-62a, 1991, Ventilation for Acceptable Indoor Air Quality, American Society of Heating, Refrigerating, and Air-Conditioning Engineers, Atlanta, Georgia.

ANSI/ASME AG-1, 1994, Code on Nuclear Air and Gas Treatment, American Society of Mechanical Engineers, New York, New York.

ANSI/ASME B16 Standards series, 1996, Fittings, Flanges and Valves, American Society of Mechanical Engineers, New York, New York.

ANSI/ASME B31.3, 1996, Process Piping Code, American Society of Mechanical Engineers, New York, New York.

ANSI/ASME B31.5, 1995, Refrigerant Piping Code, American Society of Mechanical Engineers, New York, New York.

ANSI/ASME B31.9, 1996, General Services Piping Code, American Society of Mechanical Engineers, New York, New York. 
ANSI/ASME N509, 1996, Nuclear Power Plant Air Cleaning Units and Components, American Society of Mechanical Engineers, New York, New York.

ANSI/ASME N510, 1996, Testing of Nuclear Air Cleaning System, American Society of Mechanical Engineers, New York, New York.

ANSI/ASME NQA-1, 1997, Quality Assurance Requirements for Nuclear Facility Applications, American Society of Mechanical Engineers, New York, New York.

ANSI/AWWA-D100a, 1989, Welded Steel Tanks for Water Storage, American Water Works Association, Denver, Colorado.

ANSI/NFPA 45, 1996, Standard on Fire Protection for Laboratories Using Chemicals, National Fire Protection Association, Quincy, Massachusetts.

ANSI/NFPA 90A, 1996, Standard for the Installation of Air Conditioning and Ventilating Systems, National Fire Protection Association, Quincy, Massachusetts.

ANSI/NFPA 90B, 1996, Standard for the Installation of Warm Air Heating and Air Conditioning Systems, National Fire Protection Association, Quincy, Massachusetts.

ANSI/NFPA 91, 1995, Standard for Exhaust Systems for Air Conveying of Materials, National Fire Protection Association, Quincy, Massachusetts.

ANSI/NFPA 801, 1995, Standard for Facilities Handling Radioactive Materials, National Fire Protection Association, Quincy, Massachusetts.

ASHRAE, 1997, Handbook of Fundamentals, American Society of Heating, Refrigerating, and Air-Conditioning Engineers, Atlanta, Georgia.

ASME, 1995, Boiler and Pressure Vessel Code, American Society of Mechanical Engineers, New York, New York.

ASTM E119, 1995, Fire Tests of Building Construction and Materials, American Society for Testing and Materials, West Conshohocken, Pennsylvania.

ERDA-76-21, 1976, Nuclear Air Cleaning Handbook, Energy Research and Development Administration, Washington, D.C.

SMACNA 1208, HVAC Systems Duct Design, Sheet Metal and Air Conditioning Contractors National Association, Vienna, Virginia.

SMACNA 1481, HVAC Duct Construction Standards - Metal and Flexible, Sheet Metal and Air Conditioning Contractors National Association, Vienna, Virginia. 
UBC, 1994, Uniform Building Code, International Conference of Building Officials, Whittier, California.

WAC 173-400, "General Regulations for Air Pollution Sources," Washington Administrative Code, as amended.

WAC 173-460, "Controls for New Sources of Toxic Air Emissions," Washington Administrative Code, as amended.

WAC 246-247, "Radiation Protection-Air Emissions," Washington Administrative Code, as amended.

DOE Order 5480.1A, "Environmental Protection, Safety, and Health Protection Information Reporting Requirements," U.S. Department of Energy, Washington, D.C.

DOE Order 6430.1A, 1989, General Design Criteria, U.S. Department of Energy, Washington, D.C.

DOE-STD-1020-94, 1994, Natural Phenomena Hazards Design and Evaluation Criteria for Department of Energy Facilities, DOE Standard 1020-94, U.S. Department of Energy, Washington, D.C.

Ecology, 1994, Hanford Federal Facility Agreement and Consent Order, as amended,

Washington State Department of Ecology, U.S. Environmental Protection Agency, and

U.S. Department of Energy, Olympia, Washington.

GH-CLIM-01, 1996, Design Climate Data for the Hanford Site, ICF Kaiser Hanford, Richland, Washington.

HNF-2356, 1999, Spent Nuclear Fuel Project Cold Vacuum Drying Facility Operations Manual, Rev. 1, DE\&S Hanford, Inc., Richland, Washington.

HNF-MP-599, 1997, Project Hanford Quality Assurance Program Description, Rev. 1, Fluor Daniel Hanford, Inc., Richland, Washington.

HNF-SD-SNF-DRD-002, 1999, Cold Vacuum Drying Facility Design Requirements, Rev. 4, Fluor Daniel Hanford, Inc., Richland, Washington.

HNF-SD-SNF-HIE-004, 1998, Cold Vacuum Drying Facility Hazard Analysis Report, Rev. 2, Fluor Daniel Hanford, Inc., Richland, Washington. 
HNF-3553, Annex B, 1999, Safety Analysis Report for the Cold Vacuum Drying Facility, Fluor Daniel Hanford, Inc., Richland, Washington.

HNF-SD-SNF-SEL-002, 1999, Spent Nuclear Fuel Project Cold Vacuum Drying Facility Safety Equipment List, Rev. 6, Fluor Daniel Hanford, Inc., Richland, Washington.

HNF-SD-SNF-TM-004, 1997, Cold Vacuum Drying Process Technical Manual, Rev. 0, Fluor Daniel Hanford, Inc., Richland, Washington.

Merrick, 1996, HVAC Calculations for Project W-441-C1 - Cold Vacuum Drying Facility, Merrick Engineers \& Architects, Los Alamos, New Mexico.

WHC-SD-GN-DGS-30006, 1993, Seismic Design Guide for Safety Class 3 and 4 Equipment at the Hanford Site, Rev. 1, Westinghouse Hanford Company, Richland, Washington.

WHC-SD-SNF-FHA-003, 1996, Preliminary Fire Hazard Analysis for the Cold Vacuum Drying System Facility, Rev. 0, Westinghouse Hanford Company, Richland, Washington.

WHC-SD-SNF-SD-005, 1996, Spent Nuclear Fuel Project Technical Baseline Description, Rev. 1, Westinghouse Hanford Company, Richland, Washington. 
SNF-3081 Rev. 0

Appendix B

System Drawings 
SNF-3081 Rev. 0

\section{DRAWING LIST}

Piping and instrumentation diagrams, flow diagrams, and other drawings applicable to the HVAC systems are listed in Table B-1. The table is provided as a reference for locating drawings. The primary drawing title of all drawings is Cold Vacuum Drying Facility. The secondary title, drawing numbers, and numbers of applicable sheets with each sub-package are as listed in Table B-1. Complete sets of drawings are located with the Spent Nuclear Fuel Project files for the CVD project.

Table B-1. Drawings. (2 sheets)

\begin{tabular}{|c|c|c|c|}
\hline $\begin{array}{l}\text { Drawing } \\
\text { Number }\end{array}$ & $\begin{array}{l}\text { Revision } \\
\text { Number }\end{array}$ & Title & $\begin{array}{l}\text { Sheet } \\
\text { Numbe }\end{array}$ \\
\hline H-1-82191 & 0 & HVAC Abbreviations, Symbols and General Notes & 1 \\
\hline$H-1-82196$ & 0 & HVAC Air Partial Plan Process Bays & 1 \\
\hline H-1-82196 & 0 & HVAC Air Partial Plan Process Bays & 2 \\
\hline $\mathrm{H}-1-82197$ & 0 & HVAC Plan Transfer Corridor & 1 \\
\hline H-1-82198 & 0 & HVAC Plan Mechanical Room & 1 \\
\hline $\mathrm{H}-1-82199$ & 0 & HVAC Plan Administration Area & 1 \\
\hline $\mathrm{H}-1-82200$ & 0 & Chilled Water Piping Plan Mechanical Room & l \\
\hline $\mathrm{H}-1-82202$ & 0 & HVAC Sections & 1 \\
\hline$H-1-82203$ & 0 & HVAC Sections & 1 \\
\hline $\mathrm{H}-1-82207$ & 0 & HVAC P\&ID Facility Instrumentation & 1 \\
\hline $\mathrm{H}-1-82209$ & 0 & HVAC P\&ID Stack Monitoring System & 1 \\
\hline $\mathrm{H}-1-82210$ & 0 & HVAC Equipment Schedule & 1 \\
\hline $\mathrm{H}-1-82210$ & 0 & HVAC Equipment Schedule & 2 \\
\hline$H-1-82211$ & 0 & Exhaust Stack Plan, El., Details and Sections & 1 \\
\hline $\mathrm{H}-1-82212$ & 0 & Exhaust Stack Details and Sections & 1 \\
\hline$H-1-82213$ & 0 & Exhaust Stack Details and Sections & 1 \\
\hline$H-1-82214$ & 0 & Stack Monitoring Exhaust Spool Piece Details & 1 \\
\hline$H-1-82214$ & 0 & Stack Monitoring Shrouded Probe Locations & 2 \\
\hline $\mathrm{H}-1-82214$ & 0 & Stack Monitoring Air Flow/Temperature Loc. & 3 \\
\hline $\mathrm{H}-1-82214$ & 0 & Stack Monitoring Probe Mounting Details & 4 \\
\hline $\mathrm{H}-1-82215$ & 0 & Stack Monitoring Equipment Location & 1 \\
\hline $\mathrm{H}-1-82215$ & 0 & Stack Monitoring Equipment Shelf Details & 2 \\
\hline$H-1-82216$ & 0 & Stack Monitoring Piping Layout & 1 \\
\hline
\end{tabular}


SNF-3081 Rev. 0

\begin{tabular}{|c|c|c|c|}
\hline $\begin{array}{l}\text { Drawing } \\
\text { Number }\end{array}$ & $\begin{array}{l}\text { Revision } \\
\text { Number }\end{array}$ & Title & $\begin{array}{c}\text { Sheet } \\
\text { Number }\end{array}$ \\
\hline$H-1-82216$ & 0 & Stack Monitoring Piping Layout & 2 \\
\hline $\mathrm{H}-1-82216$ & 0 & Stack Monitoring Piping Layout & 3 \\
\hline$H-1-82221$ & 0 & Mechanical Utilities Legend, Schedule, Notes & 1 \\
\hline $\mathrm{H}-\mathrm{I}-82222$ & 0 & Mechanical Utilities Wtr. \& Compressed Gases P\&ID & 1 \\
\hline $\mathrm{H}-1-82222$ & 0 & Mechanical Utilities Compressed \& Instr. Air P\&ID & 2 \\
\hline$H-1-82223$ & 0 & Mechanical Utilities Drainage Systems P\&ID & 1 \\
\hline $\mathrm{H}-1-82225$ & 0 & Mechanical Utilities $]^{\text {st }}$ Floor Drainage Systems & 1 \\
\hline $\mathrm{H}-1-82226$ & 0 & Mechanical Utilities $1^{\text {st }}$ Floor Compressed Gases & 1 \\
\hline $\mathrm{H}-1-82227$ & 0 & Mechanical Utilities $1^{\text {st }}$ Floor Water Systems & 1 \\
\hline $\mathrm{H}-1.82228$ & 0 & Mechanical Utilities $2^{\text {nd }}$ Floor Process Chld. Water & 1 \\
\hline $\mathrm{H}-1-82229$ & 0 & Mechanical Utilities Sections \& Details & 1 \\
\hline $\mathrm{H}-1-82230$ & 0 & Mechanical Utilities Sections \& Details & 1 \\
\hline $\mathrm{H}-1-82231$ & 0 & Mechanical Utilities Hanger Details & 1 \\
\hline
\end{tabular}

\section{SPECIFICATION LIST}

This SDD refers to two sections of the construction specification. These sections are Section 15856, which addresses the HEPA filter housings, and Section 15890, which addresses the ductwork. This information is listed in Table B-2.

Table B-2. Specification List.

\begin{tabular}{|c|l|}
\hline Specification Number & \multicolumn{1}{|c|}{ Title } \\
\hline W-441-C1 & $\begin{array}{l}\text { Cold Vacuum Drying Facility Construction Specification } \\
\text { Section 15856 } \\
\text { Section 15890 }\end{array}$ \\
\hline
\end{tabular}


SNF-3081 Rev. 0

Appendix C

System Procedures

C-1 


$\begin{array}{ll}\text { MP-CVD-016 } & \text { Change Out Process Bay HEPA Filters } \\ \text { MP-CVD-017 } & \text { Inspect General Supply HVAC Equipment } \\ \text { MP-CVD-018 } & \text { Clean and Inspect General Exhaust HVAC Equipment } \\ \text { MP-CVD-019 } & \text { Clean and Inspect Local Exhaust HVAC Equipment } \\ \text { MP-CVD-020 } & \text { Clean and Inspect Process Bay HVAC Equipment } \\ \text { MP-CVD-021 } & \text { Clean and Inspect Administration Building HVAC Equipment } \\ \text { MP-CVD-035 } & \text { Inspect and Test Hood Seals } \\ \text { OP-CVD-028 } & \text { Startup/Shutdown CVD HVAC Systems } \\ \text { SP-CVD-009 } & \text { Calibrate HVAC Instrumentation }\end{array}$

Operation, maintenance and alarm response procedures will be developed. 
SNF-3081 Rev. 0

Appendix D

Miscellaneous Information

D-1 
SNF-3081 Rev. 0

Table D-1. Temperature Transmitters in the Process Bay Local Air Supply Temperature Control Loop.

\begin{tabular}{|c|c|}
\hline Temperature Transmitter & Room \\
\hline TT-8204 & Process bay 2 (room 128) \\
\hline TT-8304 & Process bay 3 (room 125) \\
\hline TT-8404 & Process bay 4 (room 122) \\
\hline TT-8504 & Process bay 5 (room 119) \\
\hline
\end{tabular}


SNF-3081 Rev. 0

Table D-2. Instrumentation Supplied Power by the Electrical Distribution System.

\begin{tabular}{|c|c|}
\hline Instrument & Location \\
\hline TT-8010 & Mechanical room (room 207) \\
\hline TT-8011 & Mechanical room (room 207) \\
\hline TT-8012 & Room 121 (Transfer corridor) \\
\hline TT-8013 & Transfer corridor (room 116) \\
\hline TT-8014 & Process waste water tank room (room 132) \\
\hline PDIT-8070 & Mechanical room (room 207) \\
\hline PDIT-8073 & Room 116 \\
\hline PDIT-8074 & Room 130 \\
\hline PDIT-8075 & Room 127 \\
\hline PDIT-8076 & Room 124 \\
\hline PDIT-8077 & Room 121 \\
\hline PDIT-8078 & Room 118 \\
\hline PDIT-8079 & Room 115 \\
\hline PDIT-8080 & Process waste water tank room (room 132) \\
\hline PDIT-8220 & Process bay 2 (room 128) \\
\hline PDIT -8320 & Process bay 3 (room 125) \\
\hline PDIT-8420 & Process bay 4 (room 122) \\
\hline PDIT-8520 & Process bay 5 (room 119) \\
\hline
\end{tabular}

PDIT $=$ pressure differential indicating transmitter . 
Table D-3. Pressure Transmitter/Indicator Location, Room Design Space Pressure, Alarm Setpoints

\begin{tabular}{|c|c|c|c|}
\hline $\begin{array}{c}\text { Pressure } \\
\text { Transmitter/Indicator }\end{array}$ & Room Number & $\begin{array}{l}\text { Room Design Space } \\
\text { Pressure Relative to } \\
\text { Atmosphere } \\
\text { (in.) }\end{array}$ & $\begin{array}{l}\text { Alarm Setpoints: } \\
\text { High and Low } \\
\text { (in.) }\end{array}$ \\
\hline PDIT-8070 & Mechanical room (room 207) & -0.10 & $\begin{array}{l}\text { High: }-0.05 \\
\text { Low: }-0.15\end{array}$ \\
\hline PDIT-8073 & Room 123 & -0.10 & $\begin{array}{l}\text { High: }-0.05 \\
\text { Low: }-0.15\end{array}$ \\
\hline PDIT-8074 & Room 130 & -0.15 & $\begin{array}{l}\text { High: }-0.10 \\
\text { Low: }-0.20\end{array}$ \\
\hline PDIT-8075 & Room 127 & -0.15 & $\begin{array}{l}\text { High: }-0.10 \\
\text { Low: }-0.20\end{array}$ \\
\hline PDIT-8076 & Room 124 & -0.15 & $\begin{array}{l}\text { High: }-0.10 \\
\text { Low: }-0.20\end{array}$ \\
\hline PDIT-8077 & Room 123 & -0.15 & $\begin{array}{l}\text { High: }-0.10 \\
\text { Low: }-0.20\end{array}$ \\
\hline PDIT-8078 & Room 120 & -0.15 & $\begin{array}{l}\text { High: }-0.10 \\
\text { Low: }-0.20\end{array}$ \\
\hline PDIT-8079 & Room 115 & -0.15 & $\begin{array}{l}\text { High: }-0.10 \\
\text { Low: }-0.20\end{array}$ \\
\hline PDIT-8080 & $\begin{array}{l}\text { Process waste water tank room } \\
\text { (room 132) }\end{array}$ & -0.25 & $\begin{array}{l}\text { High: }-0.20 \\
\text { Low: }-0.30\end{array}$ \\
\hline PDIT-8220 & $\begin{array}{l}\text { Process bay } 2 \\
\text { (room 128) }\end{array}$ & -0.20 & $\begin{array}{l}\text { High: }-0.15 \\
\text { Low: }-0.25\end{array}$ \\
\hline PDIT-8320 & $\begin{array}{l}\text { Process bay } 3 \\
\text { (room 125) }\end{array}$ & -0.20 & $\begin{array}{l}\text { High: }-0.15 \\
\text { Low: }-0.25\end{array}$ \\
\hline PDIT -8420 & $\begin{array}{l}\text { Process bay } 4 \\
\text { (room 122) }\end{array}$ & -0.20 & $\begin{array}{l}\text { High: }-0.15 \\
\text { Low: }-0.25\end{array}$ \\
\hline PDIT -8520 & $\begin{array}{l}\text { Process bay } 5 \\
\text { (room 119) }\end{array}$ & -0.20 & $\begin{array}{l}\text { High: }-0.15 \\
\text { Low: }-0.25\end{array}$ \\
\hline
\end{tabular}

PDIT $=$ pressure differential indicating transmitter. 
SNF-3081 Rev. 0

Table D-4. Temperature Transmitter Setpoints.

\begin{tabular}{|c|c|c|c|}
\hline $\begin{array}{l}\text { Temperature } \\
\text { Transmitter }\end{array}$ & Exhaust System Interface & Room & $\begin{array}{l}\text { Alarm Points: } \\
\text { High and Low } \\
\qquad(\mathrm{C})\end{array}$ \\
\hline TT-8010 & General supply & $\begin{array}{l}\text { Mechanical room } \\
\text { (room 207) }\end{array}$ & $\begin{array}{l}\text { High: } 85 \\
\text { Low: } 72\end{array}$ \\
\hline TT-8011 & General supply & $\begin{array}{l}\text { Mechanical room } \\
\text { (room 207) }\end{array}$ & $\begin{array}{l}\text { High: } 85 \\
\text { Low: } 72\end{array}$ \\
\hline TT-8012 & General supply & Room 121 & $\begin{array}{l}\text { High: } 75 \\
\text { Low: } 72\end{array}$ \\
\hline TT -8013 & General supply & $\begin{array}{l}\text { Transfer corridor } \\
\text { (room 116) }\end{array}$ & $\begin{array}{l}\text { High: } 75 \\
\text { Low: } 72\end{array}$ \\
\hline TT-8014 & General supply & $\begin{array}{l}\text { Process waste water tank } \\
\text { room (room 132) }\end{array}$ & $\begin{array}{l}\text { High: } 75 \\
\text { Low: } 72\end{array}$ \\
\hline TT-8204 & Process bay local & $\begin{array}{l}\text { Process bay } 2 \\
\text { (room } 128 \text { ) }\end{array}$ & $\begin{array}{l}\text { High: } 75 \\
\text { Low: } 72\end{array}$ \\
\hline TT-8304 & Process bay local & $\begin{array}{l}\text { Process bay } 3 \\
\text { (room 125) }\end{array}$ & $\begin{array}{l}\text { High: } 75 \\
\text { Low: } 72\end{array}$ \\
\hline TT-8404 & Process bay local & $\begin{array}{l}\text { Process bay } 4 \\
\text { (room 122) }\end{array}$ & $\begin{array}{l}\text { High: } 75 \\
\text { Low: } 72\end{array}$ \\
\hline TT-8504 & Process bay local & $\begin{array}{l}\text { Process bay } 5 \\
\text { (room 119) }\end{array}$ & $\begin{array}{l}\text { High: } 75 \\
\text { Low: } 72\end{array}$ \\
\hline
\end{tabular}


SNF-3081 Rev. 0

Table D-5. Temperature Transmitters in the General Air Supply Temperature Control Loop.

\begin{tabular}{|c|c|}
\hline Temperature Transmitter & Room \\
\hline TT-8010 & $\begin{array}{c}\text { Mechanical room } \\
\text { (room 207) }\end{array}$ \\
\hline TT-8011 & $\begin{array}{c}\text { Mechanical room } \\
\text { (room 207) }\end{array}$ \\
\hline TT-8012 & Room 121 \\
\hline TT-8013 & $\begin{array}{c}\text { Transfer corridor } \\
\text { (room 116) }\end{array}$ \\
\hline TT-8014 & Process waste water tank room \\
(room 132)
\end{tabular}




\section{DISTRIBUTION SHEET}

\begin{tabular}{|c|c|c|c|c|c|}
\hline \multirow{2}{*}{$\begin{array}{l}\text { To } \\
\text { Distribution }\end{array}$} & \multirow{2}{*}{\multicolumn{3}{|c|}{$\begin{array}{l}\text { From } \\
\text { Technical Integration }\end{array}$}} & \multicolumn{2}{|l|}{ Page 1 of 1} \\
\hline & & & & \multicolumn{2}{|c|}{ Date June 14,1999} \\
\hline \multicolumn{4}{|c|}{ Project Title/Work Order } & \multirow{2}{*}{\multicolumn{2}{|c|}{$\begin{array}{l}\text { EDT No. }-626308,62631 \\
\text { ECN No. NA }\end{array}$}} \\
\hline \multicolumn{4}{|c|}{$\begin{array}{l}\text { SNF-3061, SNF-3066, SNF-3067, SNF-3072, SNF-3073, SNF-3074; } \\
\text { SNF-3077, SNF-3078, SNF-3079, SNF-3080, SNF-3081 }\end{array}$} & & \\
\hline Name & MSIN & $\begin{array}{c}\text { Text } \\
\text { With All } \\
\text { Attach. }\end{array}$ & Text Only & $\begin{array}{l}\text { Attach./ } \\
\text { Appendix } \\
\text { Only }\end{array}$ & $\begin{array}{l}\text { EDT/ECN } \\
\text { Only }\end{array}$ \\
\hline W. C. Alaconis & R3-86 & $\mathrm{X}$ & & & \\
\hline L. L. Blehm & $X 3-86$ & $\mathrm{X}$ & & & \\
\hline K. A. Boes & R3-86 & $\mathrm{X}$ & & & \\
\hline J. R. Brehm & R3-86 & $\mathrm{X}$ & & & \\
\hline C. S. Haller & R3-11 & $\mathrm{X}$ & & & \\
\hline L. C. McKenzie & S2-45 & $\mathrm{X}$ & & & \\
\hline S. L. Mischke & R3-86 & $\mathrm{X}$ & & & \\
\hline C. C. Pitkoff & R3-86 & $\mathrm{X}$ & & & \\
\hline CVD Project File & R3-86 & $\mathrm{X}$ & & & \\
\hline SNF Project File & R3-11 & $\mathrm{x}$ & & & \\
\hline
\end{tabular}

